\title{
DINÂMICA DA RESISTÊNCIA DE Brevipalpus phoenicis (Geijskes, 1939) (ACARI: TENUIPALPIDAE) AO ACARICIDA DICOFOL
}

\author{
EVERALDO BATISTA ALVES
}

Tese apresentada à Escola Superior de Agricultura

“Luiz de Queiroz”, Universidade de São Paulo, para obtenção do título de Doutor em Ciências, Área de Concentração: Entomologia.

P I R A C I C A B A

Estado de São Paulo - Brasil

Fevereiro - 2004 


\title{
DINÂMICA DA RESISTÊNCIA DE Brevipalpus phoenicis (Geijskes, 1939) (ACARI: TENUIPALPIDAE) AO ACARICIDA DICOFOL
}

\section{EVERALDO BATISTA ALVES}

Engenheiro Agrônomo

Orientador: Prof. Dr. CELSO OMOTO

\author{
Tese apresentada à Escola Superior de Agricultura \\ “Luiz de Queiroz”, Universidade de São Paulo, \\ para obtenção do título de Doutor em Ciências, \\ Área de Concentração: Entomologia.
}

P I R A C I C A B A

Estado de São Paulo - Brasil

Fevereiro - 2004 
Dados Internacionais de Catalogação na Publicação (CIP) DIVISÃO DE BIBLIOTECA E DOCUMENTAÇÃO - ESALQ/USP

\section{Alves, Everaldo Batista}

Dinâmica da resistência de Brevipalpus phoenicis (Geijskes, 1939) (Acari :

Tenuipalpidae) a o acarida dic ofol / Everaldo Batista Alves. - - Piracicaba, 2004.

79 p. : il.

Tese (doutorado) - Escola Superior de Agric ultura Luiz de Queiroz, 2004.

Bibliografia.

1. Ácaro-vetor-de-doença-de-planta 2. Fruta cítrica 3. Leprose 4.

Resistência ao acaricida I. Título

CDD 632.6542

"Permitida a cópia total ou parcial deste documento, desde que citada a fonte - $\mathrm{O}$ autor" 
Aos meus pais

Lazaro André e Araci pelo amor, dedicação e exemplo

Dedico...

... Aos meus avós Lazaro Batista e Tereza

e ao meu tio Sérgio

Agradeço. 


\section{AGRADECIMENTOS}

Ao Prof. Dr. Celso Omoto, pela orientação, confiança, amizade e respeito demonstrados durante nosso convívio, além das oportunidades que me foram dadas.

Aos professores do Setor de Entomologia da ESALQ/USP pelos valiosos conhecimentos transmitidos no decorrer do curso.

Aos professores Dr. Sinval Silveira Neto e Dr. Gilberto José de Moraes pelas sugestões dadas para a melhora deste trabalho.

Ao pesquisador Dr. Marcos Antônio Machado pela atenção e por disponibilizar o Laboratório de Biotecnologia do Centro Avançado de Pesquisa Tecnológica do Agronegócio de Citros “Sylvio Moreira” (CAPTACSM) - IAC para a condução de trabalhos de biologia molecular.

À pesquisadora Juliana Freitas-Astúa (EMPRAPA- CAPTACSM) pelo auxílio no trabalho de biologia molecular.

Aos pesquisadores, funcionários e colegas do Centro Avançado de Pesquisa Tecnológica do Agronegócio de Citros “Sylvio Moreira” (CAPTACSM) - IAC pela amizade, companheirismo e colaboração.

À Fundação de Amparo à Pesquisa do Estado de São Paulo - FAPESP pela concessão da bolsa de estudos (Processo: 00/00813-1). 
Ao Fundo Paulista de Defesa da Citricultura - Fundecitrus pelo apoio ao projeto.

À Fischer Agropecuária S.A. e seus engenheiros agrônomos e técnicos pelo apoio ao projeto.

À CitroVita S.A. pela coleta de populações de ácaro-da-leprose.

À estagiária Nádia Fernanda Bertan Casarin pelo companheirismo e serviços prestados no desenvolvimento do projeto.

Aos engenheiros agrônomos e amigos Cláudio R. Franco, Fernando J. Campos, Marcelo Poletti, Roberto H. Konno e Samuel Martinelli pela amizade, companheirismo e colaboração.

Às bibliotecárias Eliana Maria Garcia, Kátia Maria de Andrade Ferraz e Silvia M. Zinsly da ESALQ/USP pelo auxílio e dedicação. 


\section{SUMÁRIO}

Página

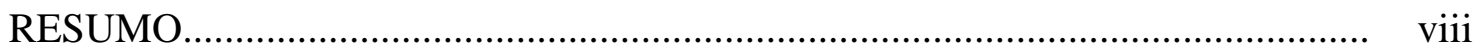

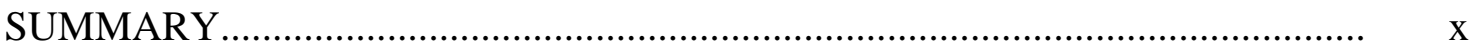

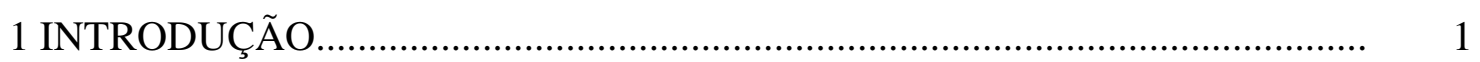

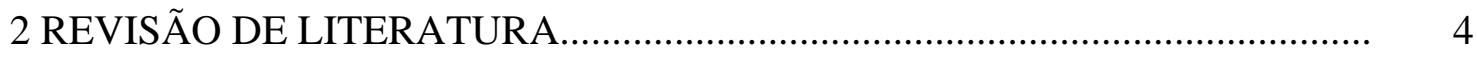

2.1 A magnitude do problema da resistência..................................................... 4

2.2 Resistência de ácaros ao acaricida dicofol.................................................. 5

2.3 Dinâmica da resistência de ácaros ao acaricida dicofol................................... 5

2.3.1 Custo adaptativo associado à resistência..................................................... 6

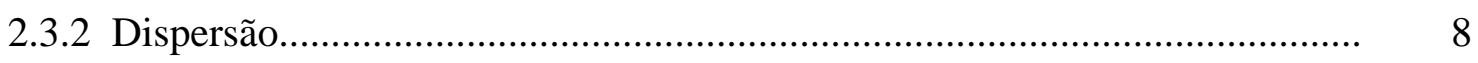

2.3 Implicações para a implementação de estratégias de manejo da resistência..... 11

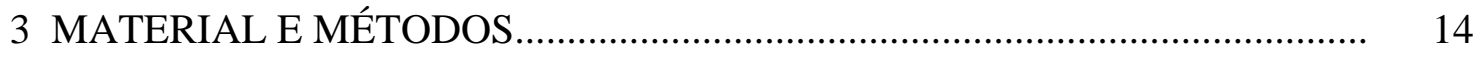

3.1 Dinâmica da resistência de Brevipalpus phoenicis ao dicofol......................... 14

3.2 Dispersão de Brevipalpus phoenicis ........................................................... 18

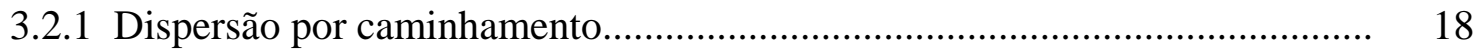

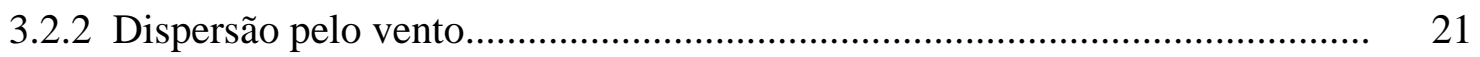

3.3 Freqüência de resistência ao dicofol em populações de Brevipalpus phoenicis coletadas em citros e sansão-do-campo....................................................... 25

3.4 Análise da variabilidade genética através da técnica de RAPD - PCR em populações de Brevipalpus phoenicis coletadas em citros e sansão-do-campo 27

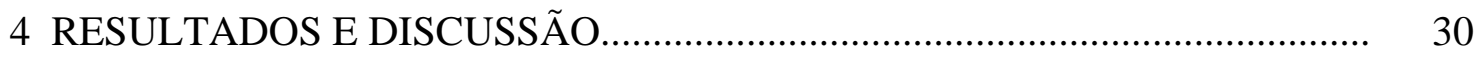

4.1 Dinâmica da resistência de Brevipalpus phoenicis em condições de campo.... 30

4.2 Dispersão de Brevipalpus phoenicis ........................................................... 38

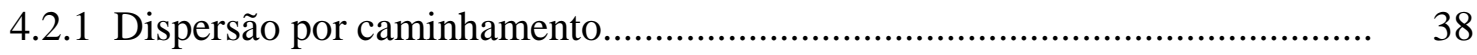

4.2 .2 Dispersão pelo vento....................................................................... 40 
4.3 Freqüência de resistência ao dicofol em populações de Brevipalpus phoenicis coletadas em citros e sansão-do-campo........................................................

4.4 Análise da variabilidade genética através da técnica de RAPD - PCR em populações de Brevipalpus phoenicis coletadas em citros e sansão-do-campo. $\quad 50$

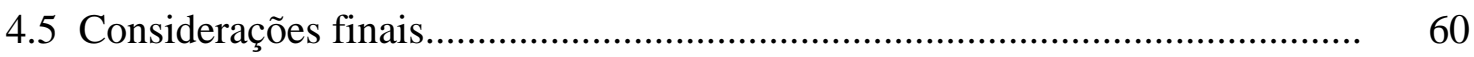

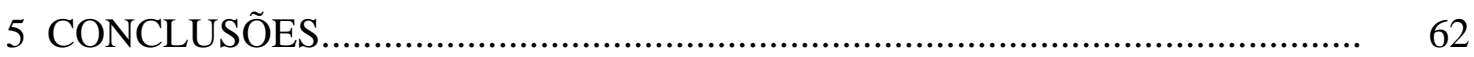

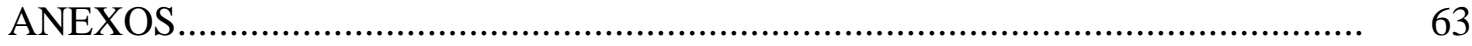

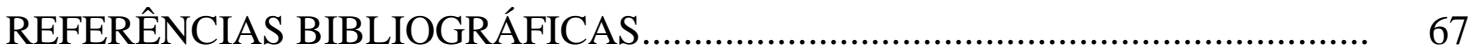




\section{DINÂMICA DA RESISTÊNCIA DE Brevipalpus phoenicis (GEIJSKES, 1939) (ACARI: TENUIPALPIDAE) AO ACARICIDA DICOFOL}

Autor: EVERALDO BATISTA ALVES

Orientador: Prof. Dr. CELSO OMOTO

\section{RESUMO}

O conhecimento da dinâmica da resistência de pragas a pesticidas é de fundamental importância para a implementação de estratégias de manejo da resistência. Desta forma, o principal objetivo do presente trabalho foi estudar a dinâmica da resistência de Brevipalpus phoenicis (Geijskes, 1939) ao acaricida dicofol em pomares comerciais de citros durante um período de aproximadamente três anos. Para tanto, foram realizados estudos para avaliar a resposta à pressão de seleção com dicofol em populações de $B$. phoenicis com diferentes freqüências iniciais de resistência e acompanhamento da freqüência de resistência na ausência de pressão seletiva. Alguns fatores que podem estar envolvidos na dinâmica da resistência de $B$. phoenicis a acaricidas como a capacidade de dispersão e a efetividade de hospedeiros alternativos como refúgio de indivíduos suscetíveis foram avaliados. Aplicações de dicofol em alguns talhões de citros resultaram em aumentos significativos na freqüência de resistência. A velocidade de restabelecimento da suscetibilidade na ausência de pressão seletiva variou entre os talhões. Em alguns talhões, o restabelecimento da suscetibilidade foi observado em um período de aproximadamente um ano. Em outros talhões, o restabelecimento da suscetibilidade não foi observado mesmo após 29 meses sem o uso do dicofol. Trabalhos de dispersão de B. phoenicis conduzidos em casa de vegetação mostraram que a capacidade de dispersão por caminhamento é limitada. Com a liberação de 6.000 ácaros em um determinado ponto, apenas 3\% atingiram distâncias de 40 a 50 
cm. As distâncias percorridas por este ácaro foram geralmente inferiores a $1 \mathrm{~cm} \cdot \mathrm{dia}^{-1}$. Em condições de laboratório, verificou-se que vento de $23 \mathrm{~km} \cdot \mathrm{h}^{-1}$ não foi capaz de arrastar ácaros da superfície de frutos; e velocidades de 30 e $40 \mathrm{~km} . \mathrm{h}^{-1}$ foram capazes de arrastar menos de $1 \%$ da população de ácaros provenientes tanto de colônias novas quanto de colônias velhas. Trabalhos de dispersão em condições de campo mediante a utilização de armadilhas adesivas também comprovaram que a dispersão de B. phoenicis é bastante limitada quando comparada a de outras espécies de ácaros que ocorrem nos pomares de citros. De um total 2.420 e 661 ácaros coletados em dois talhões de citros na região de Descalvado-SP, apenas 0,45 e 11,80\% dos ácaros pertenciam à família Tenuipalpidae, respectivamente. Para verificar a efetividade de outras plantas hospedeiras de $B$. phoenicis como refúgio de indivíduos suscetíveis, a variabilidade genética em populações de $B$. phoenicis provenientes de cercas-vivas de sansão-decampo (Mimosa caesalpiniaefolia Benth.) localizadas próximas aos pomares de citros foi avaliada mediante estimativa da freqüência de resistência ao dicofol e análise molecular. Em geral, a freqüência de resistência em populações de $B$. phoenicis provenientes de sansão-de-campo foi inferior a de citros em um mesmo pomar. No entanto, a análise da variabilidade genética através da técnica de RAPD - PCR mostrou que as populações de $B$. phoenicis provenientes de sansão-do-campo são geneticamente diferentes das populações provenientes de citros. Portanto, baseado nos resultados obtidos conclui-se que o restabelecimento da suscetibilidade de B. phoenicis ao dicofol é bastante variável e a imigração de indivíduos suscetíveis de áreas não tratadas ou de hospedeiros alternativos é bastante limitada. 


\title{
RESISTANCE DYNAMICS OF Brevipalpus phoenicis (GEIJSKES, 1939) (ACARI: TENUIPALPIDAE) TO THE ACARICIDE DICOFOL
}

\author{
Author: EVERALDO BATISTA ALVES \\ Adviser: Prof. Dr. CELSO OMOTO
}

\section{SUMMARY}

The knowledge of dynamics of pest resistance to pesticides is crucial for the implementation of resistance management strategies. Therefore, the main objective of this research was to study the dynamics of the resistance of Brevipalpus phoenicis (Geijskes, 1939) to the acaricide dicofol in commercial citrus groves during a 3-year period. Studies to evaluate the selection response to dicofol were conducted in populations of $B$. phoenicis with different initial resistance frequencies. The frequency of resistance was also estimated in the absence of selection pressure. Some factors that influence the resistance dynamics of B. phoenicis such as the dispersal capacity and the effectiveness of alternative hosts as refuges for susceptible individuals were also evaluated in this study. There was a significant increase in the frequency of dicofol resistance with applications of dicofol in some citrus field plots. The rate of reset to susceptibility in the absence of selection pressure varied from field to field. In some fields, the reset to susceptibility was observed within approximately 12-month period. On the other hand, the reset to susceptibility was not observed even after 29 months without using dicofol. Dispersal studies of B. phoenicis on sandy surface conducted under greenhouse conditions showed that dispersal capacity by crawling is limited. After the release of 6,000 mites in one point, only 3\% reached distances of 40 to $50 \mathrm{~cm}$ from the release point. This mite moved less than $1 \mathrm{~cm} \cdot \mathrm{day}^{-1}$. Wind speed of $23 \mathrm{~km} \cdot \mathrm{h}^{-1}$ was not enough to carry mites from citrus fruit surface under laboratory conditions; and 
wind speeds of 30 and $40 \mathrm{~km} \cdot \mathrm{h}^{-1}$ were capable to carry less than $1 \%$ of mites either from new or old mite colonies on fruits. Mite dispersal studies with the use of sticky traps under field conditions also showed that $B$. phoenicis dispersal is very limited when compared to other mite species that occur in citrus groves. From a total of 2,420 and 661 mites collected from two citrus fields in Descalvado-SP region, only 0.45 and $11.80 \%$ of mites were in the Tenuipalpidae family, respectively. In order to evaluate the effectiveness of other host plants of B. phoenicis as refuges for susceptible individuals, the genetic variability in populations of B. phoenicis from "sansão-de-campo" (Mimosa caesalpiniaefolia Benth.) located near the citrus groves was evaluated by the estimation of resistance frequencies to dicofol and by molecular techniques. In general, the frequency of resistance to dicofol in populations of B. phoenicis from "sansão-decampo" was lower than that from citrus groves. However, the analysis of genetic variability with RAPD-PCR revealed that $B$. phoenicis populations from "sansão-decampo" were genetically different from citrus groves. Based on our results, we concluded that the reset of susceptibility of B. phoenicis to dicofol is very variable and the immigration of susceptible individuals from untreated areas or alternative hosts is very limited. 


\section{INTRODUÇÃO}

As estratégias de manejo da resistência de pragas a pesticidas têm se tornado um componente fundamental dentro dos programas de manejo integrado de pragas (MIP) nos diversos agroecossitemas que utilizam produtos químicos (Duncombe, 1973; National Research Council, 1986; Sawicki \& Denholm, 1987; Forrester, 1990). A implementação destas estratégias não depende apenas da adoção do uso racional dos inseticidas mediante a diminuição, rotação ou mistura de produtos químicos (Georghiou, 1983). O conhecimento de fatores genéticos e bioecológicos ligados à evolução da resistência tem sido fundamental para o desenvolvimento e aperfeiçoamento das estratégias de manejo da resistência. Neste contexto, a estimativa de intervalos mínimos para o restabelecimento da suscetibilidade, avaliação do custo adaptativo associado à resistência, importância das áreas de refúgio para indivíduos suscetíveis e avaliação da capacidade de dispersão do organismo alvo, dentre outros fatores, ajudam a dimensionar as estratégias de manejo da resistência e a entender os sucessos e fracassos das mesmas (Georghiou, 1983; Roush \& Daly, 1990; Omoto et al., 1995).

Os programas de MIP na cultura dos citros no Brasil estão bastante desenvolvidos, sendo que os produtores têm adotado estratégias diversas para o controle das pragas, que vão desde tratos culturais básicos com o manejo adequado de plantas invasoras nas linhas e entre linhas para a preservação de inimigos naturais (Durigan, 1994; Pitelli \& Durigan, 1995) até tecnologias mais avançadas como a utilização de feromônios para o monitoramento de pragas (Bento et al., 2001; Leal et al., 2001) e liberações de inimigos naturais (Chagas et al., 2002). Porém, o controle dos ácaroschave na cultura dos citros, principalmente o ácaro-da-leprose dos citros Brevipalpus phoenicis (Geijskes), ainda envolve o uso de grandes quantidades de acaricidas, em 
especial para o Estado de São Paulo que é responsável por mais de $80 \%$ da produção nacional de laranja (Comenale Neto et al., 1995; FNP Consultoria \& Comércio, 2003). Este fato se deve principalmente por este ácaro ser o transmissor do vírus causador da leprose dos citros, e assim exigir que a população seja mantida em baixas densidades nos pomares (Kitajima et al., 1972; Chiavegato, 1987; Guirado \& Silverio, 1992; Salva \& Massari, 1995; Rodrigues et al., 2003).

Anualmente são gastos aproximadamente 90 milhões de dólares com acaricidas na cultura dos citros, sendo que mais de $80 \%$ desse valor é destinado ao controle do ácaro-da-leprose (Salvo Filho, 1997; Neves et al., 2002). Os acaricidas organoestânicos, dicofol, hexitiazox e propargite são os principais produtos químicos utilizados para o controle deste ácaro. Embora o dicofol esteja no mercado por aproximadamente três décadas, ainda é o segundo produto mais utilizado na citricultura. Este fato se deve principalmente ao seu custo relativamente baixo quando comparado aos demais acaricidas. Desta forma, o dicofol é um produto bastante importante para a citricultura brasileira e deve ser preservado nos programas de manejo da resistência de B. phoenicis a acaricidas (Omoto, 1995).

Casos de desenvolvimento da resistência do ácaro-da-leprose ao acaricida dicofol já foram confirmados e são freqüentes nos pomares de citros do Estado de São Paulo (Gravena, 1994; Omoto, 1998; Alves et al., 1998). Porém, estudos comprovaram que ainda existe uma grande variabilidade com relação à suscetibilidade ao dicofol entre as populações de B. phoenicis provenientes de talhões de citros de um mesmo pomar ou de pomares distintos no Estado de São Paulo (Omoto et al., 2000). Associado a este fato, trabalhos realizados em condições laboratoriais mostraram que a resistência de $B$. phoenicis ao dicofol é instável, ou seja, há uma redução significativa na freqüência de resistência na ausência de pressão de seleção com o dicofol devido ao custo adaptativo associado à resistência (Alves, 1999). A instabilidade da resistência é um dos aspectos que tem sido explorado na implementação de estratégias de manejo da resistência por rotação e mistura de produtos químicos.

Desta forma, o objetivo do presente trabalho foi estudar a dinâmica da resistência do ácaro-da-leprose B. phoenicis ao acaricida dicofol nas principais regiões citrícolas do 
Estado de São Paulo. Fatores bioecológicos considerados importantes para a reversão da resistência como a capacidade de dispersão de B. phoenicis e a efetividade de plantas hospedeiras presentes na periferia dos pomares como refúgio de indivíduos suscetíveis também foram avaliados no presente estudo. Trabalhos de dispersão de B. phoenicis por caminhamento e pelo vento foram conduzidos em condições de laboratório, casa de vegetação e campo. A variabilidade genética em populações de B. phoenicis provenientes de cercas-vivas de sansão-de-campo (Mimosa caesalpiniaefolia Benth.) localizadas próximas aos pomares de citros foi avaliada mediante estimativa da freqüência de resistência ao dicofol e análise molecular, com o objetivo de verificar a similaridade das populações e determinar a importância dos refúgios de B. phoenicis em hospedeiros alternativos para abrigar indivíduos suscetíveis para o manejo da resistência. 


\section{REVISÃO DE LITERATURA}

\subsection{A magnitude do problema da resistência}

Nas últimas décadas a evolução da resistência de pragas a pesticidas tem ganhado destaque em decorrência do aumento na documentação de casos de resistência de ácaros e insetos a pelo menos uma classe de produto químico. No final da década de 80, havia registros de pelo menos 504 espécies de insetos e ácaros resistentes a uma ou mais classes de pesticida, sendo a maior parte das espécies pertencentes à ordem Diptera (35,1\%), seguida pelas ordens Lepidoptera (14,7\%), Coleoptera (14,3\%), Acarina (14\%), Hemiptera-Auchenorrhyncha, Sternorrhyncha (10,1\%) e Hemiptera-Heteroptera (4\%) (Georghiou \& Tejada, 1991). No início do século 21 já havia registros de 540 espécies de insetos e ácaros resistentes (Bills et al., 2004). Observa-se pelos dados apresentados por Georghiou \& Tejada (1991) que o grupo dos ácaros constitui uma parcela significativa dos casos de resistência detectados. Este fato está ligado a fatores genéticos e bioecológicos destes organismos, além da alta pressão de seleção com acaricidas que é imposta para o controle de ácaros em geral.

A evolução da resistência de pragas a pesticidas pode levar ao aumento da dose aplicada, aumento na freqüência das aplicações de pesticidas, uso de misturas indevidas de produtos e substituição do produto ineficiente por uma nova molécula, acarretando assim um aumento no custo de controle, maior destruição de inimigos naturais e maior contaminação do meio ambiente, o que pode levar ao comprometimento dos programas de MIP (Georghiou, 1986). 


\subsection{Resistência de ácaros ao acaricida dicofol}

O acaricida dicofol é um produto análogo do DDT, porém não cumulativo nos organismos vivos e com rápida degradação no meio ambiente (Herne \& Chiba, 1975). Pelo fato do dicofol ter sido utilizado por um período superior a três décadas para controle de ácaros em diferentes culturas, vários casos de resistência a este produto já foram detectados como, por exemplo, em ácaros tetraniquídeos na cultura do algodão (Dennehy \& Granett, 1984a, b), Panonychus ulmi (Koch) e Tetranychus urticae (Koch) em pomares de maçã (Dennehy et al., 1988) e Phyllocoptruta oleivora (Ashmead) em pomares de citros (Omoto et al., 1994) nos Estados Unidos, T. urticae na cultura de rosas na Holanda (Overmeer et al., 1975), ácaros tetraniquídeos em algodão na África (Duncombe, 1973), Panonychus citri (McGregor) em citros no Japão (Inoue, 1980) e Brevipalpus phoenicis (Geijskes) em citros no Brasil (Omoto et al., 2000).

Embora existam vários casos detectados de resistência ao acaricida dicofol, este produto continua sendo um importante componente para os programas de MIP no mundo, devido a sua eficiência no controle de muitas espécies de ácaros fitófagos, baixa toxicidade para alguns organismos benéficos e custo relativamente baixo (Dennehy \& Omoto, 1994). Outro fator para a continuidade de uso do dicofol está associado à instabilidade da resistência para muitas das espécies de ácaros, como por exemplo em $P$. citri (Inoue, 1980), P. oleivora (Omoto et al., 1995), T. urticae (Dennehy et al., 1990) e B. phoenicis (Alves, 1999), o que faz com que este acaricida continue apresentando um bom desempenho no campo ao longo dos anos.

\subsection{Dinâmica da resistência de ácaros ao acaricida dicofol}

A dinâmica da resistência é o estudo das variações na freqüência de resistência ao longo do tempo em uma população de organismo na presença ou ausência de pressão seletiva. Nas situações em que ocorre redução significativa na freqüência de resistência na ausência de pressão de seleção, a resistência é considerada instável; caso contrário, a resistência é considerada estável. A instabilidade da resistência depende de vários 
fatores genéticos, bioecológicos e operacionais (Georghiou \& Taylor, 1977a, b; Dennehy et al., 1990; Roush \& Daly, 1990). Os principais fatores genéticos e bioecológicos que afetam a dinâmica da resistência em campo são o custo adaptativo dos indivíduos resistentes e a imigração de ácaros suscetíveis de áreas não tratadas ou de hospedeiros alternativos para as áreas tratadas com um determinado produto. A dinâmica da resistência não pode ser generalizada para uma determinada espécie e produto, pois esta depende também do ecossistema e do mecanismo de resistência (Roush \& McKenzie, 1987; Roush \& Daly, 1990).

\subsubsection{Custo adaptativo associado à resistência}

A freqüência inicial de alelos resistentes na composição genética de uma determinada praga é estimada entre $10^{-13}$ e $10^{-2}$ (Roush \& McKenzie, 1987). Os indivíduos resistentes permanecem na população numa freqüência mais baixa do que a dos suscetíveis no início da evolução da resistência; caso contrário, os resistentes seriam tão comuns quanto os suscetíveis mesmo antes do uso de um determinado produto (Roush \& McKenzie, 1987; Futuyma, 1992). Porém, com as aplicações constantes de um determinado produto químico, as condições ambientais passam a se tornar desfavoráveis para os indivíduos suscetíveis enquanto que os resistentes sobrevivem e se reproduzem. Linhagens de organismos resistentes a pesticidas freqüentemente são reportadas apresentando desvantagens adaptativas relacionadas a atributos biológicos, porém as linhagens resistentes podem diferir no custo adaptativo por razões independentes da resistência (Roush \& McKenzie, 1987). O custo adaptativo geralmente está associado a fatores que são relevantes à sobrevivência e reprodução da espécie (Roush \& McKenzie, 1987; Roush \& Daly, 1990). Sendo assim, quando um pesticida não é utilizado por um determinado período de tempo, pode-se observar o restabelecimento da suscetibilidade.

A desvantagem adaptativa de indivíduos resistentes em relação aos suscetíveis a um determinado pesticida tem sido uma característica bastante explorada em estratégias de manejo da resistência de pragas a pesticidas. O custo adaptativo associado à 
resistência e a imigração de indivíduos suscetíveis de áreas não tratadas para as tratadas são as condições básicas para o sucesso das estratégias de manejo da resistência de pragas a pesticidas, principalmente para aquelas que preconizam o uso moderado do produto e rotação ou mistura de produtos químicos (Georghiou, 1983; Tabashnik, 1989).

Estudos com algumas espécies de ácaros têm apontado diferenças no valor adaptativo entre os ácaros resistentes e suscetíveis ao dicofol, como por exemplo em $P$. citri no Japão em que as linhagens resistentes ao dicofol apresentaram uma menor taxa de oviposição quando comparado com a da linhagem suscetível (Inoue, 1980). Estudos realizados por Omoto et al. (1995) constataram que a resistência de P. oleivora ao dicofol em condições laboratoriais e de campo era instável, sendo este fato atribuído a possíveis diferenças de custo adaptativo entre as duas linhagens, uma vez que em condições laboratoriais não há fluxo gênico. O custo adaptativo entre linhagens suscetíveis e resistentes ao acaricida dicofol também foi demonstrado em B. phoenicis por Alves (1999), sendo que a linhagem resistente apresentou menor fecundidade e menor longevidade do que a linhagem suscetível.

Por outro lado, estudos realizados por Mable \& Pree (1992) mostraram que não existem diferenças em atributos biológicos entre linhagens suscetível e resistente de $P$. ulmi ao dicofol no Canadá. Estudos de dinâmica da resistência realizados por Dennehy et al. (1990) demonstraram que a resistência de T. urticae ao dicofol na cultura de maçã no Estado de Nova York, Estados Unidos é bastante instável, enquanto que a resistência de P. ulmi se mostrou bastante estável a este mesmo acaricida. Também foi encontrado diferenças de custo adaptativo entre as linhagens suscetível e resistente de $T$. urticae e ausência de custo adaptativo para $P$. ulmi, que poderiam explicar as diferenças de estabilidade da resistência entre as duas espécies. Dennehy et al. (1990) também atribuem a instabilidade da resistência a outros fatores bioecólogicos como a imigração de ácaros suscetíveis de $T$. urticae de outras plantas hospedeiras para os pomares de maçã, enquanto que esta imigração não poderia ser esperada para $P$. ulmi que ataca quase que exclusivamente a macieira. 


\subsubsection{Dispersão}

O conhecimento dos mecanismos de dispersão de organismos também é de grande importância para a compreensão da evolução da resistência a pesticidas (Tabashnik \& Croft, 1982; Taylor \& Georghiou, 1982).

Os ácaros são organismos minúsculos medindo menos de um milímetro e devido a este fato podem ser facilmente carregados pelo vento (Washburn \& Washburn, 1984). Embora os ácaros não possuam asas ou outros aparatos morfológicos, estes podem na maioria das vezes apresentar comportamentos que favorecem sua dispersão. Ácaros da família Tetranychidae apresentam estruturas responsáveis pela produção e confecção de fios de seda. Freqüentemente, aglomerados de ácaros e teias são observados no topo das plantas, sendo este comportamento induzido pela falta de alimento e/ou alta densidade populacional. Através destes aglomerados os ácaros são carregados para outros hospedeiros e campos com maior facilidade por correntes de vento. Outros comportamentos dos ácaros da família Tetranychidae são o chamado "spinning down" que é o ato destes organismos se atirarem da planta e ficarem dependurados por um fio de seda e a confecção de longos e espessos fios de teia onde os ácaros ficam aderidos esperando que uma corrente de vento faça com que sejam carregados (Gerson, 1985; Kennedy \& Smitley, 1985). O comportamento de distensão do corpo na posição vertical e contra correntes de vento são observados para os ácaros da família Eriophyidae. Nault \& Styer (1969) observaram que correntes de vento induziam o ácaro Aceria tulipae (Keifer) a ficar na posição vertical e formar "correntes" de indivíduos. Bergh \& McCoy (1997) relataram que o ácaro da falsa ferrugem $P$. oleivora pode ficar na posição vertical e se lançar do substrato para aproveitarem a corrente de vento.

A dispersão por caminhamento também é relatada entre os ácaros da família Tetranychidae, sendo mais comumente utilizada para pequenas distâncias entre as plantas vizinhas (Kennedy \& Smitley, 1985). Este mecanismo de dispersão pode exercer influência significativa na infestação inicial das culturas. Trabalho realizado por Brandenburg \& Kennedy (1982) mostraram a capacidade de caminhamento de T. urticae e que este mecanismo de dispersão constitui um dos principais componentes da 
infestação de plantações de milho por $T$. urticae provenientes de plantas hospedeiras deste ácaro na periferia dos campos de cultivo. Já entre os ácaros predadores da família phytoseiidae, a dispersão por caminhamento é mais comum. Porém, mesmo com sua agilidade, apenas pequenas distâncias são percorridas, sendo incapazes de serem significativas para infestar campos distantes. Comportamentos de dispersão aérea foram observados para o ácaro predador Metaseiulus occidentalis (Nesbitt). Hoy et al. (1984) descreveram que na ausência de alimento estes ácaros apresentam o comportamento de distender as pernas anteriores e posicionar o corpo na vertical e apoiados pelas pernas posteriores quando submetidos a correntes fracas e moderadas de vento.

Estudos de dinâmica da resistência realizados por Dennehy et al. (1990) mostraram que a resistência de T. urticae ao dicofol na cultura da maçã no Estado de Nova York, Estados Unidos é bastante instável, enquanto que a resistência de P. ulmi se mostrou bastante estável a este acaricida. Os autores explicaram esses resultados através da possibilidade de imigração de T. urticae suscetíveis de outras plantas hospedeiras presentes na periferia do pomar que não recebem aplicações de produtos químicos, enquanto que esta imigração não poderia ser esperada para $P$. ulmi que ataca quase que exclusivamente a cultura da maçã. No entanto, Lawson et al. (1996) mostraram em seu trabalho que $P$. ulmi em pomares comerciais de maçã se dispersava com facilidade mesmo quando a densidade populacional era baixa e a injúria provocada não era visível. Este fato também pode ser explicado por estudos realizados por Overmeer et al. (1975) que verificaram que a resistência de $T$. urticae ao dicofol se mostrava bastante estável durante vários anos em condições de casa de vegetação na Holanda, uma vez que dentro deste ambiente não ocorria a presença de refúgio para abrigar populações suscetíveis de T. urticae que poderiam diluir a freqüência de resistência das populações presentes na cultura.

O ácaro-da-leprose $B$. phoenicis também é uma espécie polífaga e cosmopolita, sendo encontrado na África, Ásia, Austrália, Europa, América do Norte, América do Sul e ilhas do Pacífico (Haramoto, 1969). Associado a sua ampla distribuição está o grande número de plantas hospedeiras deste ácaro. Pritchard \& Baker, citados por Childers et al. (2001), relatam que até 1958 tinham sido descritas 63 plantas hospedeiras de $B$. 
phoenicis. Atualmente, segundo Ochoa et al., citados por Childers et al. (2001), na América Central foram descritas 114 plantas hospedeiras de B. phoenicis. Reis (1974) em sua revisão relata a existência de 37 frutíferas de clima tropical e subtropical atacadas por B. phoenicis no Brasil. E segundo Chiavegato \& Mischan (1987), mais de 80 gêneros de plantas têm sido relatados como hospedeiros desse ácaro, destacando o citros como o principal hospedeiro. Por sua vez, Trindade \& Chiavegato (1994) encontraram 34 hospedeiros desta praga entre plantas cultivadas, ornamentais e invasoras de pomares cítricos no Estado de São Paulo. Trabalhos realizados por Maia \& Oliveira (2002) identificaram plantas hospedeiras potenciais para o desenvolvimento de populações de B. phoenicis presentes nos pomares de citros como a cerca-viva Mimosa caesalpiniaefolia Benth. e plantas invasoras como Bidens pilosa L.

O hábito alimentar polífago de $B$. phoenicis e a presença de várias plantas hospedeiras dentro e na periferia dos pomares de citros que abrigariam populações suscetíveis deste ácaro são apontados como um dos principais fatores impedindo ou retardando que a evolução da resistência de $B$. phoenicis aos acaricidas se torne crítica nos pomares de citros do Estado de São Paulo (Omoto, 1998). No entanto, ao contrário de outras espécies de ácaros, B. phoenicis apresenta comportamento bastante sedentário se escondendo em frestas e saliências ocasionadas pela doença verrugose provocada pelo fungo Elsinoe fawcetti Bitancourt \& Jenkins em frutos e ramos das plantas de citros (Chiavegato, 1986; Nakano et al., 1987). Trabalho realizado por Rodrigues (2002) para verificar a dinâmica da doença leprose em um pomar de citros, mostrou que o crescimento da doença leprose é maior no sentido da linha do que nas entre linhas, sugerindo que devido às distâncias das plantas serem menores na linha os ácaros poderiam atingir estas plantas com maior facilidade. Porém, os mecanismos de dispersão são desconhecidos para B. phoenicis.

A influência da dispersão na dinâmica da resistência em ácaros é relativa e pode ser considerada mínima quando comparada a pragas com alta capacidade de dispersão, como é o caso de insetos da ordem Lepidoptera. Porém, quando se compara entre e dentro das famílias de ácaros constata-se que esta influência é significativa para a dinâmica da resistência (Dunley \& Croft, 1992). Hoy et al. (1984) estudaram a 
dispersão de tetraniquídeos dentro de plantações de amêndoas e Grafton-Cardewell et al. (1991) estudaram a dispersão de ácaros tetraniquídeos entre plantações vizinhas de amêndoas e de algodão localizadas no Vale de São Joaquim na Califórnia, Estados Unidos. Estes autores verificaram que a freqüência de resistência para cada espécie de ácaro estudada era similar nas culturas vizinhas, mesmo recebendo pulverizações com acaricidas distintos. Os autores comprovaram através do uso de armadilhas adesivas colocadas entre as culturas que estes resultados eram decorrentes da alta taxa de dispersão destes ácaros de uma cultura para outra ocasionada por fatores como estresse hídrico das plantas e aplicações de acaricidas repelentes.

A instabilidade da resistência de $P$. oleivora ao acaricida dicofol verificada em condições de campo por Omoto et al. (1995) nos pomares de citros da Flórida também foi atribuída em parte à dispersão aérea deste ácaro entre plantações de citros (Bergh \&

McCoy, 1997; Bergh, 2001). Estes autores demonstraram por meio de uso de armadilhas adesivas que $P$. oleivora se dispersa com grande facilidade entre os pomares. Adultos de P. oleivora foram capturados a uma distância de 135 metros dos pomares de citros infestados.

\subsection{Implicações para a implementação de estratégias de manejo da resistência}

As estratégias de manejo da resistência de pragas a pesticidas são divididas em três categorias: manejo por moderação, manejo por saturação e manejo por ataque múltiplo (Georghiou, 1983). Estratégias de manejo da resistência por moderação têm como premissa o uso menos freqüente de produtos químicos mediante a adoção de táticas alternativas de controle (Georghiou, 1983). Como exemplo, na cultura dos citros existe grande preocupação com a preservação de fungos entomopatogênicos e ácaros predadores com o objetivo de diminuir o uso de acaricidas (Reis et al., 1998; Alves et al., 2000c; Poletti, 2002). Outra estratégia de moderação tem sido a adoção do controle do ácaro-da-leprose em reboleiras com o objetivo de diminuir a pressão de seleção e permitir que indivíduos suscetíveis de outras partes do pomar possam sobreviver e diluir 
a freqüência de resistência. Esta última estratégia tem sido adotada também com o objetivo de diminuir os custos de controle.

As estratégias por saturação objetivam saturar o mecanismo de resistência mediante a utilização de altas doses para que a resistência seja funcionalmente recessiva ou mediante uso de sinergistas (Georghiou, 1983). Como B. phoenicis é um ácaro haplóide (Helle et al., 1980; Pijnacker et al., 1980), a dominância funcional da resistência não pode ser controlada.

As estratégias de ataque múltiplo têm como premissa a utilização de acaricidas com mecanismos de ação distintos, sendo estes produtos químicos liberados no ambiente mediante a rotação ou mistura de acaricidas. A rotação de acaricidas tem sido largamente difundida e utilizada entre os produtores de citros em virtude da facilidade de implementação e menor custo quando comparado com a mistura de produtos. Embora, a mistura de acaricidas seja bastante comum no controle do ácaro-da-leprose, várias limitações podem ser apontadas para o seu uso na citricultura, como por exemplo a falta de estudos que comprovem sua eficiência para o manejo da resistência de B. phoenicis e estudos básicos de compatibilidade e persistência dos produtos utilizados. Outro fator importante para o sucesso das misturas para o manejo da resistência é que a freqüência de resistência para cada um dos produtos utilizados em mistura deve ser extremamente baixa (Mani, 1985; Comins, 1986), fato este que não é observado para a maioria dos produtos utilizados em mistura na citricultura brasileira (Alves et al., 2000b).

Relações de resistência cruzada entre os produtos utilizados em rotação também devem ser avaliadas para o sucesso das estratégias de manejo da resistência. Trabalhos realizados por Fergusson-Kolmes et al. (1991) mostraram a importância dos estudos de resistência cruzada para a implementação das estratégias de manejo da resistência para o ácaro T. urticae em diversas culturas nos Estados Unidos. Estes autores verificaram que para o manejo da resistência de T. urticae ao dicofol, os acaricidas bromopropilato, amitraz e clorobenzilato não deveriam ser utilizados em rotação com o dicofol. Alves et al. (2000a) também comprovaram a resistência cruzada positiva entre o acaricida dicofol e o bromopropilato para B. phoenicis. O uso de produtos que apresentam resistência cruzada pode comprometer as estratégias de manejo da resistência. 
Para todas as estratégias de manejo da resistência, o conhecimento da dinâmica da resistência é de fundamental importância para a implementação, refinamento e compreensão de seus sucessos e fracassos em um ecossistema (Roush \& Mckenzie, 1987; McKenzie, 1996). Trabalho realizado por Omoto et al. (1995) mostraram a importância do conhecimento da dinâmica da resistência em condições de campo. Estes autores estimaram um intervalo mínimo de restabelecimento da suscetibilidade de $P$. oleivora ao acaricida dicofol nos pomares de citros da Flórida nos Estados Unidos. O intervalo mínimo de restabelecimento da suscetibilidade (IMR) corresponde ao período mínimo entre uma aplicação e outra de um mesmo produto, permitindo que a freqüência de indivíduos resistentes diminua a níveis anteriores ao da aplicação do produto (Georghiou, 1983; National Research Council, 1986; Dennehy et al., 1990; Omoto et al., 1995). Se um determinado produto (ou outros produtos com resistência cruzada) é utilizado em um intervalo menor que o IMR, a freqüência de resistência pode aumentar no sistema escalonado, comprometendo assim a vida útil do produto devido à resistência. 


\section{MATERIAL E MÉTODOS}

\subsection{Dinâmica da resistência de Brevipalpus phoenicis ao dicofol}

Os estudos de dinâmica da resistência de $B$. phoenicis ao dicofol foram realizados em talhões de citros de pomares comerciais da empresa Fischer Agropecuária S.A. localizados nas regiões de Araraquara e Barretos no Estado de São Paulo, nos anos de 2001 a 2003. A identificação dos talhões avaliados, número de plantas no talhão e respectivas localidades encontram-se no Quadro 1 e na Figura 1. Os regimes de uso de acaricidas nestes talhões antes e durante a condução do trabalho estão apresentados no Anexo A.

\begin{tabular}{|ccll|}
\hline Identificação & No de plantas/talhão & \multicolumn{1}{c|}{ Local } & \multicolumn{1}{c|}{ Propriedade } \\
\hline ARA-1 & 2.000 & Boa Esperança do Sul & Faz. Entre Rios \\
ARA-2 & 2.500 & Gavião Peixoto & Faz. São Carlos \\
ARA-3 & 5.000 & Boa Esperança do Sul & Faz. Entre Rios \\
ARA-4 & 2.500 & Gavião Peixoto & Faz. São Carlos \\
BAR-1 & 11.000 & Barretos & Faz. Barreiro Grande \\
BAR-2 & 11.000 & Barretos & Faz. Barreiro Grande \\
BAR-3 & 2.500 & Onda Verde & Faz. São João \\
BAR-4 & 6.800 & Onda Verde & Faz. São João \\
\hline
\end{tabular}

Quadro 1- Identificação, número de plantas por talhão de citros, local e propriedade das populações de Brevipalpus phoenicis avaliadas no estudo de dinâmica da resistência ao acaricida dicofol 


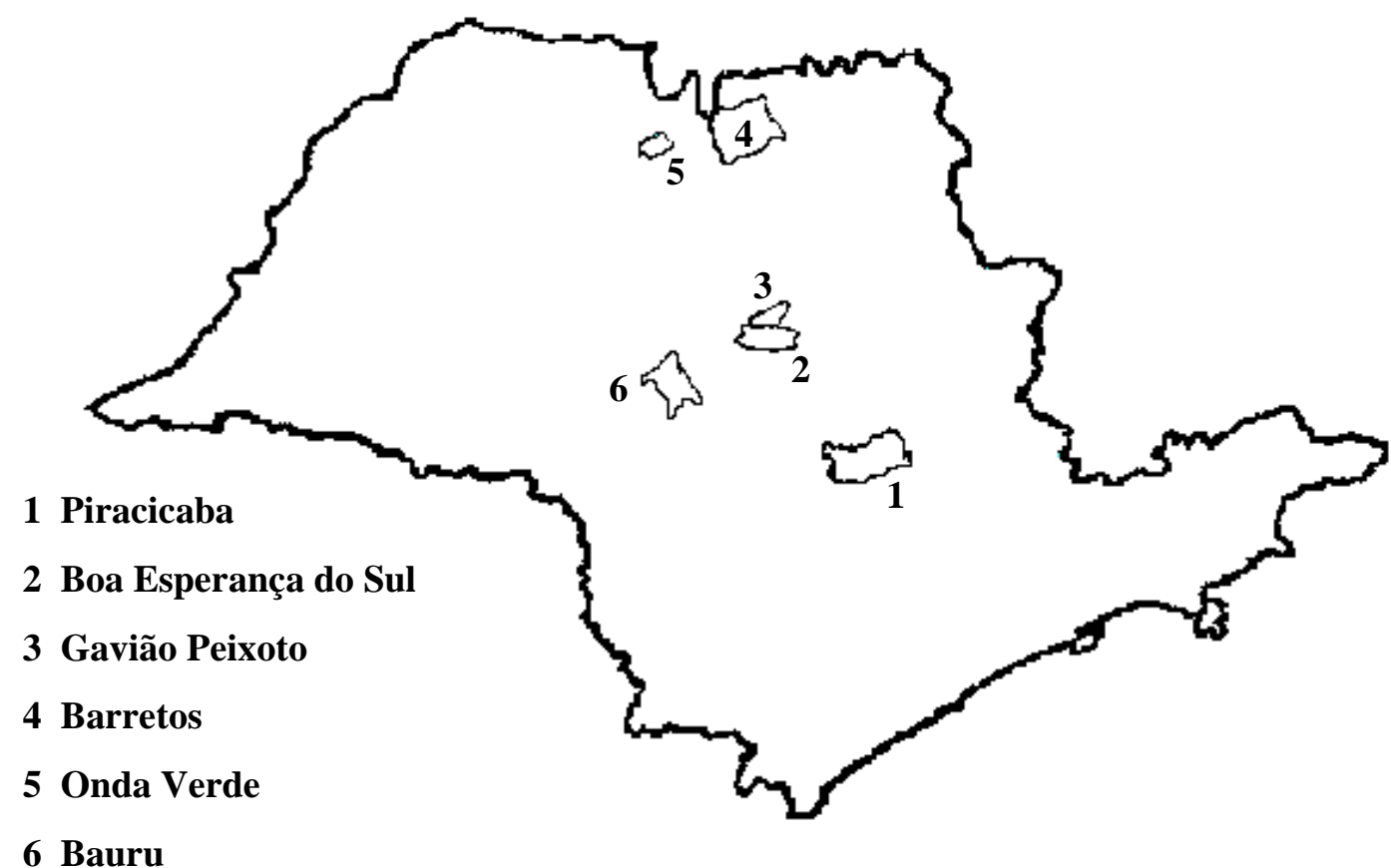

Figura 1 - Regiões de coleta de Brevipalpus phoenicis para estudos de dinâmica da resistência, freqüência de resistência entre hospedeiros e análise da variabilidade genética deste ácaro coletado em Mimosa caesapiniaefolia e Citrus sinensis

Para a estimativa da freqüência de resistência de B. phoenicis ao acaricida dicofol em cada talhão de citros utilizado no trabalho, foram coletados aproximadamente 50 frutos com ácaros-da-leprose em diferentes pontos do talhão de um pomar de citros para serem levados ao Laboratório de Resistência de Artrópodes a Pesticidas da ESALQ/USP para a multiplicação dos ácaros. A quantidade de ácaros coletada para cada população variou de 150 a 400 ácaros. Adultos de B. phoenicis foram retirados do material coletado e multiplicados em frutos de laranja das variedades Pera Rio ou Valência parafinados e apresentando uma arena de aproximadamente 8 a $16 \mathrm{~cm}^{2}$ delimitada por cola adesiva (Tanglefoot ${ }^{\circledR}$, Grand Rapids, MI, Estados Unidos) para confinar os ácaros. 
Em cada fruto foram transferidos de 40 a 50 ácaros com auxílio de um pincel com apenas um pêlo e dois microscópios estereoscópicos. Os frutos infestados com os ácaros foram colocados em caixas plásticas (dimensões de 41 x 34 x $14 \mathrm{~cm}$ ) contendo em seu fundo uma prancha de isopor com 12 orifícios onde os frutos eram acondicionados. A criação foi mantida em sala climatizada à temperatura de $25 \pm 2{ }^{\circ} \mathrm{C}$, umidade relativa ao redor de $70 \%$ e fotofase de 14 horas. Os frutos foram renovados a cada 30 ou 40 dias mediante a sobreposição da arena do fruto novo sobre a arena do fruto infestado com os ácaros, para que estes se movimentassem para o fruto novo.

Após a criação de B. phoenicis por pelo menos uma geração no laboratório, a estimativa da freqüência de resistência ao dicofol foi realizada utilizando método de bioensaio de contato residual com a concentração discriminatória de $32 \mathrm{mg}$ de dicofol por litro de água destilada (ppm [I.A.] de dicofol), seguindo metodologia apresentada nos trabalhos de Alves (1999) e Omoto et al. (2000). O produto comercial utilizado foi o Kelthane $480^{\circledR}$ CE (480 g de dicofol por litro de produto comercial, formulação concentrado emulsionável, Dow Agrociences Ltda). Arenas de 2,6 cm de diâmetro confeccionadas com folhas de laranjeira da variedade Pera Rio foram utilizadas no trabalho. A aplicação do produto foi feita sobre a superfície adaxial dos discos de folha mediante o uso da torre de pulverização de Potter (Burkard Manufacturing, Rickmansworth, Herts, Reino Unido) calibrada à pressão de 10 psi (68,95 kPa). Foi pulverizado um volume de $2 \mathrm{~mL}$ de solução em cada aplicação para obtenção de uma deposição média de resíduo úmido de $1,56 \mathrm{mg} \cdot \mathrm{cm}^{-2}$ sobre as arenas. Após a secagem do produto, as arenas foram acondicionadas individualmente em placas acrílicas de 3,5 cm de diâmetro (Falcon 1008, Becton Dickinson Labware, Lincoln Park, NJ, Estados Unidos) contendo $2 \mathrm{~mL}$ de uma mistura ainda não geleificada de ágar-água na concentração de aproximadamente 2\%. Após a geleificação do substrato no fundo da placa, uma barreira para evitar a fuga dos ácaros foi construída ao redor dos discos de folha com a mesma mistura de ágar-água.

Foram transferidos 10 ácaros adultos por arena de bioensaio. Após a infestação dos ácaros nas arenas, as placas foram tampadas e mantidas em câmara climatizada à temperatura de $25 \pm 1{ }^{\circ} \mathrm{C}$, umidade relativa de $70 \pm 10 \%$ e fotofase de 14 horas. A 
mortalidade foi avaliada 24 horas após a infestação com o auxílio de um pincel com um único pêlo e microscópio estereoscópico. Os ácaros foram virados de costas e aqueles que retornaram à posição normal e andaram foram considerados vivos. A estimativa da freqüência de resistência para cada população estudada foi obtida utilizando aproximadamente 160 ácaros adultos divididos em quatro bioensaios realizados ao longo do tempo. As repetições que apresentaram uma mortalidade superior a $15 \%$ na testemunha foram descartadas, assim como aquelas cuja perda de ácaros no ágar ultrapassou $15 \%$.

Para verificar a resposta à pressão seletiva com dicofol em condições de campo, este produto foi aplicado nos talhões ARA-1, ARA-2, BAR-1 e BAR-2 na dose de $360 \mathrm{~g}$ de I.A / 1.000 L de água com pulverizador atomizador de 2.000 L. Posteriormente estes talhões não receberam a aplicação de dicofol até o final do experimento. Já nos talhões ARA-3, ARA-4, BAR-3 e BAR-4 que apresentaram alta frequiência inicial de resistência, estes foram mantidos na ausência de pressão seletiva no decorrer do experimento. Produtos que não apresentavam resistência cruzada com o dicofol foram utilizados durante o período de 2001 a 2003 para manter a densidade populacional de $B$. phoenicis abaixo do nível de dano econômico (Anexo A). As coletas de populações de B. phoenicis para a estimativa da frequiência de resistência no decorrer do tempo em cada talhão foram realizadas de acordo com a densidade populacional do ácaro-daleprose, sendo que foram feitas de uma a duas coletas em cada talhão de citros por ano.

Os dados proporcionais de freqüência de resistência $(X)$ obtidos para cada repetição foram transformados para arcsen $\sqrt{(\mathrm{x} / 100)}$ para serem submetidos à análise de variância. A resposta à pressão de seleção com dicofol foi avaliada pelo teste $t$ unilateral, pela comparação da estimativa da freqüência de resistência antes e após a pressão de seleção. Apenas uma análise descritiva foi realizada para avaliar as mudanças na freqüência de resistência na ausência de pressão seletiva, sendo que a comparação entre dois valores de freqüência de resistência de datas de amostragem de interesse foi realizada pelo teste $t$ unilateral. O nível de significância dos testes foi de $\alpha$ $=0,05$. 


\subsection{Dispersão de Brevipalpus phoenicis}

\subsubsection{Dispersão por caminhamento}

Para verificar a dispersão por caminhamento, os experimentos foram conduzidos em uma casa de vegetação localizada no Setor de Entomologia da Escola Superior de Agricultura "Luiz de Queiroz" em Piracicaba-SP em condições não controladas de temperatura e umidade e sem a incidência direta de raios solares, no período de outubro a fevereiro de 2001 a 2003. A população de B. phoenicis (BAR-2) proveniente do pomar da Fazenda Barreiro Grande de propriedade da Empresa Fischer Agropecuária S.A. localizado em Barretos - SP foi utilizada neste estudo. Para tanto, esta população foi inicialmente multiplicada sobre folhas de feijão-de-porco (Canavalia ensiformis L.) acondicionadas em bandejas plásticas com 20 cm de diâmetro, contendo uma camada de esponja embebida em água. As bordas das folhas foram circundadas com algodão

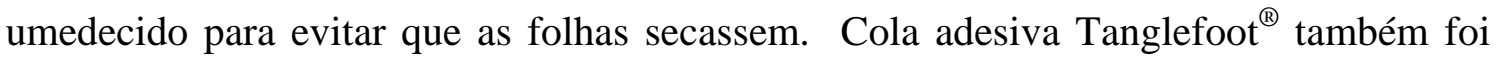
utilizada para delimitar a arena de criação neste substrato. Aproximadamente 20 arenas de feijão-de-porco foram mantidas em sala climatizada à temperatura de $25 \pm 2{ }^{\circ} \mathrm{C}$, umidade relativa ao redor de $70 \%$ e fotofase de 14 horas. As arenas eram renovadas quinzenalmente ou até que houvesse a necessidade de material novo para os ácaros se alimentarem. Os ácaros das arenas velhas eram transferidos recortando as arenas em partes menores que eram colocadas por cima das arenas novas.

A superfície utilizada para o caminhamento de B. phoenicis foi areia média fina espalhada sobre um substrato para o cultivo de hortaliças (Plantimax Hortaliça HA) com aproximadamente $10 \mathrm{~cm}$ de espessura. Um número definido de 16 plantas de $C$. ensiformis não infestadas por B. phoenicis foram plantadas circularmente neste substrato para cada distância de caminhamento a ser avaliada. As distâncias de 10, 20, 30, 40 e 50 cm foram avaliadas por meio de círculos não sobrepostos formados por plantas de $C$. ensiformis e com raios de mesmo comprimento das distâncias a serem avaliadas (Figura 2). 
Folhas de C. ensiformis infestadas com B. phoenicis mantidas na criação foram recortadas em arenas de aproximadamente $2 \mathrm{~cm}$ de diâmetro. Posteriormente, o número de ácaros foi contado com o auxílio de um microscópio estereoscópico e as arenas foram colocadas no centro de cada círculo. O experimento foi repetido seis vezes ao longo do tempo para cada distância avaliada. Aproximadamente 1.000 ácaros adultos foram liberados em cada repetição e a avaliação foi realizada sete dias após a liberação. A avaliação dos ácaros que atingiram o alvo foi feita cortando-se as plantas de $C$. ensiformis e examinando-as com o auxílio de um microscópio estereocópico. O número de ácaros capturados foi transformado em porcentagem de recaptura $(X)$ em função do número de ácaros adultos liberados.

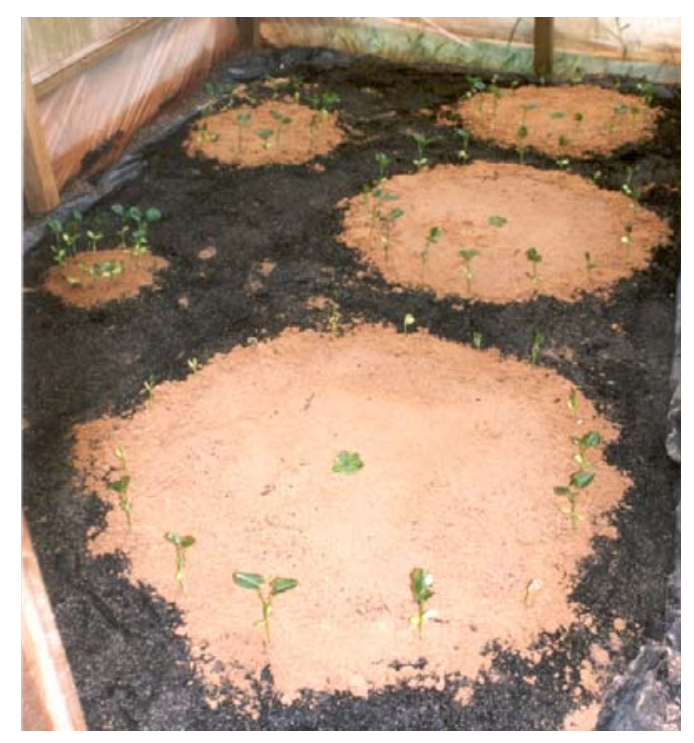

Figura 2 - Experimento em casa de vegetação para verificar a capacidade de dispersão por caminhamento de Brevipalpus phoenicis. Círculos com raios de 10, 20, 30, 40 e $50 \mathrm{~cm}$ formados por Canavalia ensiformis plantadas na periferia; e no centro partes de folhas da planta infestadas com o ácaro

A taxa de dispersão representada pela distância e área percorrida por um organismo durante um intervalo de tempo também foi avaliada para o ácaro-da-leprose através de uma metodologia semelhante ao experimento anterior. Para tanto, $C$. ensiformis foram plantadas individualmente em recipientes de $100 \mathrm{~mL}$ e dispostas em 
círculos concêntricos seguindo metodologia de Dobzansky \& Wright ${ }^{1}$, citados por Silveira Neto et al. (1976). O círculo central possuía $5 \mathrm{~cm}$ de raio e os demais círculos concêntricos possuíam raios de 15, 25, 35 e $45 \mathrm{~cm}$. As plantas de C. ensiformis foram distribuídas proporcionalmente ao tamanho de cada círculo e um total de 46 pontos de captura foram utilizados (Figura 3).

Foram realizadas duas repetições ao longo do tempo e aproximadamente 3.000 ácaros adultos foram liberados no círculo central em cada repetição. A avaliação dos ácaros que atingiram as plantas de $C$. ensiformis foi realizada retirando os recipientes contendo as plantas e transportando-os para averiguação em laboratório após 24 horas da retirada. Avaliações foram realizadas diariamente onde novas plantas eram colocadas nas posições originais, a cada avaliação. O experimento foi conduzido por um período de sete dias, a partir do qual não se registrou mais ácaros capturados em nenhuma das plantas.

A taxa de dispersão foi avaliada através do número de ácaros coletados nas armadilhas de cada círculo, utilizando-se as fórmulas de $\mathrm{S}^{2}$ e DM que representam, respectivamente, a área e distância percorrida pelo ácaro num determinado tempo. Os componentes descritos nas fórmulas são a distância de cada círculo em relação ao centro do anel (r), número de armadilhas em cada círculo (a), número total de ácaros coletados em cada círculo (i) e média de ácaros (total de ácaros/número de armadilhas) no círculo central (C).

$$
\mathbf{S}^{2}=\frac{\sum \mathbf{r}^{3} * \mathbf{i} / \mathbf{a}}{\Sigma(\mathbf{r} * \mathbf{i} / \mathbf{a})+\mathrm{C} / 2 \pi} \quad \mathbf{D M}=\frac{\sum \mathbf{r}^{2} * \mathbf{i} / \mathbf{a}}{\Sigma(\mathbf{r} * \mathbf{i} / \mathbf{a})+\mathrm{C} / 2 \pi}
$$

\footnotetext{
${ }^{1}$ DOBZHANSKY. T.; WRIGHT, S. Genetics of natural populations. X. Dispersion rates in Drosophila pseudoobscura. Genetics, v. 28, p. 304-340, 1943.
} 


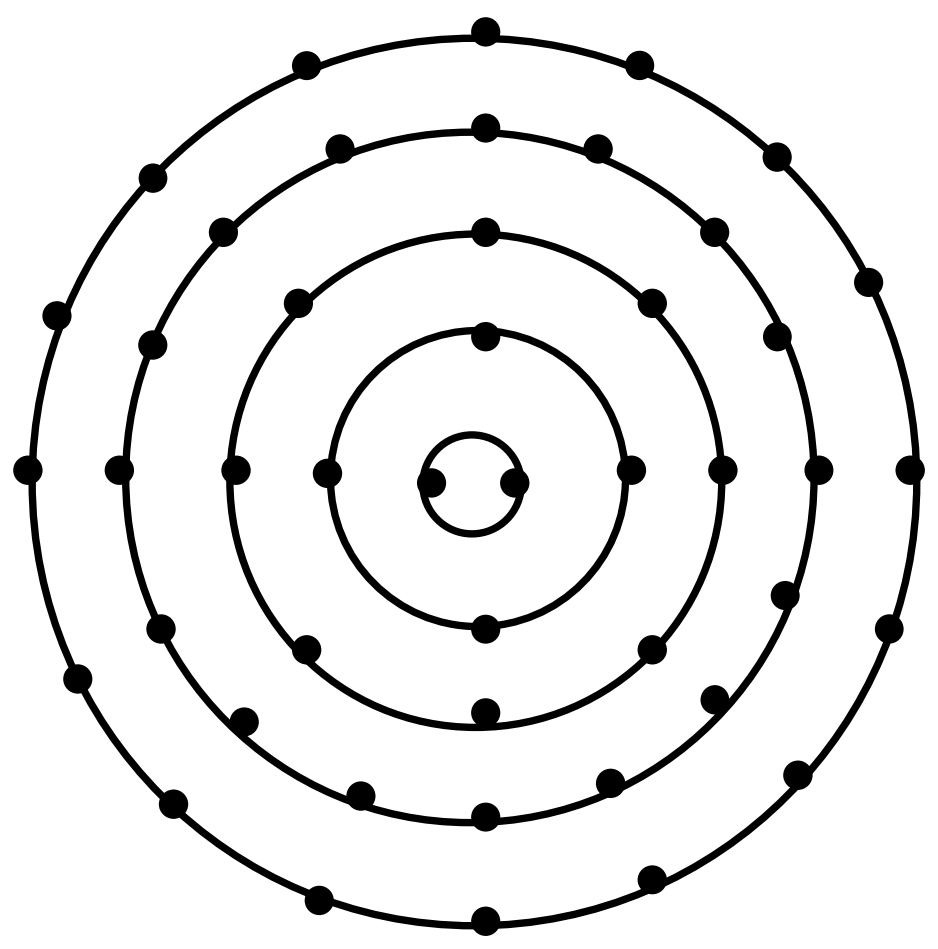

ESCALA $1: 5$

Figura 3 - Número e posicionamento de plantas de Canavalia ensiformis em círculos concêntricos para estimativa da taxa de dispersão de Brevipalpus phoenicis pelo método de Dobzansky \& Wright, citados por Silveira Neto et al. (1976)

\subsubsection{Dispersão pelo vento}

\section{Estudo de Laboratório}

O experimento foi conduzido no Laboratório de Resistência de Artrópodes a Pesticidas da Escola Superior de Agricultura "Luiz de Queiroz" à temperatura de $25 \pm 2$ ${ }^{\circ} \mathrm{C}$ e umidade relativa de $70 \pm 10 \%$. As diferentes velocidades de vento foram produzidas com um ventilador com ajustes de velocidade e variando a distância entre o ventilador e as colônias de B. phoenicis expostas as correntes de vento, obtendo-se velocidades de aproximadamente 23, 30 e $40 \mathrm{~km} \cdot \mathrm{h}^{-1}$ registradas por um anemômetro da marca R. Fuess ${ }^{\circledR}$ (Berlin Steglitz). Estas velocidades foram testadas sobre colônias de $B$. 
phoenicis para verificar a eficiência do vento na capacidade de arraste deste ácaro da superfície de frutos de citros. A corrente de vento foi forçada a passar por um corredor com dimensões de $35 \mathrm{~cm}$ de largura x $45 \mathrm{~cm}$ de altura e frutos de laranja da variedade Pera Rio provenientes da criação de B. phoenicis com colônias novas deste ácaro foram posicionadas contra as correntes de vento. As colônias de ácaros foram posicionadas tangencialmente à corrente de vento e a $15 \mathrm{~cm}$ de distância do fruto foi colocado um anteparo de papelão revestido de polietileno (dimensões de 15 x $15 \mathrm{~cm}$ ) com cola adesiva Tanglefoot ${ }^{\circledR}$ para a coleta dos ácaros que se desprenderam do fruto. De três a cinco colônias de B. phoenicis com quantidades de ácaros adultos variando de 200 a 1.000 foram utilizadas para cada velocidade do vento. O tempo de exposição das colônias de B. phoenicis para cada velocidade de vento avaliada foi de 30 e 60 minutos.

A condição de estresse resultante das colônias de B. phoenicis estarem se alimentando sobre um mesmo local durante muito tempo também foi avaliada na dispersão de B. phoenicis pelo vento. Colônias novas recentemente estabelecidas em frutos e colônias velhas apresentando sinais de fuga de ácaros da arena de criação no fruto foram expostas a correntes de vento de $30 \mathrm{~km} \cdot \mathrm{h}^{-1}$. O número de ácaros nos dois tipos de colônia de B. phoenicis variou de 200 a 1.000.

Apenas os ácaros vivos capturados na cola do anteparo foram considerados. O número de ácaros capturados foi transformado em porcentagem de captura $(X)$ em função do número de ácaros adultos presentes em cada fruto e transformados usando arcsen $\sqrt{(\mathrm{x} / 100)}$ para serem submetidos à análise de variância de dois fatores (velocidade e tempo de exposição) com interação. O nível de significância dos testes foi de $\alpha=0,05$.

\section{Estudo de Campo}

A dispersão aérea foi estudada em dois talhões de citros situados em extremidades opostas de um pomar pertencente à empresa Fischer Agropecuária S. A. localizado em Descalvado-SP. Os dois talhões de citros (identificados como A e B) estavam distanciados entre si por aproximadamente $3 \mathrm{~km}$ e eram cercados em um de 
seus quadrantes por uma mata com plantas nativas da região como o "Capixingui" (Croton floribundus Spreng.; Euphorbiaceae) onde foi encontrado grande quantidade de B. phoenicis, os demais quadrantes dos talhões de citros eram cercados por outros talhões de citros. No talhão $\mathrm{A}$, a dispersão aérea foi avaliada no período de maio a dezembro de 2001 e no talhão B ela foi avaliada durante o período de maio de 2001 a setembro de 2002. A porcentagem de infestação de B. phoenicis nos citros também foi registrada durante este período, através de avaliações realizadas pela Empresa Fischer Agropecuária S.A. As avaliações de infestação foram realizadas uma a duas vezes por mês em cada talhão, seguindo método de amostragem seqüencial.

Armadilhas com dimensões de 15 x 15 cm confeccionadas com papelão revestido de polietileno contendo em um dos lados cola adesiva Tanglefoot ${ }^{\circledR}$ para captura de insetos foram posicionadas para a captura de ácaros no sentido da linha e entre as linhas de citros a 0,9; 1,5 e 2,1 m de altura e a aproximadamente 1,5; 15 e 45 metros da periferia para o interior dos pomares no quadrante próximo a mata. Em cada área foram colocadas 108 armadilhas, divididas em três linhas distanciadas por aproximadamente 15 m (Figura 4).
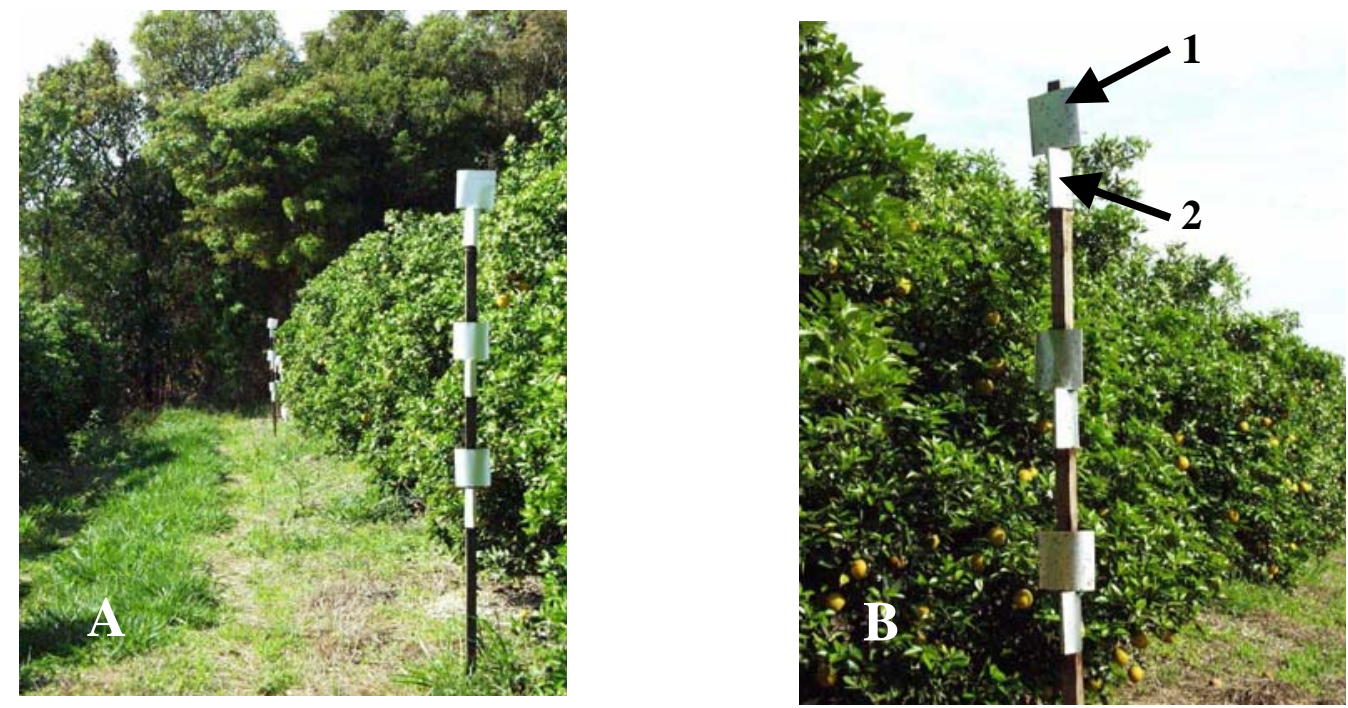

Figura 4 - A) Armadilhas adesivas posicionadas no interior do talhão de citros. B) Detalhe do posicionamento das armadilhas para a captura de Brevipalpus phoenicis no sentido da linha (1) e entre as linhas (2) de citros. 
A dispersão aérea de $B$. phoenicis ao redor de pomares também foi estudada através do posicionamento de armadilhas em dois quadrantes externos do talhão B e em um pomar da Escola Superior de Agricultura "Luiz de Queiroz" em Piracicaba-SP. No talhão B as armadilhas foram posicionadas entre os citros e uma mata e entre os citros e outro talhão. Na Escola Superior de Agricultura "Luiz de Queiroz" as armadilhas foram posicionadas entre o pomar de citros e uma cerca-viva de sansão-do-campo (Mimosa caesalpiniaefolia Benth.). As armadilhas foram posicionadas a 1,5 m da periferia dos pomares e direcionadas para o pomar e para fora do pomar a 0,9; 1,5 e 2,1 m de altura. Em cada quadrante foram colocadas 24 armadilhas divididas em quatro pontos de amostragem. As armadilhas foram mantidas de junho a dezembro de 2002.

A cada 15 dias aproximadamente as armadilhas eram substituídas por novas e levadas ao laboratório para serem avaliadas com o auxílio de um estereoscópio. Nas armadilhas posicionadas no interior dos talhões A e B, ácaros das famílias Tenuipalpidae, Tetranychidae e Phytoseiidae foram registrados enquanto que apenas ácaros da família Tenuipalpidae foram registrados para as armadilhas posicionadas na periferia do pomar. Os ácaros aderidos à cola adesiva foram retirados das armadilhas utilizando querosene para dissolver a cola e com o auxílio de um pincel. Posteriormente os ácaros foram montados em lâminas permanentes de microscópio utilizando meio de Hoyer. A identificação taxonômica destes ácaros foi realizada com o auxílio de um microscópio de contraste de fases, com aumento de até 100 vezes.

O número total de ácaros das famílias Tenuipalpidae, Tetranychidae e Phytoseiidae coletados foram transformados em porcentagem e uma análise descritiva foi realizada entre as três famílias de ácaros. Para estudar a influência do posicionamento das armadilhas adesivas em relação as linhas de citros; as alturas de 0,9; 1,5 e 2,1 m; e a distância das armadilhas em relação à periferia do pomar, o número de ácaros coletados ao longo do período de avaliação do experimento foram agrupados, sendo que cada linha de armadilhas constituiu uma repetição. Os ácaros coletados no talhão A foram agrupados nas respectivas linhas do talhão $\mathrm{B}$, devido ao reduzido número de $B$. phoenicis coletados naquele talhão. Os dados de posicionamento das armadilhas, altura das armadilhas e distância das armadilhas em relação a periferia do 
pomar foram submetidos à análise de variância e as médias comparadas pelo teste de Tukey. O nível de significância foi de 0,05. Uma análise descritiva do número de $B$. phoenicis coletados ao longo do período de avaliação para os dois talhões de citros estudados também foi realizada.

\subsection{Freqüência de resistência ao dicofol em populações de Brevipalpus phoenicis coletadas em citros e sansão-do-campo}

Populações de B. phoenicis foram coletadas em citros (Citrus sinensis (L.)) e na cerca-viva formada por sansão-do-campo (Mimosa caesalpiniaefolia Benth.) plantadas aproximadamente a 10 metros de distância dos pomares. Populações de B. phoenicis foram coletadas em pomares de Piracicaba (ESALQ), em pomares da Empresa Fischer Agropecuária S. A. de Boa Esperança do Sul (ER-1, ER-2 e ER-3), Gavião Peixoto (MAR-1 e MAR-2), Barretos (BG-1, BG-2 e BG-3) e Onda Verde (SJ-1 e SJ-2) e em pomares da Empresa CitroVita S.A. de Bauru (VEN-1 e VEN-2) (Figura 1, Quadro 2). As populações foram coletadas em citros e sansão-do-campo na mesma época para eliminar o efeito do tempo nas diferenças de freqüência de resistência ao acaricida dicofol entre os dois hospedeiros. As coletas de B. phoenicis foram realizadas pelo menos um ano após a última aplicação de dicofol em cada talhão.

A coleta de ácaros nos citros foi realizada em frutos com o auxílio de uma lupa de bolso e a coleta de B. phoenicis realizada em sansão-do-campo foi feita através da amostragem aleatória de ramos da planta. A quantidade de ácaros coletada para cada população variou de 150 a 400 . No laboratório, adultos de B. phoenicis de ambos os hospedeiros foram retirados dos materiais coletados e mantidos em frutos de laranja das variedades Pera Rio ou Valência para serem criados por pelo menos uma geração para eliminar possíveis efeitos de variações nutricionais entre os hospedeiros e variações ambientais que poderiam influenciar a freqüência de resistência de B. phoenicis ao acaricida dicofol. O método de criação adotado está descrito no item 3.1. 


\begin{tabular}{|lll|}
\hline Identificação & Local & Propriedade \\
\hline ESALQ & Piracicaba & ESALQ \\
ER-1 & Boa Esperança do Sul & Faz. Entre Rios \\
ER-2 & Boa Esperança do Sul & Faz. Entre Rios \\
ER-3 & Boa Esperança do Sul & Faz. Entre Rios \\
MAR-1 & Gavião Peixoto & Faz. Maringá \\
MAR-2 & Gavião Peixoto & Faz. Maringá \\
BG-1 & Barretos & Faz. Barreiro Grande \\
BG-2 & Barretos & Faz. Barreiro Grande \\
BG-3 & Barretos & Faz. Barreiro Grande \\
SJ-1 & Onda Verde & Faz. São João \\
SJ-2 & Onda Verde & Faz. São João \\
VEN-1 & Bauru & Faz. Ventura \\
VEN-2 & Bauru & Faz. Ventura \\
\hline
\end{tabular}

Quadro 2 - Identificação, local e propriedade das populações de Brevipalpus phoenicis coletadas em citros e em sansão-do-campo para comparação da variabilidade genética

Para a estimativa da freqüência de resistência foi utilizado bioensaio de contato residual utilizando-se uma concentração discriminatória de 32 ppm de dicofol, conforme descrito no item 3.1. A estimativa média da freqüência de resistência para cada população estudada foi obtida utilizando-se aproximadamente 200 ácaros adultos divididos em cinco bioensaios realizados ao longo do tempo.

Os dados proporcionais de freqüência de resistência $(X)$ obtidos para cada repetição foram transformados para arcsen $\sqrt{(\mathrm{x} / 100)}$ e submetidos a um teste $t$ unilateral para verificar se a freqüência de resistência das populações de $B$. phoenicis coletadas em sansão-do-campo eram significativamente inferiores à freqüência de 
resistência das populações coletadas em citros. O nível de significância do teste foi de $\alpha$ $=0,05$.

\subsection{Análise da variabilidade genética através da técnica de RAPD-PCR em populações de Brevipalpus phoenicis coletadas em citros e sansão-do-campo}

O trabalho foi realizado no Laboratório de Biotecnologia do Centro Avançado de Pesquisa Tecnológica do Agronegócio de Citros “Sylvio Moreira” (CAPTACSM) - IAC em Cordeirópolis-SP. Doze populações de B. phoenicis coletadas em pomares de citros (Citrus sinensis (L.)) e sansão-do-campo (Mimosa caesalpiniaefolia Benth.) plantadas

aproximadamente a 10 metros destes pomares foram utilizadas para verificar a similaridade genética das mesmas através da técnica de DNA polimórfico amplificado ao acaso (RAPD-PCR). Populações de B. phoenicis das regiões de Piracicaba (ESALQ), Boa Esperança do Sul (ER-1), Gavião Peixoto (MAR-1), Barretos (BG-1), Onda Verde (SJ-1) e Bauru (VEN-1) no Estado de São Paulo (Figura 1; Quadro 2) foram coletadas e criadas em laboratório seguindo metodologia apresentada nos itens 3.1 e 3.3. As populações de $B$. phoenicis de citros e sansão-do-campo das localidades de Boa Esperança do Sul, Barretos e Bauru foram utilizadas para encontrar iniciadores que apresentassem polimorfismo e consequentemente pudessem ser testados nas demais populações estudadas.

O método de extração de DNA de B. phoenicis utilizado foi uma modificação daquele apresentado por Rodrigues (2000) onde 500 ácaros foram transferidos para um tubo de plástico de $500 \mu \mathrm{L}$ e macerados com bastão de vidro. Em seguida, $100 \mu \mathrm{L}$ de tampão de extração (10 mM de Tris, pH 7,5; 0,5 \% de SDS; 1 mM de $\mathrm{CaCl}_{2} ; 50$ ng. $\mu \mathrm{L}^{-1}$ de proteinase K) foram acrescentados ao macerado, o qual foi acondicionado em estufa a $37{ }^{\circ} \mathrm{C}$ por 3 horas. Após este período o material foi centrifugado por 30 segundos a 12.000 rpm e o sobrenadante coletado e acondicionado em outro tubo de plástico com $100 \mu \mathrm{L}$ de água milli-Q e 1 volume de clorofórmio : álcool isoamílico (24 : 1) para serem submetidos a centrifugação por 8 minutos a $12.000 \mathrm{rpm}$. O sobrenadante foi coletado e armazenado em tubo de plástico, 1 volume de fenol foi adicionado e nova 
centrifugação de 8 minutos a $12.000 \mathrm{rpm}$ foi realizada. Ao sobrenadante obtido foi adicionado novamente 1 volume de clorofórmio : álcool isoamílico (24:1) e após nova centrifugação de 8 minutos o sobrenadante foi transferido para um tubo de plástico e o volume completado para $100 \mu \mathrm{L}$ com água milli-Q. Em seguida foram adicionados 4 $\mu \mathrm{L}$ de $\mathrm{NaCl} 5 \mathrm{M}, 200 \mu \mathrm{L}$ de etanol gelado e o material foi armazenado em freezer a - 20 ${ }^{\circ} \mathrm{C}$ por um período de 12 horas. Após esse período, procedeu-se com uma centrifugação por 15 minutos a $12.000 \mathrm{rpm}$. O sobrenadante foi eliminado e $100 \mu \mathrm{L}$ de etanol $70 \%$ gelado foram adicionados para a realização de uma nova centrifugação a 12.000 rpm por 7 minutos. Após esta centrifugação o sobrenadante foi descartado e o precipitado foi seco em temperatura ambiente, ressuspendido em água milli-Q e armazenado em freezer a $-20{ }^{\circ} \mathrm{C}$.

Foram avaliados 75 iniciadores curtos de 10 bases (decâmeros) da Operon Technologies, Alabama, CA para detectar a presença de polimorfismo entre as populações, sendo que os iniciadores A5: 5'-AGGGGTCTTG-3', A10: 5'GTGATCGCAG-3', C5: 5'-GATGACCGCC-3', C15: 5'-GACGGATCAG-3', E11: 5'GAGTCTCAGG-3', E14: 5'-TGCGGCTGAG-3', E18: 5'-GGACTGCAGA-3', G2: 5'GGCACTGAGG-3'， G3: 5'-GAGCCCTCCA-3' e G15: 5'-ACTGGGACTC-3' apresentaram polimorfismo e foram escolhidos para serem testados em todas as populações avaliadas. Ao menos duas repetições de DNA provenientes de amostras distintas de cada população avaliada foram utilizadas para cada iniciador avaliado.

Em cada reação de amplificação $2 \mu \mathrm{L}$ de DNA; 2,5 $\mu \mathrm{L}$ de tampão 10X PCR Buffer; $1 \mu \mathrm{L}$ de $\mathrm{MgCl}_{2} 50 \mathrm{mM}$; 0,5 $\mu \mathrm{L}$ de dNTP $10 \mathrm{mM}$; 2,5 $\mu \mathrm{L}$ de primer (5 ng de

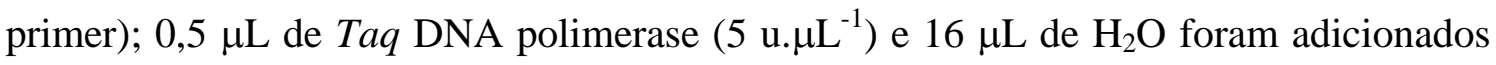
em tubo de plástico de $0,2 \mathrm{~mL}$ acrescido de uma gota de óleo mineral para evitar evaporação. A amplificação foi feita em um termociclador Mastercycler (Eppendorf) com os seguintes passos: (a) $92{ }^{\circ} \mathrm{C}, 1$ min.; (b) $36{ }^{\circ} \mathrm{C}, 1$ min.; (c) $72{ }^{\circ} \mathrm{C}, 2$ min.; (d) retorno para (a) 50 vezes e (e) $72{ }^{\circ} \mathrm{C}$ por $10 \mathrm{~min}$. Os produtos da amplificação foram separados por eletroforese em gel de agarose a 1,5\% preparado em TAE 1X (0,04 M Tris-acetato; 0,001 M EDTA) contendo 0,5 $\mu \mathrm{g} \cdot \mathrm{mL}^{-1}$ de brometo de etídio. A 
visualização das bandas foi feita com o auxílio de luz UV e o registro, por meio de fotodocumentação utilizando-se o aparelho Eagle Eye II (Stratagene).

Bandas correspondentes à amplificação de DNA foram diretamente registradas para todos os iniciadores como presentes ou ausentes (valores 1 e 0 , respectivamente) para as 12 populações avaliadas. Apenas bandas visíveis, reproduzíveis e compreendidas entre 500 e 2.000 pares de bases foram incluídas na análise. A análise consistiu na elaboração de uma matriz de similaridade que foi avaliada pelo programa POPGENE (Versão 1.32, Francis C. Yeh, University of Alberta, Canadá http://www.ualberta.ca/ fyeh/index.htm) seguindo metodologia descrita por Nei (1973). Uma vez que os marcadores RAPD são dominantes e ácaros B. phoenicis são haplóides, utilizou-se essas opções no menu do programa. A identidade genética e distância genética foram calculadas entre as 12 populações avaliadas. Valores médios de diversidade genética total $(\mathrm{Ht})$, diversidade genética intrapopulacional (Hs) e coeficiente de diferenciação gênica (Gst) e número e porcentagem de loci polimórficos foram calculados entre e dentro das sub populações de B. phoenicis coletadas nos hospedeiros citros e sansão-do-campo. Um dendrograma foi calculado usando o método UPGMA "Unweighted pair-group method with arithmetic mean" (Baumann et al., 2003).

Análise molecular da variância (AMOVA) também foi calculada através do software WINAMOVA 1.55 (http://gb.unige.ch/software/win/amova/) (Excoffier et al., 1992). Esta análise é baseada no princípio da análise clássica de variância e foi conduzida utilizando uma matriz de distância Euclidiana entre todos os pares de haplótipos para estimar quanto da variação do RAPD entre e dentro das populações foi decorrente do efeito da população (Coletta-Filho \& Machado, 2002). Componentes da variância foram estimados baseando-se na proporção da variância total atribuído ao efeito do nível da população ( $\phi$ STAT). Os componentes da variância e valores de $\phi$ STAT foram testados estatisticamente por testes randômicos não paramétricos com 1.000 repetições, usando a hipótese de variação nula das amostras do erro amostral ao acaso na construção das populações. 


\section{RESULTADOS E DISCUSSÃO}

\subsection{Dinâmica da resistência de Brevipalpus phoenicis em condições de campo}

A aplicação de dicofol em 2001 nos talhões ARA-1, ARA-2 (Figura 5), BAR-1 e BAR-2 (Figura 6) das regiões de Araraquara e Barretos-SP, respectivamente, resultaram em aumentos significativos na freqüência de resistência de B. phoenicis ao dicofol (Tabela 1). No presente estudo, freqüências de resistência superiores a 80\% foram obtidas alguns meses após a aplicação do dicofol. A rápida evolução da resistência tem a influência direta do modo de reprodução do ácaro-da-leprose que é do tipo partenogênese telítoca automítica (Helle et al., 1980; Weeks et al., 2001), sendo assim, as fêmeas selecionadas para resistência dão origem apenas a fêmeas resistentes.

Após a aplicação do dicofol, as variações nas freqüências de resistência no decorrer do tempo apresentaram comportamento distinto para os talhões de citros avaliados. A dinâmica da resistência de B. phoenicis ao acaricida dicofol nos talhões de citros avaliados na região de Araraquara apresentou um comportamento mais estável do que a dinâmica da resistência avaliada em talhões de citros da região de Barretos. As diferenças entre as freqüências de resistência dos monitoramentos realizados logo após a aplicação do dicofol no ano de 2001 e o último monitoramento da freqüência de resistência realizado em agosto ou setembro do ano de 2003 foram significativas e de aproximadamente $11 \%(t=6,08 ; P=0,0089)$ e $23 \%(t=4,11 ; P=0,0146)$ para os talhões ARA-1 e ARA-2, respectivamente. Porém, as freqüências de resistência ao final do experimento foram significativamente superiores àquelas estimadas no início do experimento antes da aplicação do dicofol (ARA-1: $t=12,69 ; P=0,0011$; ARA-2: $t=$ 4,58; $P=0,0196)$. Desta forma, períodos de 24 e 29 meses após a aplicação do dicofol 
não foram suficientes para o restabelecimento da suscetibilidade a níveis abaixo da freqüência de resistência inicial, antes da aplicação do produto, para os talhões ARA-1 e ARA-2, respectivamente.

Na região de Barretos as diferenças encontradas entre as freqüências de resistência estimadas logo após a aplicação do dicofol e o último monitoramento do ano de 2003 foram de $72 \%$ ( $t=23,44 ; P=0,0002)$ e $41 \%(t=7,00 ; P=0,006)$ para os talhões BAR-1 e BAR-2, respectivamente. As freqüências de resistência ao final do experimento foram significativamente inferiores à freqüência de resistência inicial antes da aplicação do dicofol para o talhão BAR-1 $(t=13,99 ; P=0,0008)$ e igual para o talhão BAR-2 ( $t=0,28 ; P=0,7983)$; e os intervalos de tempo para que a freqüência de resistência restabelecesse a níveis abaixo ou igual a freqüência de resistência antes da aplicação do dicofol foram de 13 e 29 meses, respectivamente.

Tabela 1. Identificação das populações de Brevipalpus phoenicis, freqüência de resistência ( \pm erro padrão da média) antes e após a aplicação de dicofol

\begin{tabular}{ccccc}
\hline \multirow{2}{*}{ Identificação } & \multicolumn{2}{c}{$\begin{array}{c}\text { Freqüência de resistência ao dicofol } \\
\mathbf{( \% )} \pm \mathbf{E P M}\end{array}$} & Valor de $\boldsymbol{t}^{*}$ & Probabilidade \\
& Antes da aplicação & Após a aplicação & & \\
\hline ARA-1 & $24,19 \pm 2,65$ & $97,00 \pm 2,25$ & 10,36 & 0,0019 \\
ARA-2 & $30,43 \pm 3,65$ & $75,74 \pm 3,64$ & 7,62 & 0,0047 \\
BAR-1 & $49,38 \pm 4,25$ & $80,88 \pm 2,66$ & 19,35 & 0,0003 \\
BAR-2 & $16,35 \pm 3,16$ & $58,49 \pm 5,62$ & 4,87 & 0,0165 \\
\hline * valores de $t$ estimados através de teste unilateral para avaliar a resposta à pressão de \\
seleção com dicofol
\end{tabular}



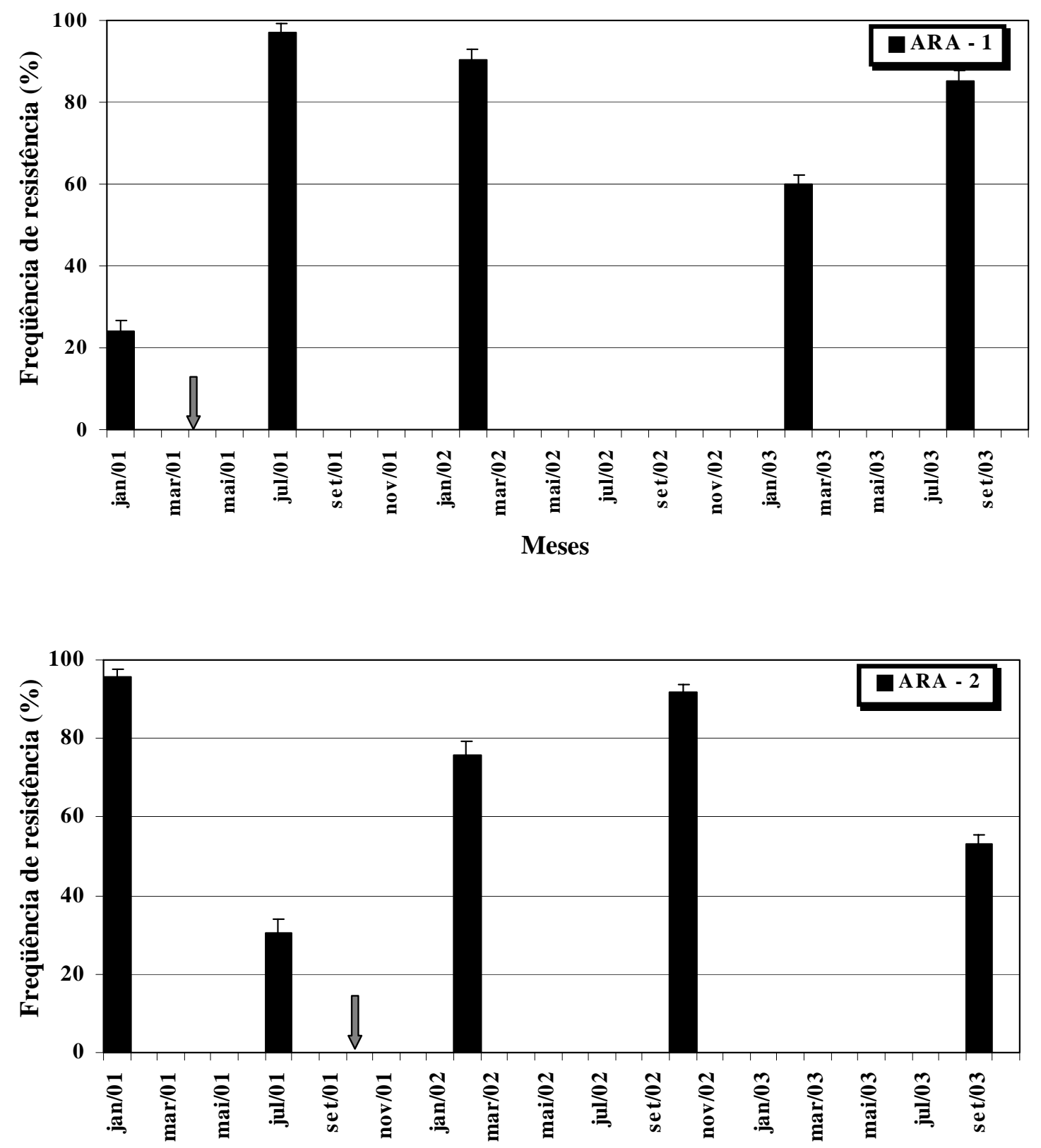

Meses

Figura 5 - Dinâmica da resistência de Brevipalpus phoenicis ao dicofol nos talhões de citros ARA-1 e ARA-2 da região de Araraquara-SP na presença de pressão de seleção. Dados de freqüência de resistência ( \pm erro padrão da média) de $B$. phoenicis estimados com bioensaio de concentração discriminatória de 32 ppm de dicofol. A seta indica a aplicação de dicofol 

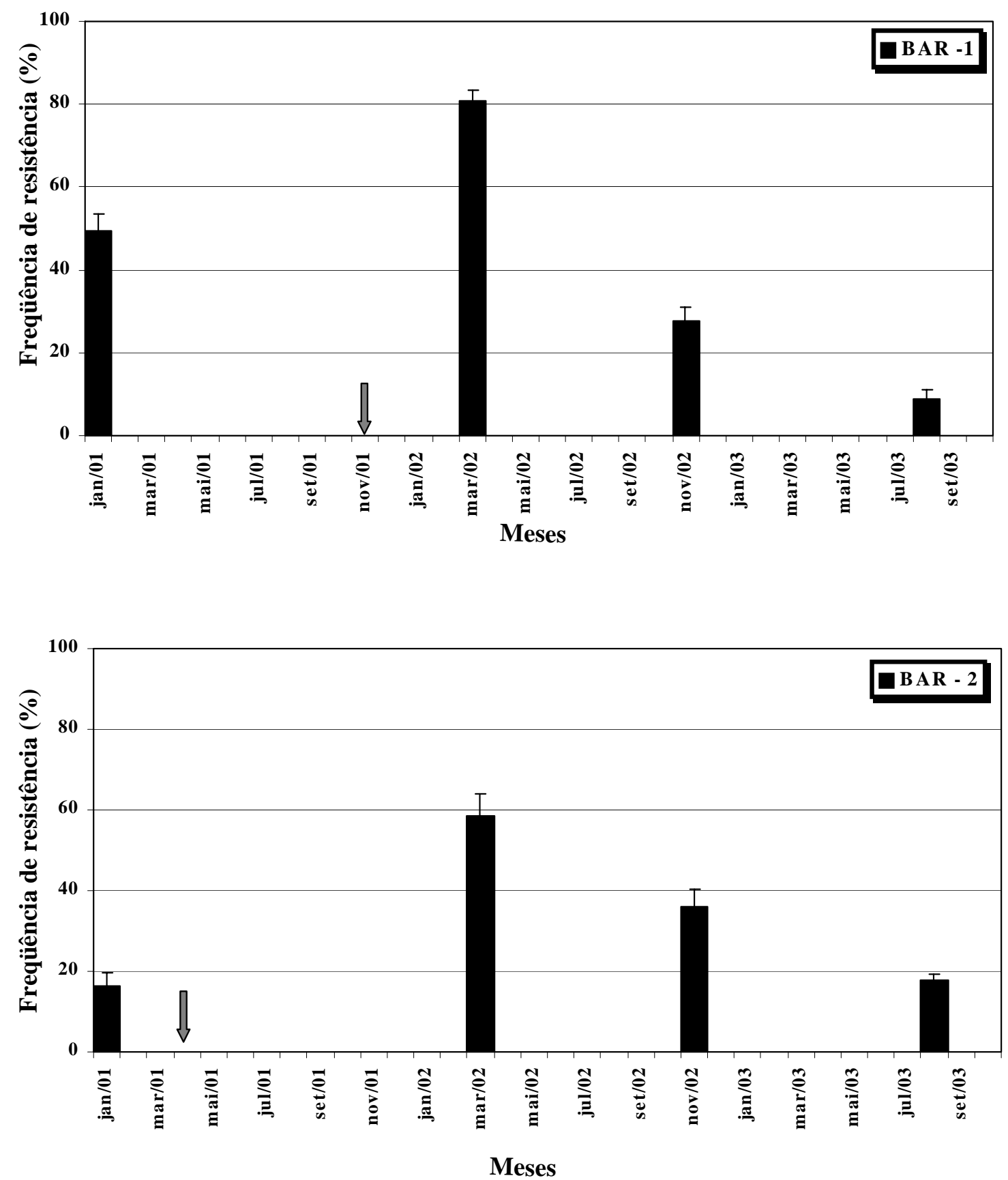

Figura 6 - Dinâmica da resistência de Brevipalpus phoenicis ao dicofol nos talhões de citros BAR-1 e BAR-2 da região de Barretos-SP na presença de pressão de seleção. Dados de freqüência de resistência ( \pm erro padrão da média) de $B$. phoenicis estimados com bioensaio de concentração discriminatória de 32 ppm de dicofol. A seta indica a aplicação de dicofol 
Talhões de citros das regiões de Araraquara e Barretos-SP que não receberam a aplicação do dicofol no ano de 2001 apresentaram decréscimos na freqüência de resistência ao longo dos anos de 2001 a 2003 (Figuras 7 e 8). No talhão ARA-3 embora a freqüência de resistência tenha decrescido significativamente (33\%; $t=4,09 ; P=$ 0,0263) entre a primeira e a última amostragem realizada 29 meses após (Figura 7), a dinâmica da resistência teve um comportamento mais estável do que os demais talhões, que apresentaram decréscimos na freqüência de resistência de 37\% para o talhão BAR-4 e 85\% para os talhões ARA-4 e BAR-3 em períodos de 14 e 21 meses. Em todos os talhões de citros avaliados, a última aplicação de dicofol realizada antes do experimento foi registrada entre 1998 a 2000 (Anexo A). Desta forma, o restabelecimento da suscetibilidade observado nos talhões de citros ARA-4, BAR-3 e BAR-4 são decorrentes da ausência de pressão seletiva com o dicofol durante os últimos 3 a 4 anos. Mesmo durante todo esse período sem uso do dicofol, o talhão ARA-3 ao final do experimento apresentou uma freqüência de resistência próxima a 60\%. 

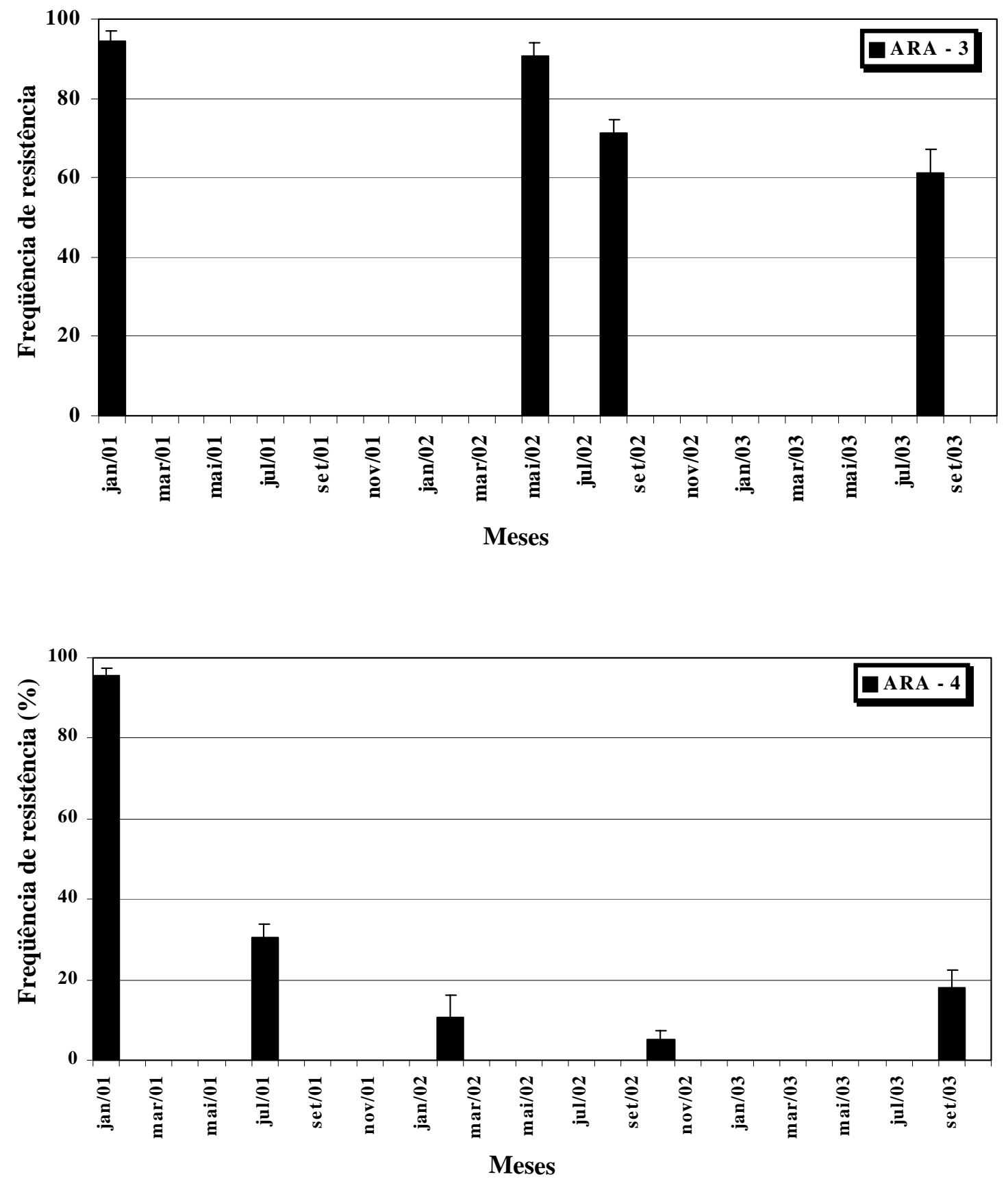

Figura 7 - Dinâmica da resistência de Brevipalpus phoenicis ao dicofol nos talhões de citros ARA-3 e ARA-4 da região de Araraquara-SP na ausência de pressão de seleção. Dados de freqüência de resistência ( \pm erro padrão da média) de $B$. phoenicis estimados com bioensaio de concentração discriminatória de 32 ppm de dicofol 


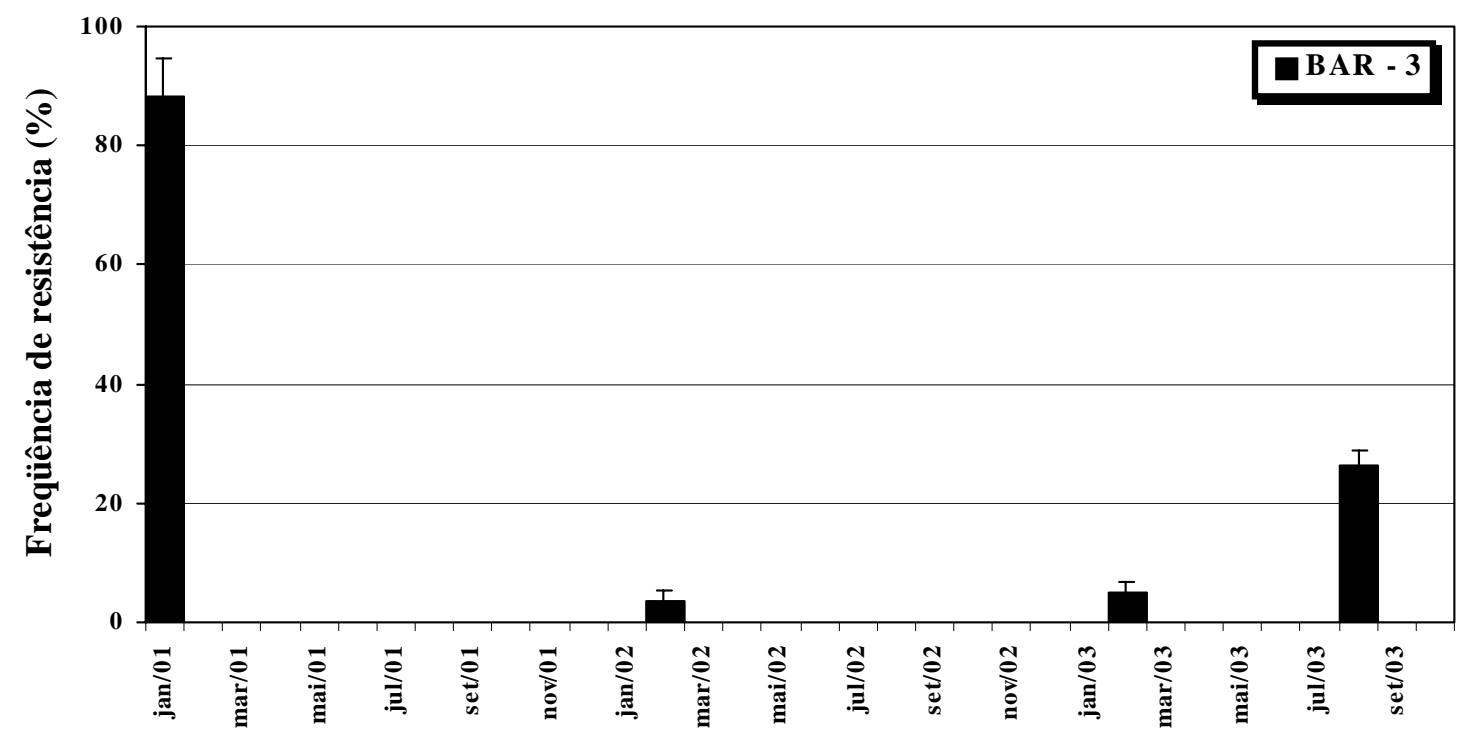

Meses

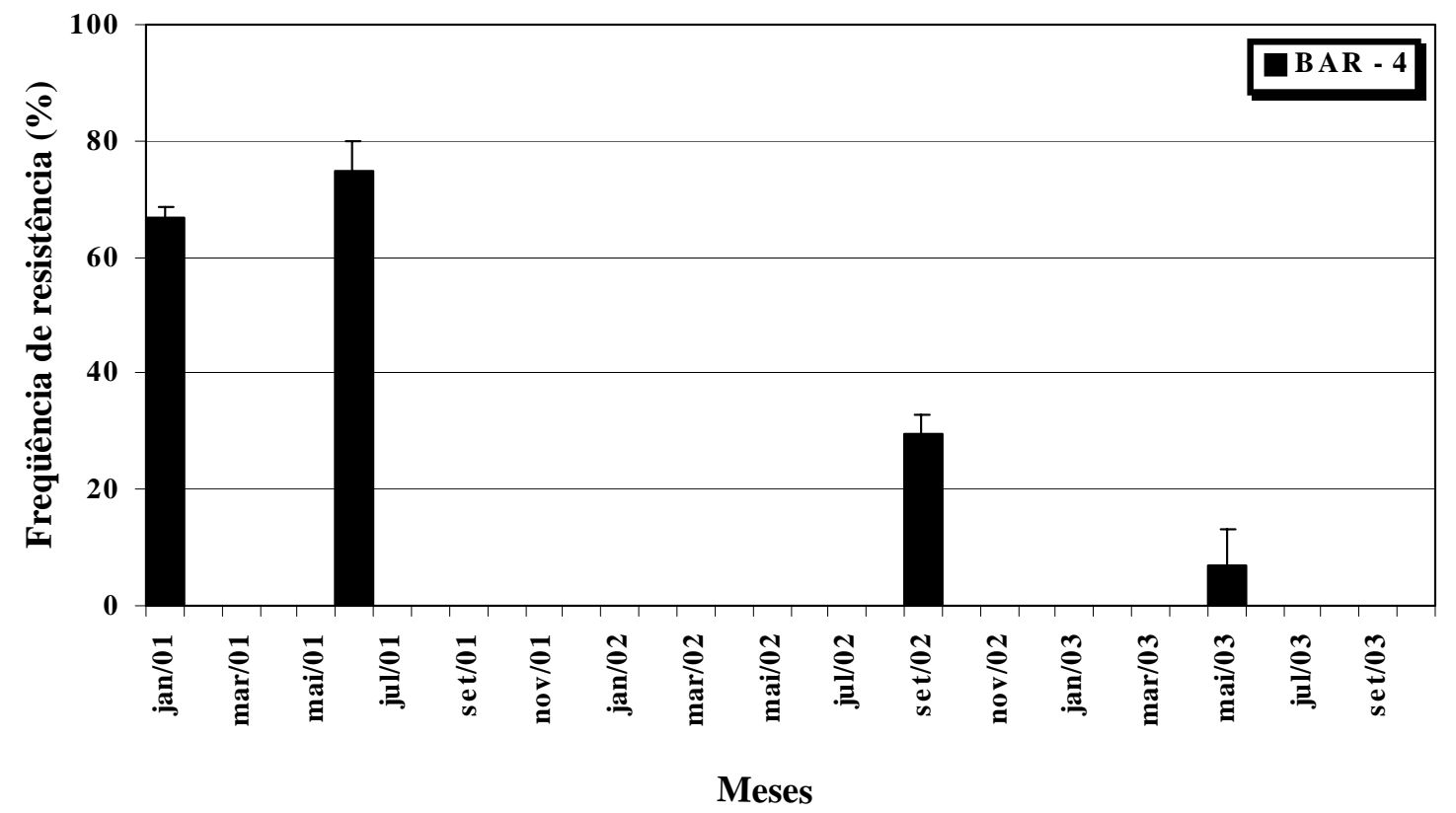

Figura 8 - Dinâmica da resistência de Brevipalpus phoenicis ao dicofol nos talhões de citros BAR-3 e BAR-4 da região de Barretos-SP na ausência de pressão de seleção. Dados de freqüência de resistência ( \pm erro padrão da média) de $B$. phoenicis estimados com bioensaio de concentração discriminatória de 32 ppm de dicofol 
A dinâmica da resistência de B. phoenicis ao dicofol apresentou um comportamento distinto entre os talhões de citros avaliados. Desta forma não foi possível estimar um intervalo mínimo de restabelecimento da suscetibilidade para este acaricida. Comparando-se o presente trabalho de dinâmica da resistência de $B$. phoenicis com trabalhos de dinâmica da resistência de outros ácaros para o dicofol, é verificado que a resistência de B. phoenicis ao dicofol é mais estável, possivelmente em função da baixa capacidade de dispersão deste ácaro de talhões de citros e de plantas hospedeiras presentes no interior e na periferia dos pomares que não receberam aplicações de acaricidas (itens 4.2, 4.3 e 4.4).

Omoto et al. (1995) estimaram um intervalo mínimo para o restabelecimento da suscetibilidade de Phyllocoptruta oleivora (Ashmead) ao dicofol de aproximadamente um ano. Trabalhos realizados por Dennehy et al. (1990) mostraram que a resistência ao dicofol é altamente instável para o ácaro Tetranychus urticae (Koch), sendo que mesmo em pomares de maçã que receberam cinco aplicações de dicofol foram tão suscetíveis quanto em pomares que não receberam aplicações de dicofol, ao contrário de Panonychus ulmi (Koch) que mostrou aumento significativo na freqüência da resistência com o aumento da pressão de seleção nos mesmos pomares.

Vários fatores poderiam ter influenciado o comportamento distinto da dinâmica da resistência ao dicofol em B. phoenicis entre os talhões, como por exemplo as diferenças no custo adaptativo associado à resistência nas populações de B. phoenicis avaliadas, a presença efetiva de refúgio próximo às áreas avaliadas e a imigração de ácaros suscetíveis das áreas de refúgio para as áreas avaliadas. Portanto, para o manejo da resistência de B. phoenicis ao dicofol, há necessidade de realização de monitoramento da suscetibilidade dos ácaros em cada talhão anteriormente à tomada de decisão de aplicação ou não do dicofol. 


\subsection{Dispersão de Brevipalpus phoenicis}

\subsubsection{Dispersão por caminhamento}

A dispersão de B. phoenicis por caminhamento foi bastante limitada. Com a liberação de 6.000 ácaros em cada distância avaliada, apenas 3\% atingiram distâncias de 40 e $50 \mathrm{~cm}$ do local de liberação após sete dias. Mesmo na distância de $10 \mathrm{~cm}$ a porcentagem de ácaros recapturados foi de apenas 30 \% (Figura 9).

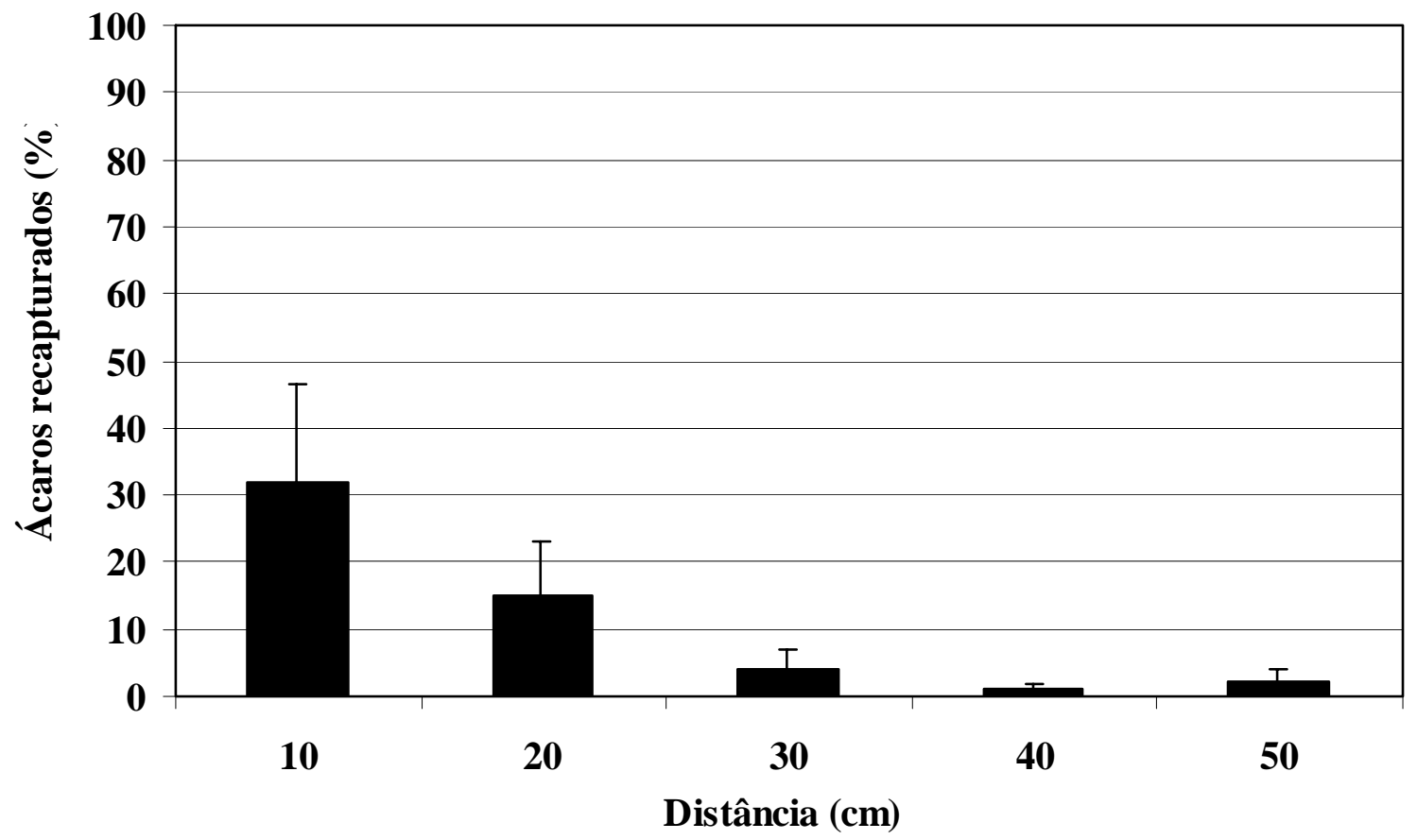

Figura 9 - Porcentagem de Brevipalpus phoenicis adultos recapturados 7 dias após liberação, nas distâncias de 10, 20, 30, 40 e 50 cm a partir do ponto de liberação

A taxa de dispersão de B. phoenicis representada pela distância (DM) e área $\left(\mathrm{S}^{2}\right)$ percorrida pelo ácaro mostraram que após a liberação dos ácaros no substrato estes se locomoveram aproximadamente $7,3 \mathrm{~cm}$ no primeiro dia e menos de $1 \mathrm{~cm} \cdot \mathrm{dia}^{-1}$ nos dias subsequentes (Tabela 2). 
Trabalhos realizados com Tetranychus urticae (Koch) mostraram a importância da dispersão por caminhamento na infestação inicial de plantações de milho, sendo que os ácaros eram provenientes de plantas hospedeiras próximas e dentro destas plantações (Brandenburg \& Kennedy, 1982; Kennedy \& Smitley, 1985). Trabalhos realizados por McGregor e Parker, citados por Kennedy \& Smitley (1985) mostraram que T. urticae pode percorrer distâncias de $5 \mathrm{~cm} \cdot \mathrm{h}^{-1}$ a $6 \mathrm{~m} \cdot \mathrm{h}^{-1}$ dependendo do tipo de solo. Com relação a ácaros predadores, tais como Phytoseiulus persimilis Athias-Henriot podem teoricamente percorrer 319 metros.dia $^{-1}$ (Bernstein, 1983). Comparando os resultados obtidos por estes autores com os resultados obtidos no presente trabalho verificamos que a capacidade de dispersão por caminhamento de $B$. phoenicis é bastante limitada e que este tipo de mecanismo de dispersão provavelmente apresenta importância direta somente na distribuição do ácaro na planta de citros e em plantas que estão em contato umas com as outras.

Maia \& Oliveira (2002) verificaram a importância de algumas plantas invasoras e cercas-vivas como hospedeiras potenciais para o desenvolvimento de populações de $B$. phoenicis e fontes de disseminação deste ácaro para os pomares de citros. Porém, caso estas plantas fossem capinadas ou roçadas, estas populações de B. phoenicis teriam pouca influência para a infestação nos citros, uma vez que os ácaros possivelmente não conseguiriam atingir as plantas de citros por caminhamento. Desta forma, o mecanismo de dispersão por caminhamento também não seria a principal estratégia para que genótipos suscetíveis tivessem uma expressão significativa na diluição da resistência de B. phoenicis a acaricidas, ao contrário das observações feitas para o ácaro T. urticae em pomares de pera em Oregon nos EUA; de acordo com Flexner et al., citados por Dunley \& Croft (1992), que reportaram que as práticas culturais através da adoção de herbicidas induziam a dispersão das populações de T. urticae presentes nas plantas invasoras dentro do pomar para as plantas de pera onde grande número de ácaros era observado se movendo nos troncos das árvores. Estes autores relataram também que a dispersão de ácaros suscetíveis das plantas hospedeiras tinha significativo impacto sobre a freqüência de resistência das populações presentes nos pomares. 
Tabela 2. Distância (DM) e área $\left(\mathrm{S}^{2}\right)$ percorrida por Brevipalpus phoenicis no decorrer de quatro dias de avaliação, calculadas a partir de fórmulas propostas por Dobzansky \& Wright, citados por Silveira Neto et al. (1976)

\begin{tabular}{|c|c|c|}
\hline $\begin{array}{c}\text { Dias após liberação } \\
\text { dos ácaros }\end{array}$ & $\begin{array}{c}\text { Distância Percorrida (DM) } \\
\text { (cm) }\end{array}$ & $\begin{array}{c}\text { Área percorrida }\left(\mathrm{S}^{2}\right) \\
\left(\mathrm{cm}^{2}\right)\end{array}$ \\
\hline 1 & 7,33 & 156,84 \\
\hline 2 & 0,91 & 236,52 \\
\hline 3 & 0,87 & 211,94 \\
\hline 4 & 0,90 & 462,04 \\
\hline
\end{tabular}

\subsubsection{Dispersão pelo vento}

\section{Estudos de laboratório}

A interação de velocidades de vento de 23, 30 e $40 \mathrm{~km} \cdot \mathrm{h}^{-1}$ testadas e o tempo de exposição das colônias de B. phoenicis de 30 e 60 minutos foi significativa $(F=3,93$; g.l.=2, 15; $P<0,05)$. A porcentagem de ácaros capturados nas velocidades testadas foi diferente para os tempos de 30 e 60 minutos em que as colônias de $B$. phoenicis permaneceram expostas às correntes de vento $(F=43,78$; $\mathrm{gl}=2,15 ; P<0,05)$. Porém, a porcentagem de ácaros coletados para os tempos de 30 e 60 minutos dentro das velocidades estudadas não diferiu significativamente $(F=0,55 ; \mathrm{gl}=1,25 ; P>0,05)$. A velocidade de $30 \mathrm{~km} \cdot \mathrm{h}^{-1}$ proporcionou uma maior porcentagem de ácaros capturados em relação à velocidade de $40 \mathrm{~km} \cdot \mathrm{h}^{-1}$ nos 30 minutos iniciais de exposição das colônias de B. phoenicis as correntes de vento. Colônias de B. phoenicis expostas por 60 minutos às correntes de vento de 30 e $40 \mathrm{~km} \cdot \mathrm{h}^{-1}$ não diferiram significativamente com relação à porcentagem de ácaros capturados. A velocidade de $23 \mathrm{~km} . \mathrm{h}^{-1}$ não foi capaz de arrastar B. phoenicis da superfície dos frutos (Tabela 3). As velocidades de 23 e $30 \mathrm{~km} . \mathrm{h}^{-1}$ foram próximas às velocidades médias encontradas em condições de campo. A velocidade de 
$40 \mathrm{~km} \cdot \mathrm{h}^{-1}$ pode ser considerada como uma velocidade máxima média encontrada em condições de campo.

Colônias novas de B. phoenicis recentemente estabelecidas em frutos e colônias velhas apresentando sinais de fuga de ácaros da arena de criação no fruto submetidas à velocidade de $30 \mathrm{~km} . \mathrm{h}^{-1}$ diferiram estatisticamente na porcentagem de ácaros capturados na armadilha $(F=33,28$; g.l. $=1,13 ; P<0,05)$. Ácaros presentes em frutos velhos não apresentaram um maior comportamento de fuga na presença de correntes de vento com a velocidade de $30 \mathrm{~km} \cdot \mathrm{h}^{-1}$ (Tabela 4). Estudos de dispersão aérea com o ácaro Panonychus ulmi (Koch) em pomares de maçã em Nova York também mostraram que este ácaro se dispersa quando a população não se encontra em condições de estresse ocasionado por altas densidades populacionais e escassez alimentar (Lawson et al., 1996).

A dispersão aérea de $B$. phoenicis submetidas a correntes de vento em condições laboratoriais mostrou ser limitada. Por outro lado, um experimento semelhante ao realizado no presente estudo conduzido por Slykhuis (1955), verificou-se através de um ventilador que o vento era um mecanismo de dispersão do ácaro Aceria tulipae Keifer responsável por infestações significativas de plantações de trigo por este ácaro.

Tabela 3. Porcentagem de Brevipalpus phoenicis arrastados da superfície de frutos por diferentes velocidades de vento após 30 e 60 minutos de exposição a correntes de vento

\begin{tabular}{ccccc}
\hline $\begin{array}{c}\text { Velocidade } \\
\left(\mathbf{k m} \cdot \mathbf{h}^{\mathbf{- 1}} \mathbf{)}\right.\end{array}$ & \multicolumn{3}{c}{ Média (\%) de ácaros capturados $\pm \mathbf{E P}$} \\
& $\mathbf{3 0}$ minutos & $\mathbf{6 0}$ minutos & \\
\hline 23 & 0,00 & $\mathrm{~A} \mathrm{a}^{1}$ & 0,00 & $\mathrm{~A} \mathrm{a}^{1}$ \\
30 & $0,81 \pm 0,14$ & $\mathrm{~A} \mathrm{~b}$ & $1,16 \pm 0,45$ & $\mathrm{~A} \mathrm{~b}$ \\
40 & $0,25 \pm 0,14$ & $\mathrm{~A} \mathrm{a}$ & $0,83 \pm 0,57$ & $\mathrm{~A} \mathrm{~b}$ \\
\hline${ }^{1}$ letras maiúsculas iguais na mesma linha não diferem significativamente ao nível de \\
5\%. Letras minúsculas iguais na coluna não diferem significativamente ao nível de 5\%
\end{tabular}


Tabela 4. Influência da idade de colônias de Brevipalpus phoenicis na porcentagem de ácaros arrastados por vento com velocidade de $30 \mathrm{~km} . \mathrm{h}^{-1}$ em 30 e 60 minutos de exposição

Idade das Colônias

\begin{tabular}{ccclc}
\hline Novas & $0,81 \pm 0,14$ & $\mathrm{Aa}^{1}$ & $1,16 \pm 0,45$ & $\mathrm{Aa}^{1}$ \\
Velhas & $0,07 \pm 0,03$ & $\mathrm{Ab}$ & 0,00 & $\mathrm{Ab}$ \\
\hline
\end{tabular}

${ }^{1}$ letras maiúsculas iguais na mesma linha não diferem significativamente ao nível de 5\%. Letras minúsculas iguais na coluna não diferem significativamente ao nível de 5\%

\section{Estudo de campo}

Durante a condução do experimento, um total de 11 e 78 adultos de B. phoenicis foram coletados nas armadilhas posicionadas no interior dos pomares, respectivamente nos talhões A e B do pomar de citros localizado em Descalvado-SP (Figuras 10 A e 10 B). Foram coletados apenas três adultos B. phoenicis na periferia do talhão B de Descalvado-SP e na periferia do pomar da Escola Superior de Agricultura "Luiz de Queiroz" em Piracicaba-SP, no período de junho a dezembro de 2002.

Um total 2.420 e 661 ácaros das famílias Tetranychidae, Tenuipalpidae e Phytoseiidae foram registrados, respectivamente para os talhões A e B. Aproximadamente 99\% e 83\% dos totais de ácaros coletados pertenciam à família Tetranychidae, 0,8 e 4,8\% à família Phytoseiidae e 0,45 e 11,8\% à família Tenuipalpidae, respectivamente nos talhões A e B (Figuras 11 A e 11 B).

A avaliação da dispersão de $B$. phoenicis pelo vento mostrou que este ácaro apresenta uma dispersão bastante limitada em condições de campo, como foi sugerido pelo experimento em laboratório onde ventos de até $40 \mathrm{~km} \cdot \mathrm{h}^{-1}$ não foram suficientes para arrastar grandes quantidades de B. phoenicis presentes na superfície de frutos de citros. A reduzida capacidade do vento em dispersar B. phoenicis pode ser explicada pela anatomia plana deste ácaro e pelo comportamento de se esconder em frestas ou 
saliências e nas lesões de verrugose nos frutos e ramos (Chiavegato, 1986; Nakano et al., 1987), além de não apresentarem um comportamento de dispersão diante de estímulos como a presença de correntes de vento ou mesmo estresse provocado pela falta de alimento, como foi registrado para ácaros da família Tetranychidae (Gerson, 1985; Kennedy \& Smitley, 1985) e Eriophyidae (Nault \& Styer, 1969; Bergh \& McCoy, 1997) onde os ácaros formam aglomerados no topo das plantas para serem levados pelo vento ou mesmo apresentam comportamentos de produzirem teias ou se inclinarem para tomar as correntes de vento. O reduzido número de ácaros tenuipalpídeos coletados em campo pelas armadilhas adesivas também pode estar associado à baixa densidade populacional deste ácaro que é tolerada nos pomares de citros que é de até 10\% de infestação (Salva, 1994). Este fato pode ser observado nas amostragens realizadas nos talhões A e B (Figuras 10 A e $10 \mathrm{~B}$ ).

Coletas de $P$. oleivora utilizando armadilhas adesivas confeccionadas com laminas plásticas de $12,5 \mathrm{~cm}^{2}$ resultaram na coleta de 280 a 1.379 ácaros em pomares de citros na Flórida nos meses de maio a agosto de 1995, mostrando a alta capacidade de dispersão deste eriofídeo pelo vento (Bergh \& McCoy, 1997). Estudos de dispersão através do uso de armadilhas adesivas com dimensões de 18 x $18 \mathrm{~cm}$ foram eficientes para mostrar que a freqüência de resistência entre populações de ácaros tetraniquídeos coletados em culturas de algodão e amêndoa apresentavam freqüência similar devido à grande capacidade de dispersão deste ácaro de uma cultura para outra na Califórnia (Grafton-Cardwell et al., 1991).

Os resultados apresentados neste trabalho indicam que a dispersão pelo vento não teria influência significativa na reversão da resistência de B. phoenicis, como observado para ácaros da família Eriophyidae em citros, na Flórida (Bergh \& McCoy, 1997; Bergh, 2001) e Tetranychidae em algodão, na Califórnia (Grafeton-Cardwell et al., 1991). Porém, o reduzido número de ácaros que se dispersam seriam suficientes para formar focos significativos de infestação de B. phoenicis nos pomares a longo prazo, como relata trabalhos de bioecologia e de simulação realizados por Kennedy et al. (1996) para a cultura do chá, onde foi demonstrado que com um número inicial de 10 ácaros, uma 
população de $1,5 \times 10^{10}$ indivíduos seria obtida após 156 dias quando os parâmetros demográficos se tornariam constantes.

No presente trabalho foi verificado um maior número de B. phoenicis sendo deslocados pelo vento no sentido da linha de citros do que entre as linhas. Dos 89 ácaros coletados nos talhões A e B, 51 ácaros foram coletados dispersando-se no sentido da linha de citros e 38 ácaros foram coletados dispersando-se entre as linhas de citros, porém a diferença de ácaros coletados entre os dois sentidos não foi significativa ( $F=$ 1,83; $g l=1,10 ; P>0,05$ ), possivelmente pelo baixo número de $B$. phoenicis coletados durante o período de amostragem. Também não foi encontrada diferença significativa entre as armadilhas colocadas em diferentes alturas $(F=0,02 ; g l=2,6 ; P>0,05)$. As armadilhas posicionadas à $1,5 \mathrm{~m}$ da periferia do pomar diferiram estatisticamente das armadilhas posicionadas à 15 e $45 \mathrm{~m}(F=8,63 ; g l=2,6 ; P<0,05)$. Nas armadilhas posicionadas à 1,5 $\mathrm{m}$ da periferia do pomar foram coletados 54 ácaros enquanto que as armadilhas posicionadas à 15 e $45 \mathrm{~m}$ foram responsáveis pela coletas de 35 ácaros. Rodrigues (2002) estudando a dinâmica da doença leprose em um pomar também verificou que o desenvolvimento da doença é maior no sentido da linha do que entre as linhas de citros, sugerindo que a dispersão do ácaro B. phoenicis é maior no sentido da linha devido às distâncias entre as plantas serem menores do que entre as linhas, ampliando-se, assim a probabilidade dos ácaros atingirem essas plantas em maior quantidade. Porém, o maior número de ácaros coletados no sentido da linha possivelmente está relacionado com a maior facilidade com que as correntes de vento conseguem percorrer o pomar neste sentido. 


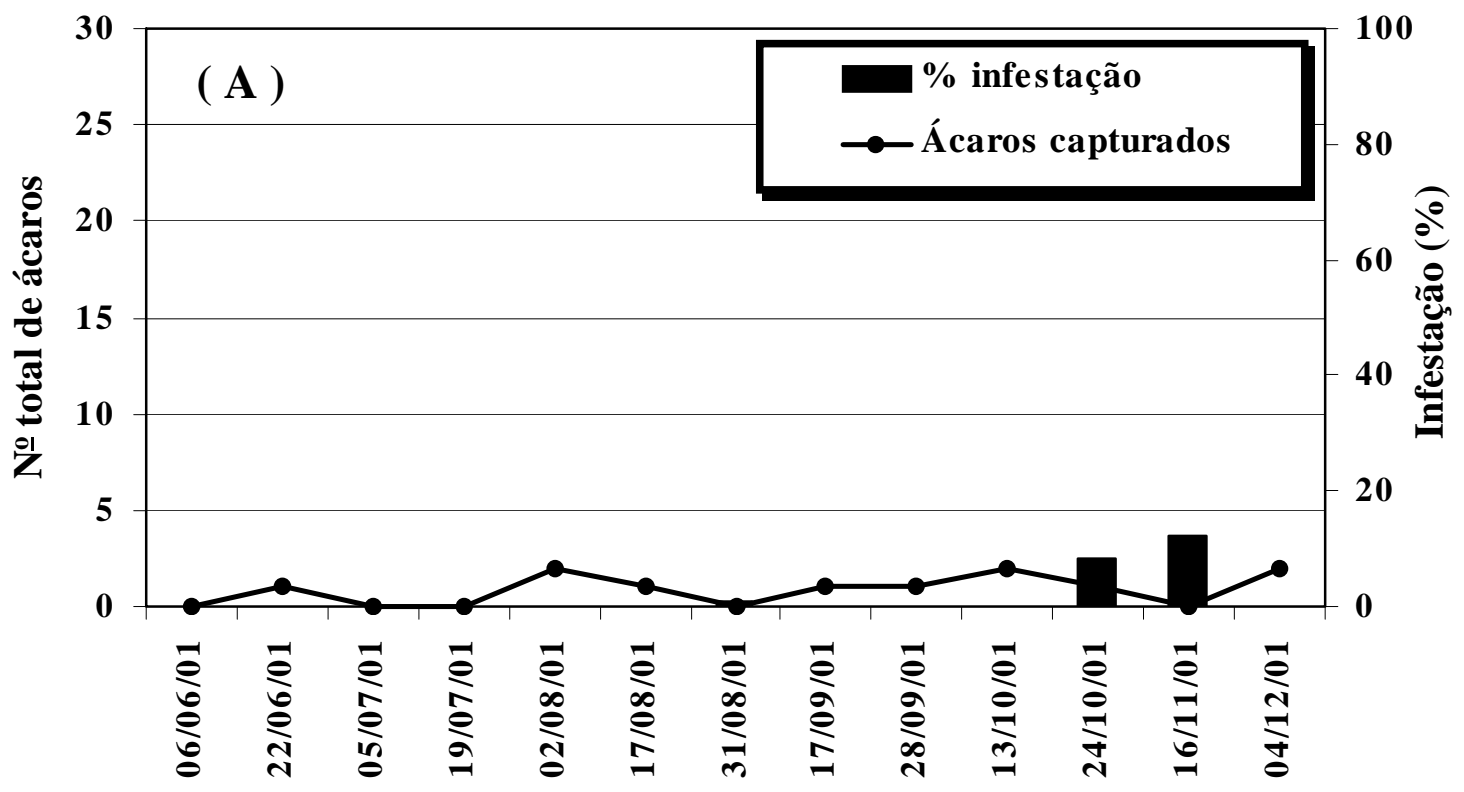

Período de coleta

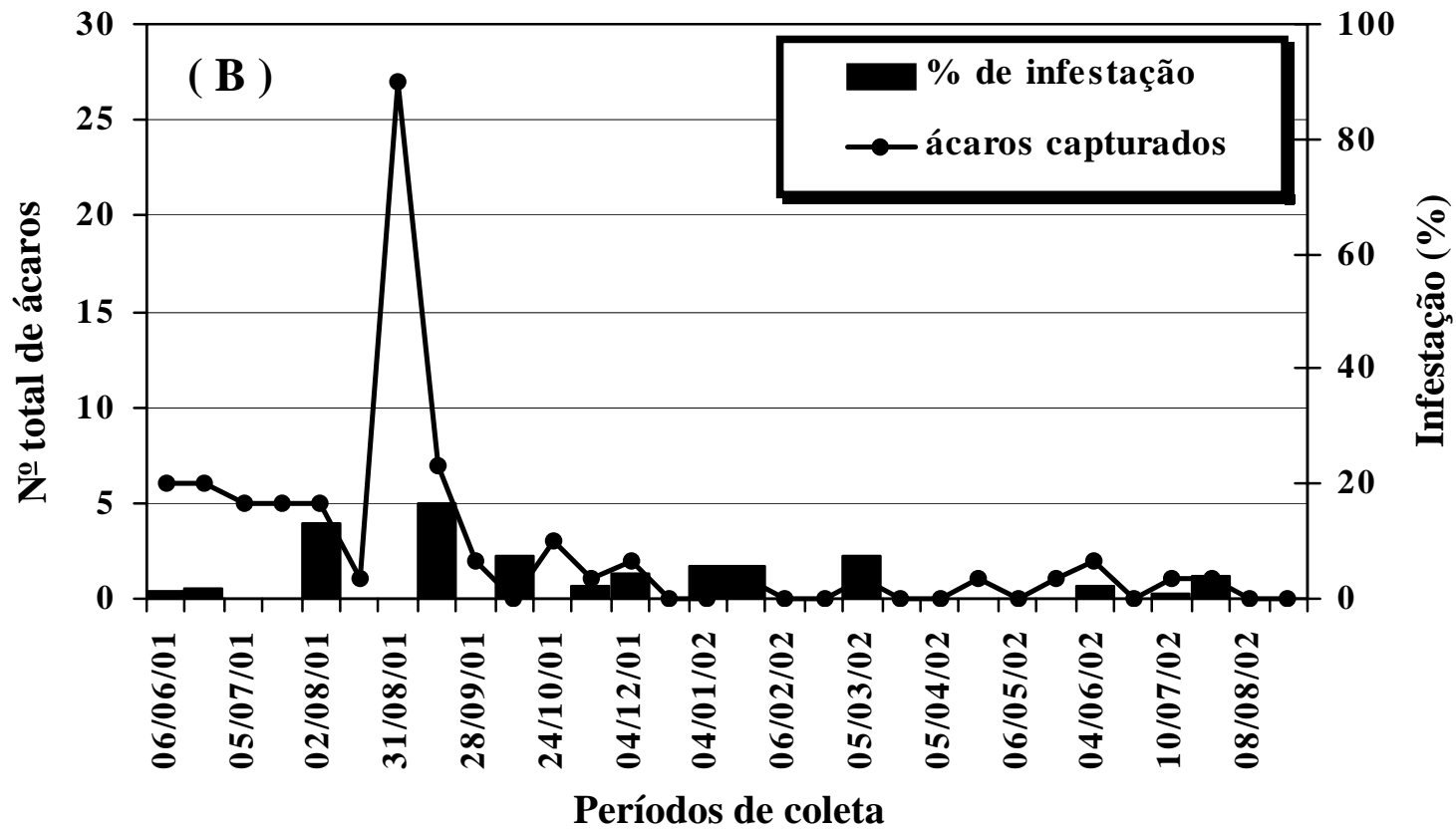

Figura 10 - Número total de adultos de Brevipalpus phoenicis coletados e porcentagem de infestação de $B$. phoenicis em diferentes épocas em dois talhões de citros (A e B) localizados em um pomar da região de Descalvado-SP 


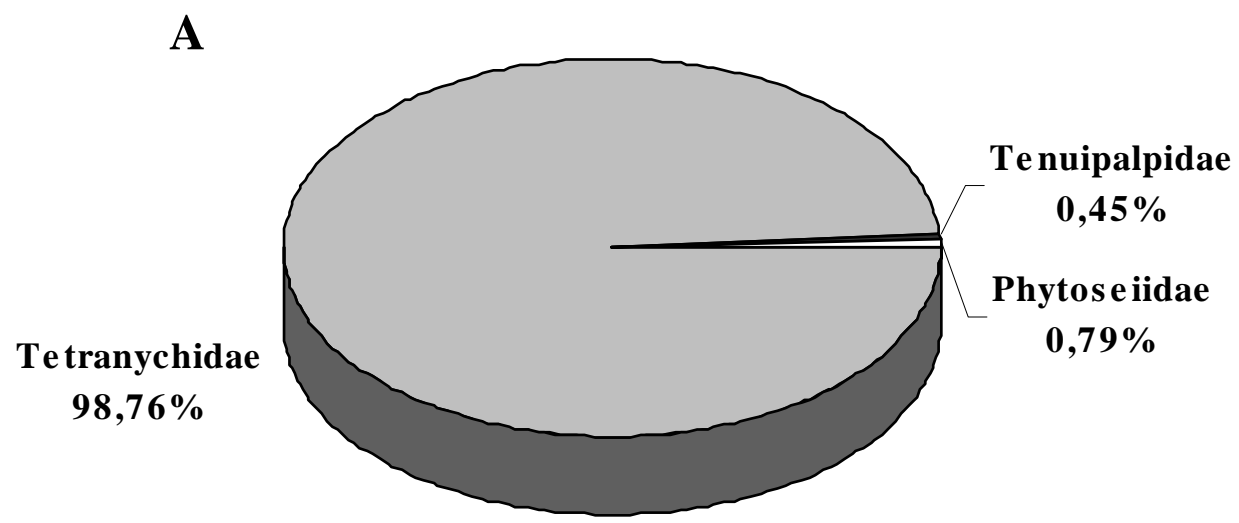

$\mathbf{n}=\mathbf{2 4 2 0}$

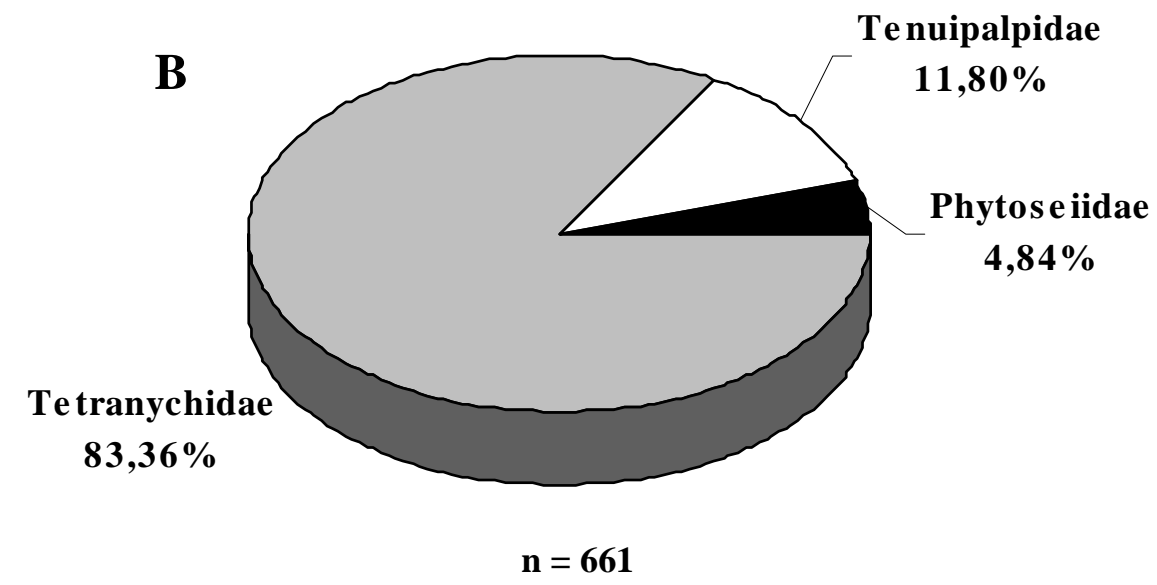

Figura 11 - Porcentagem relativa de ácaros das famílias Tetranychidae, Tenuipalpidae e Phytoseiidae coletados em armadilhas adesivas instaladas em dois talhões de citros (A e B) de um pomar localizado na região de Descalvado-SP. (n=número total de ácaros coletados durante o experimento) 


\subsection{Freqüência de resistência ao dicofol em populações de Brevipalpus phoenicis coletadas em citros e sansão-do-campo}

As freqüências de resistência ao dicofol em populações de B. phoenicis coletadas em sansão-do-campo (Mimosa caesalpiniaefolia Benth.) foram significativamente inferiores à freqüência de resistência de suas respectivas populações de $B$. phoenicis coletadas em citros (Citrus sinensis L.) para a maioria dos pomares amostrados, com exceção do pomar da ESALQ em Piracicaba e um dos talhões do pomar de citros localizado em Bauru-SP (Tabela 4). As freqüências de resistência das populações de $B$. phoenicis coletadas em citros e sansão-do-campo na ESALQ não diferiram estatisticamente devido às freqüências de resistência terem sido inferiores a $1 \%$ mostrando a baixa pressão de seleção com o dicofol neste pomar. O pomar da ESALQ tem em seu histórico de uso de acaricidas, um número médio inferior a uma aplicação de acaricida por ano, sendo que não havia registros de aplicação do dicofol nos últimos sete anos. Além deste fato, a densidade populacional do ácaro-da-leprose é mantida alta (superior a 20\%) e poucos tratos culturais (p. ex. o controle de plantas invasoras) são realizados; condições estas que favorecem a preservação da suscetibilidade de $B$. phoenicis a acaricidas. Já no talhão VEN-1 em Bauru-SP, a freqüência de resistência ao acaricida dicofol para a população de $B$. phoenicis em sansão-do-campo foi significativamente maior (44 \%) do que a freqüência de resistência da população de citros. Aplicações de dicofol não foram registradas nos últimos 3 anos neste talhão, assim como na cerca-viva de sansão-do-campo. A população de B. phoenicis do sansãodo-campo no talhão VEN-1 também não pode ter sido selecionada para resistência pela deriva do dicofol aplicado em talhões vizinhos, pois a cerca-viva estava isolada dos demais talhões.

A estimativa da freqüência de resistência das populações de $B$. phoenicis coletadas em sansão-do-campo apresentou uma variação na freqüência de resistência de 0 a 70\% entre os locais de amostragem (Tabela 5). Talhões com alta freqüência de resistência ao acaricida dicofol (superior a 95\%) mostraram estimativas variáveis da freqüência de resistência para as populações de $B$. phoenicis coletadas nas respectivas 
cercas-vivas. Por exemplo, as populações do ácaro-da-leprose coletadas em sansão-docampo nos talhões ER-2 e ER-3 apresentaram freqüências de resistência próximas a 40\%. Já para o talhão MAR-1, a freqüência de resistência da população do sansão-docampo vizinho foi de apenas 5\%.

O sansão-do-campo, embora seja um bom hospedeiro de B. phoenicis e um foco de disseminação do ácaro-da-leprose para os pomares de citros como sugerido por trabalhos de Maia \& Oliveira (2002), não é um alvo direto da aplicação de acaricidas para o controle deste ácaro. A pressão de seleção nas populações de $B$. phoenicis presentes em sansão-do-campo é resultante da deriva dos produtos aplicados nos pomares ao lado deste hospedeiro, desta forma, o sansão-do-campo constitui uma fonte de indivíduos suscetíveis para os citros em muitos dos pomares que foram amostrados no trabalho. Porém, a baixa freqüência de resistência nas populações de $B$. phoenicis presentes em sansão-do-campo associado à capacidade limitada de dispersão deste ácaro também sugerem que estas fontes de ácaros suscetíveis não teriam muita importância para a reversão da resistência, pelo menos a curto prazo. Plantas presentes na periferia e/ou no interior do pomar que não recebem aplicações de acaricidas desempenham papel fundamental na dinâmica da resistência de ácaros a acaricidas em muitas culturas, como por exemplo na cultura de pera no Oregon, EUA onde foi observado que pomares que possuíam ao seu redor vegetação nativa que abrigavam populações suscetíveis de $T$. urticae apresentavam reversão mais rápida da resistência aos acaricidas organoestânicos do que pomares que não possuíam plantas nativas ao seu redor (Dunley \& Croft, 1992).

Se a dispersão de $B$. phoenicis fosse intensa, as populações amostradas em sansão-do-campo deveriam na maioria dos casos ter uma freqüência de resistência ao dicofol bastante próxima à freqüência de resistência das populações coletadas em citros, pois os dois hospedeiros estavam a apenas 10 metros de distância. Trabalhos de Grafton-Cardwell et al. (1991), relatam que a freqüência de resistência ao dicofol de populações de ácaros tetraniquídeos atacando culturas vizinhas de algodão e amêndoa nos Estados Unidos são aproximadamente iguais, mesmo a cultura da amêndoa não recebendo pulverizações com o dicofol, devido à grande capacidade de dispersão deste ácaro entre as duas culturas. Miller et al. (1985) verificaram que plantações novas de 
framboesa na Califórnia nos Estados Unidos inicialmente eram infestadas por T. urticae presentes em hospedeiros do campo, porém em menos de dois anos, T. urticae resistentes provenientes de plantações mais antigas de framboesa vizinhas imigravam para a nova plantação, aumentando assim a freqüência de resistência para acaricidas como cihexatin e formetanato devido ao intenso fluxo gênico. Por outro lado, a ausência de comportamento de dispersão também foi observada para o ácaro predador Typhlodromus pyri Scheuten cujas populações encontradas a 10 metros do pomar apresentavam uma freqüência de resistência a acaricidas organofosforados bastante inferior àquela encontrada nas populações de dentro do pomar. Estudos realizados nestes pomares com populações de Metaseiulus occidentalis (Nesbitt) verificaram que ao contrário de T. pyri, a dispersão deste ácaro era bastante intensa entre a cultura e as plantas da periferia, uma vez que a freqüência de resistência das populações era similar (Dunley \& Croft, 1992).

Se o isolamento das populações do ácaro-da-leprose nos citros favorecesse um aumento mais rápido da freqüência de resistência bem como uma maior estabilidade da resistência (Georghiou \& Taylor, 1977a; Dennehy et al., 1990), por outro lado este isolamento permitiria que as estratégias de manejo da resistência nesta cultura sejam implementadas no âmbito da propriedade ou mesmo de talhão de citros como sugere os resultados obtidos por Omoto et al. (2000) que encontraram uma grande variabilidade na freqüência de resistência entre talhões de um mesmo pomar. 
Tabela 5. Freqüência de resistência ( \pm erro padrão da média) ao acaricida dicofol de populações de Brevipalpus phoenicis coletadas em citros e sansão-do-campo

\begin{tabular}{|c|c|c|c|c|}
\hline \multirow{2}{*}{ População } & \multicolumn{2}{|c|}{ Hospedeiros } & \multirow{2}{*}{$t^{*}$} & \multirow{2}{*}{ Probabilidade } \\
\hline & Citros & Sansão-do-campo & & \\
\hline ESALQ & $0,00 \pm 0,00$ & $0,85 \pm 0,85$ & $-1,00$ & 0,4226 \\
\hline ER-1 & $27,43 \pm 4,21$ & $2,95 \pm 1,20$ & 6,93 & 0,0202 \\
\hline ER-2 & $95,48 \pm 1,87$ & $40,14 \pm 3,33$ & 10,34 & 0,0001 \\
\hline ER-3 & $97,54 \pm 1,34$ & $43,62 \pm 2,72$ & 14,04 & 0,0001 \\
\hline MAR-1 & $97,50 \pm 1,44$ & $5,43 \pm 2,53$ & 17,55 & 0,0032 \\
\hline MAR-2 & $86,50 \pm 3,22$ & $24,81 \pm 2,99$ & 8,83 & 0,0009 \\
\hline BG-1 & $66,12 \pm 2,61$ & $46,86 \pm 4,55$ & 2,93 & 0,0428 \\
\hline BG-2 & $13,65 \pm 3,42$ & $3,50 \pm 2,45$ & 4,77 & 0,0088 \\
\hline BG-3 & $43,85 \pm 1,84$ & $26,99 \pm 3,40$ & 5,17 & 0,0066 \\
\hline SJ-1 & $61,20 \pm 5,16$ & $18,26 \pm 4,25$ & 6,53 & 0,0028 \\
\hline SJ-2 & $63,71 \pm 2,82$ & $3,90 \pm 1,64$ & 15,21 & 0,0001 \\
\hline VEN-1 & $23,97 \pm 4,45$ & $68,28 \pm 6,05$ & $-6,74$ & 0,0025 \\
\hline VEN-2 & $34,68 \pm 4,34$ & $0,00 \pm 0,00$ & 7,74 & 0,0015 \\
\hline
\end{tabular}

*Valores de $t$ estimados através de teste $t$ unilateral entre as populações da mesma linha.

\subsection{Análise da variabilidade genética através da técnica RAPD - PCR em populações de Brevipalpus phoenicis coletadas em citros e sansão-do-campo}

A técnica de DNA polimórfico amplificado ao acaso (RAPD - PCR) foi eficiente para verificar diferenças entre populações de B. phoenicis coletadas em citros ( $C$. sinesis) e sansão-do-campo (M. caesapiniaefolia) dentro do pomar e entre as regiões avaliadas (Figura 12). Os dez iniciadores utilizados para encontrar diferenças genéticas produziram 61 bandas polimórficas. A análise multilocus de diversidade gênica realizada através do programa POPGENE, software versão 1.32 estimou que as 
populações de B. phoneicis coletadas em sansão-do-campo apresentaram maior diversidade gênica $(\mathrm{H})$ e maior número e proporção de loci polimórficos do que as populações de B. phoenicis coletadas em citros (Tabela 6; Figura 13). A análise de diversidade gênica $(\mathrm{H})$ de populações de $B$. phoenicis coletadas em citros e sansão-docampo nas diferentes regiões avaliadas do Estado de São Paulo indicaram que a maior diversidade gênica e número de loci polimórficos ocorreu entre as populações de citros e sansão-do-campo da região de Onda Verde que apresentaram um H de 0,2808 e 56,16\% de loci polimórficos, porém o desvio padrão do $\mathrm{H}$ foi alto para todas as regiões avaliadas (Tabela 7).

A análise multi-populacional da diversidade gênica entre as 12 populações de $B$. phoenicis coletadas nos hospedeiros citros e sansão-do-campo em 6 localidades do Estado de São Paulo estimou que a diversidade gênica intrapopulação (Hs) foi muito maior entre os hospedeiros de B. phoenicis avaliados do que entre as regiões de coleta das populações de B. phoenicis e o coeficiente de diferenciação gênica (Gst) foi maior entre as regiões do que entre os hospedeiros, indicando menor variação genética das populações de $B$. phoenicis entre os locais e maior variação genética entre os hospedeiros (Tabela 8; Figura 13).

As distâncias genéticas das populações coletadas em sansão-do-campo foram maiores do que as distâncias genéticas das populações coletadas em citros, enquanto que a identidade genética foi menor para as populações coletadas em sansão-do-campo do que para as populações coletadas em citros (Tabela 9). A estimativa da identidade genética e distância genética das 12 populações de $B$. phoenicis avaliadas estão de acordo com os resultados apresentados para a diversidade gênica.

A análise molecular da variância (AMOVA) rejeitou a hipótese de nulidade ao nível de 99\% de probabilidade $(P<0,001)$ indicando diferenças estatísticas significativas entre as populações de B. phoenicis coletadas em citros e sansão-do-campo, sendo que 89\% da variação entre estas populações foi explicada por diferenças das populações dentro de cada hospedeiro e apenas 11\% entre as populações dos diferentes hospedeiros. Já a hipótese de nulidade não foi rejeitada entre as populações coletadas nas diferentes localidades $(P=0,199)$. Além disso, $100,3 \%$ da variância observada foi devido a 
diferenças encontrada dentro de cada local (o que corresponde à diferenças observadas entre os dois hospedeiros distintos). Portanto, esses dados corroboram com os dados discutidos anteriormente de que as variações entre populações de B. phoenicis encontradas nesse estudo ocorreram principalmente entre populações de hospedeiros distintos e não entre locais diferentes (Figura 13).

Trabalhos realizados por Navajas (1998) com populações de T. urticae provenientes de diferentes regiões mostraram que este ácaro apresenta certa diferenciação hospedeira mesmo sendo uma espécie polífaga e altamente móvel, sendo que esta diferenciação também poderia estar ligada à plasticidade da espécie. Porém, neste mesmo estudo as populações foram coletadas em regiões distintas. No presente trabalho, as populações de B. phoenicis coletadas em citros e sansão-do-campo de cada região vieram de um mesmo local, sendo as coletas realizadas a poucos metros de distância uma da outra. Desta forma, o fluxo gênico entre as populações dos dois hospedeiros deveria ser intenso de forma que elas não apresentassem diferenciação genética resultante de isolamento no espaço. Porém, a falta de mecanismos eficientes de dispersão de B. phoenicis apresentada neste trabalho no item 4.2 pode ser um fator de isolamento no espaço e consequentemente explicar as diferenças entre as populações dos dois hospedeiros dentro de um mesmo pomar. O reduzido número de $B$. phoenicis que chegariam em cada hospedeiro seria incapaz de favorecer um fluxo gênico eficiente entre as populações vizinhas.

Outro fator importante que deve ser considerado para explicar as diferenças das populações de $B$. phoenicis entre hospedeiros é o modo de reprodução do tipo partenogênese telítoca associado ao efeito do fundador (Helle et al., 1980; Pijnacker et al.,1980). A reprodução partenogenética telítoca favoreceria a ausência de variação genética dentro da população, desta forma os poucos indivíduos que chegassem ao hospedeiro seriam suficientes para dominar rapidamente este nicho e impor as características genéticas para a população atual (Puterka et al., 1993).

A falta de relação entre a distância geográfica e a distância genética das populações de citros e a menor distância genética entre as populações de B. phoenicis provenientes de citros comparada às de sansão-do-campo podem estar ligadas ao sistema 
de produção de mudas de citros que geralmente é realizado nas regiões de Araraquara e Bebedouro que apresenta condições mais adequadas para o desenvolvimento da planta. Posteriormente as mudas são distribuídas para as diversas regiões citrícolas do Estado de São Paulo. Puterka et al. (1993) relataram que a análise genética através de RAPD em populações do afídeo Diuraphis noxia (Mordvilko) nos EUA também apresentou baixa relação entre a distância geográfica e a distância genética devido às populações deste afídeo estarem distribuídas pelo país em função do comércio das plantas. Porém, trabalhos de variabilidade genética com outros artrópodes com modo de reprodução do tipo partenogenético têm gerado resultados variáveis a respeito da distância geográfica afetando a diferenciação e distância genética das populações avaliadas. Baumann et al. (2003) estudando a diversidade genética de populações de Diprion pine (L.), um himinópetero praga de pinus em diferentes regiões da Europa, encontraram que as populações coletadas diferiam geneticamente entre as regiões.

Também não se pode desconsiderar a existência de biótipos associados a cada um dos hospedeiros estudados. Trabalhos realizados por Sunnucks et al. (1997) com o afídeo Therioaphis trifolli (Monell) distinguiram dois biótipos deste inseto, cada um associado a um dos hospedeiros alfafa e trevo, na Austrália.

A plasticidade da espécie, no caso de B. phoenicis, deve ser julgada como um efeito gerado ao longo de vários anos de especialização das populações em seus respectivos hospedeiros, uma vez que as populações de B. phoenicis foram coletadas em pomares com 10 a 15 anos de idade e levadas ao laboratório para serem multiplicadas em frutos de laranja para posterior utilização neste trabalho. A deriva genética não deve ser uma das causas da variação encontrada neste estudo devido às populações dos dois hospedeiros terem sido formadas inicialmente por um número grande de indivíduos variando de 150 a 400 e criadas em hospedeiro e condições ambientais iguais (Bartlett, 1984).

Os resultados mostram uma diferenciação genética entre as populações de $B$. phoenicis coletadas em sansão-do-campo e as populações de citros. Porém, estudos futuros devem ser conduzidos para melhor elucidar se estas diferenças são significativas para a infestação de B. phoenicis nos pomares e mesmo como fonte de variabilidade 
genética para as populações de B. phoenicis em citros. No agroecossitema citrícola não se pode desconsiderar a importância de populações de B. phoenicis presentes em plantas hospedeiras no interior e próximas a periferia dos pomares como focos de disseminação do ácaro-da-leprose para os citros e mesmo como fonte de indivíduos suscetíveis para diluir a freqüência da resistência a longo prazo, uma vez que os ácaros destas populações são potencialmente capazes de infestar plantas de citros. 

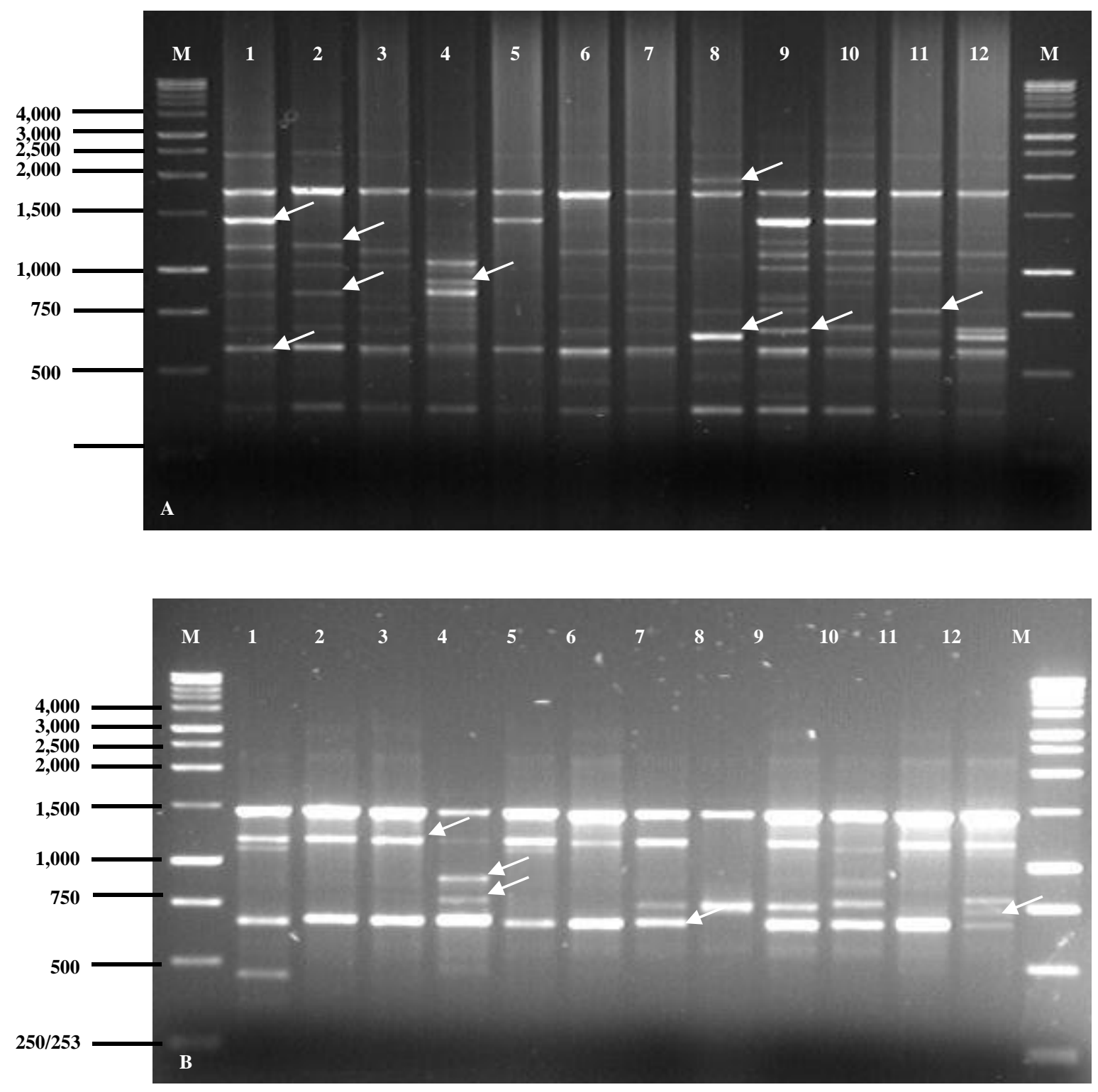

Figura 12A-B - Produtos de PCR de 12 populações de Brevipalpus phoenicis amplificadas com iniciadores randômicos da Operon Technologies. A) Iniciador A5, B) Iniciador C15. Marcador molecular 1kpb ladder $\left(\right.$ Promega $^{\circledR}$ ). Populações de citros e sansão-do-campo, respectivamente, de Boa Esperança do Sul (1 e 2), Gavião Peixoto (3 e 4), Barretos (5 e 6), Onda Verde (7 e 8), Bauru (9 e 10) e Piracicaba (11 e 12). As setas indicam bandas polimórficas 


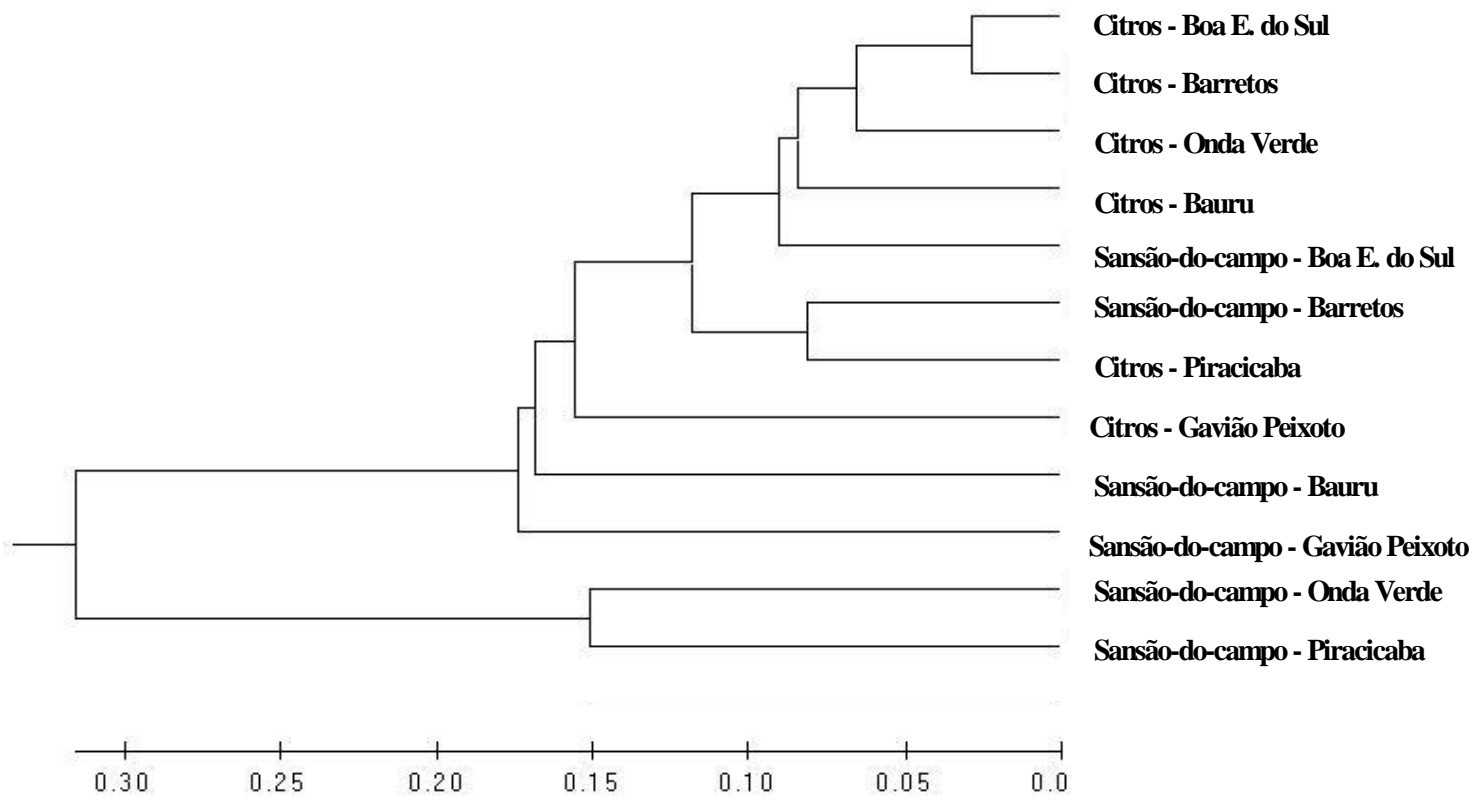

Figura 13 - Dendrograma gerado através do método de UPGMA baseado na distância genética de Nei de doze populações de Brevipalpus phoenicis coletadas em citros (Citrus sinensis) e em sansão-do-campo (Mimosa caesalpiniaefolia), em seis regiões geográficas do Estado de São Paulo 
Tabela 6. Análise multilocus de diversidade gênica para populações de Brevipalpus phoenicis coletadas em citros e sansão-docampo em seis regiões geográficas do Estado de São Paulo. Valores estimados para 61 marcadores RAPD polimórficos

\begin{tabular}{lccc}
\hline \multicolumn{1}{c}{ Hospedeiro } & $\mathbf{H}^{\mathbf{1}}$ & $\mathbf{N}^{\mathbf{0}}$ de loci polimórficos & Proporção de loci polimórficos (\%) \\
\hline Citros & $0,1583(0,1901)$ & 32 & 43,84 \\
Sansão-do-campo & $0,3143(0,1805)$ & 58 & 79,45 \\
\hline
\end{tabular}

${ }^{1} \mathrm{H}=$ diversidade gênica de Nei. Valores entre parênteses representam o desvio padrão

Tabela 7. Análise multilocus de diversidade gênica para populações de Brevipalpus phoenicis coletadas em dois hospedeiros de seis localidades distintas do Estado de São Paulo. Valores estimados para 61 marcadores RAPD polimórficos

\begin{tabular}{lccc}
\hline \multicolumn{1}{c}{ Local } & \multicolumn{1}{c}{$\mathbf{H}^{\mathbf{1}}$} & $\mathbf{N}^{\mathbf{0}}$ de loci polimórficos & Proporção de loci polimórficos (\%) \\
\hline Boa Esperança do Sul & $0,0548(0,1573)$ & 8 & 10,96 \\
Gavião Peixoto & $0,1849(0,2431)$ & 27 & 36,99 \\
Barretos & $0,1096(0,2083)$ & 16 & 21,92 \\
Onda Verde & $0,2808(0,2498)$ & 41 & 56,16 \\
Bauru & $0,0959(0,1982)$ & 14 & 19,18 \\
Piracicaba & $0,1849(0,2431)$ & 27 & 36,99 \\
\hline
\end{tabular}

${ }^{1} \mathrm{H}=$ diversidade gênica de Nei. Valores entre parênteses representam o desvio padrão 
Tabela 8. Análise multi-populacional da diversidade gênica entre as 12 populações de Brevipalpus phoenicis coletadas em dois hospedeiros e provenientes de 6 localidades distintas estimada pela utilização de 61 marcadores RAPD polimórficos. Valores médios de diversidade genética total (Ht), diversidade genética intrapopulação (Hs), coeficiente de diferenciação gênica (Gst), além de número e porcentagem de loci polimórficos para cada sub-população

\begin{tabular}{lccccc}
\hline Sub-população & Ht & Hs & Gst & $\mathbf{N}^{\mathbf{0}}$ de loci polimórficos & \% loci polimórficos \\
\hline Hospedeiros & $0,2776(0,1694)$ & $0,2363(0,0225)$ & 0,1487 & 61 & 83,56 \\
Locais & $0,2776(0,1694)$ & $0,1518(0,0141)$ & 0,4531 & 61 & 83,56 \\
\hline
\end{tabular}


Tabela 9. Identidade genética de (na diagonal acima) e distância genética entre (na diagonal abaixo) 12 populações de Brevipalpus phoenicis coletadas em citros e sansão-do-campo, respectivamente, e provenientes de Boa Esperança do Sul (1 e 2), Gavião Peixoto (3 e 4), Barretos (5 e 6), Onda Verde (7 e 8), Bauru (9 e 10) e Piracicaba (11 e 12)

\begin{tabular}{|c|c|c|c|c|c|c|c|c|c|c|c|c|}
\hline \multirow[b]{2}{*}{ População } & \multicolumn{12}{|c|}{ População } \\
\hline & 1 & 2 & 3 & 4 & 5 & 6 & 7 & 8 & 9 & 10 & 11 & 12 \\
\hline 1 & $=====$ & 0,8904 & 0,7123 & 0,7260 & 0,9452 & 0,7808 & 0,8904 & 0,4658 & 0,8630 & 0,7534 & 0,7945 & 0,5890 \\
\hline 2 & 0,1161 & $=====$ & 0,6849 & 0,8082 & 0,8356 & 0,8356 & 0,8082 & 0,4932 & 0,8082 & 0,6712 & 0,8219 & 0,5616 \\
\hline 3 & 0,3392 & 0,3784 & $=====$ & 0,6301 & 0,7123 & 0,7123 & 0,7671 & 0,5068 & 0,7397 & 0,6849 & 0,8082 & 0,6301 \\
\hline 4 & 0,3202 & 0,2129 & 0,4618 & $=====$ & 0,7260 & 0,7260 & 0,6986 & 0,5753 & 0,6712 & 0,6712 & 0,7123 & 0,5890 \\
\hline 5 & 0,0564 & 0,1796 & 0,3392 & 0,3202 & $=====$ & 0,7808 & 0,8630 & 0,5205 & 0,8082 & 0,7260 & 0,7945 & 0,6164 \\
\hline 6 & 0,2474 & 0,1796 & 0,3392 & 0,3202 & 0,2474 & $====$ & 0,7808 & 0,4932 & 0,7260 & 0,6438 & 0,8493 & 0,5616 \\
\hline 7 & 0,1161 & 0,2129 & 0,2651 & 0,3586 & 0,1473 & 0,2474 & $=====$ & 0,4384 & 0,8630 & 0,7534 & 0,8493 & 0,5890 \\
\hline 8 & 0,7641 & 0,7069 & 0,6795 & 0,5528 & 0,6529 & 0,7069 & 0,8247 & $=====$ & 0,4384 & 0,4384 & 0,4795 & 0,7397 \\
\hline 9 & 0,1473 & 0,2129 & 0,3015 & 0,3986 & 0,2129 & 0,3202 & 0,1473 & 0,8247 & $=====$ & 0,8082 & 0,7397 & 0,5616 \\
\hline 10 & 0,2831 & 0,3986 & 0,3784 & 0,3986 & 0,3202 & 0,4403 & 0,2831 & 0,8247 & 0,2129 & $=====$ & 0,6849 & 0,5342 \\
\hline 11 & 0,2300 & 0,1961 & 0,2129 & 0,3392 & 0,2300 & 0,1633 & 0,1633 & 0,7351 & 0,3015 & 0,3784 & $=====$ & 0,6301 \\
\hline 12 & 0,5293 & 0,5769 & 0,4618 & 0,5293 & 0,4838 & 0,5769 & 0,5293 & 0,3015 & 0,5769 & 0,6269 & 0,4618 & $=====$ \\
\hline
\end{tabular}




\subsection{Considerações Finais}

As estratégias de manejo da resistência são fundamentais para o sucesso dos programas de Manejo Integrado de Pragas (MIP), principalmente em situações onde o uso de produtos químicos é a principal tática para o controle de pragas como é o caso do ácaro-da-leprose Brevipalpus phoenicis na cultura de citros.

Diversos trabalhos básicos para a implementação de estratégias de manejo da resistência de $B$. phoenicis a acaricidas na cultura dos citros já foram desenvolvidos no Brasil. A resistência do ácaro-da-leprose já foi detectada e caracterizada para os principais grupos de acaricidas utilizados na citricultura como dicofol (Alves, 1999; Omoto et al., 2000), hexitiazox (Campos \& Omoto, 2002) e propargite (Franco, 2002). Nos últimos anos, uma maior conscientização com relação à magnitude da resistência no Brasil tem sido observada por parte dos agricultores, dos profissionais ligados à área fitossanitária, seja pública ou privada, e das empresas fabricantes dos defensivos agrícolas, resultando em interesses mútuos para a implementação de estratégias de manejo da resistência. Atualmente alguns citricultores têm adotado estratégias de manejo da resistência envolvendo a rotação de acaricidas que atuam em sítios de ação distintos e adoção de monitoramentos práticos para detecção da resistência a acaricidas.

Porém, um programa de manejo da resistência deve ser dinâmico, ou seja, à medida que novos conhecimentos científicos são elucidados, estes devem ser incorporados para o refinamento das estratégias de manejo da resistência. Desta forma, o presente trabalho objetivou melhorar as estratégias de manejo da resistência de $B$. phoenicis ao acaricida dicofol, através da compreensão da dinâmica da resistência para estimar um intervalo mínimo para o restabelecimento da suscetibilidade para este acaricida e indicar o melhor regime de uso deste produto nos pomares. No entanto, verificou-se que a dinâmica da resistência de $B$. phoenicis ao dicofol é bastante variável de talhão para talhão, sugerindo a necessidade de monitoramento da resistência de $B$. phoenicis ao dicofol por meio de bioensaios práticos, antes da decisão ou não de uso do dicofol em um determinado talhão de citros. 
O custo adaptativo das linhagens resistentes de B. phoenicis ao acaricida dicofol pode ser o principal fator afetando a reversão da resistência a este produto, segundo trabalhos realizados por Alves (1999) e o presente estudo. Embora as plantas hospedeiras de B. phoenicis presentes na periferia do pomar possam atuar como refúgios de populações suscetíveis do ácaro-da-leprose, verificou-se que a dispersão deste ácaro fora e dentro dos pomares é bastante restrita. Os estudos de variabilidade genética através da técnica de RAPD-PCR revelaram um certo isolamento genético das populações de B. phoenicis provenientes de citros em relação à da cerca-viva sansão-docampo Mimosa caesalpiniaefolia. Portanto, a importância das plantas hospedeiras de B. phoenicis nos pomares de citros como fontes de indivíduos suscetíveis para a diluição da resistência deste ácaro nos citros deve ser considerada com bastante cautela. Além disso, o ácaro-da-leprose apresenta reprodução partenogenética do tipo telítoca automítica e a presença de machos é rara na população o que dificultaria a reversão da resistência (Helle et al., 1980; Weeks et al., 2001). 


\section{CONCLUSÕES}

A dinâmica da resistência de Brevipalpus phoenicis (Geijskes) ao acaricida dicofol é bastante variável de talhão para talhão em pomares de citros.

A dispersão de B. phoenicis por caminhamento e pelo vento é bastante limitada.

As freqüências de resistência ao dicofol em populações de B. phoenicis coletadas em cercas-vivas de sansão-do-campo (Mimosa caesalpiniaefolia) são menores do que em populações coletadas em citros no mesmo pomar.

Populações de B. phoenicis coletadas em M. caesalpiniaefolia são geneticamente diferentes das populações coletadas em citros. 
ANEXO 
Anexo A. Histórico de aplicações de acaricidas para o controle de Brevipalpus phoenicis em talhões de citros localizados nas regiões de Araraquara (ARA) e Barretos (BAR)

\begin{tabular}{|c|c|c|c|}
\hline População & Ano & Mês & Produto \\
\hline \multirow{6}{*}{ ARA - 1} & 1998 & $\begin{array}{l}\text { Março } \\
\text { Abril } \\
\text { Junho } \\
\text { Julho }\end{array}$ & $\begin{array}{l}\text { Dicofol } \\
\text { Óxido de fenbutatina } \\
\text { Propargite } \\
\text { Cihexatin + hexitiazox }\end{array}$ \\
\hline & 1999 & Janeiro & Chorfenapyr \\
\hline & 2000 & $\begin{array}{l}\text { Fevereiro } \\
\text { Abril } \\
\text { Agosto }\end{array}$ & $\begin{array}{l}\text { Azocyclotin } \\
\text { Propargite } \\
\text { Calda Sulfocálcica }\end{array}$ \\
\hline & 2001 & $\begin{array}{l}\text { Abril } \\
\text { Julho } \\
\text { Novembro }\end{array}$ & $\begin{array}{l}\text { Dicofol } \\
\text { Cihexatin } \\
\text { Azocyclotin }\end{array}$ \\
\hline & 2002 & Abril & Propargite \\
\hline & 2003 & Janeiro & Óxido de fenbutatina \\
\hline \multirow{4}{*}{ ARA - 2} & 2000 & $\begin{array}{l}\text { Março } \\
\text { Maio } \\
\text { Agosto }\end{array}$ & $\begin{array}{l}\text { Dicofol } \\
\text { Cihexatin } \\
\text { Calda Sulfocálcica }\end{array}$ \\
\hline & 2001 & $\begin{array}{l}\text { Maio } \\
\text { Outubro } \\
\end{array}$ & $\begin{array}{l}\text { Cihexatin } \\
\text { Dicofol }\end{array}$ \\
\hline & 2002 & Março & Propargite \\
\hline & 2003 & $\begin{array}{l}\text { Fevereiro } \\
\text { Junho }\end{array}$ & $\begin{array}{l}\text { Azocyclotin } \\
\text { Propargite }\end{array}$ \\
\hline \multirow{4}{*}{ ARA - 3} & 2000 & $\begin{array}{l}\text { Janeiro } \\
\text { Maio } \\
\text { Agosto }\end{array}$ & $\begin{array}{l}\text { Dicofol } \\
\text { Propargite } \\
\text { Calda sulfocálcica }\end{array}$ \\
\hline & 2001 & $\begin{array}{l}\text { Janeiro } \\
\text { Abril } \\
\text { Junho } \\
\text { Outubro } \\
\end{array}$ & $\begin{array}{l}\text { Cihexatin } \\
\text { Azocyclotin } \\
\text { Calda Sulfocálcica } \\
\text { Propargite }\end{array}$ \\
\hline & 2002 & $\begin{array}{l}\text { Fevereiro } \\
\text { Maio } \\
\text { Dezembro }\end{array}$ & $\begin{array}{l}\text { Azocyclotin } \\
\text { Propargite } \\
\text { Óxido de fenbutatina }\end{array}$ \\
\hline & 2003 & Abril & Propargite \\
\hline
\end{tabular}


Anexo A. Histórico de aplicações de acaricidas para o controle de Brevipalpus phoenicis em talhões de citros localizados nas regiões de Araraquara (ARA) e Barretos (BAR)

\begin{tabular}{|c|c|c|c|}
\hline População & Ano & Mês & Produto \\
\hline \multirow{4}{*}{ ARA - 4} & 2000 & $\begin{array}{l}\text { Março } \\
\text { Maio } \\
\text { Agosto }\end{array}$ & $\begin{array}{l}\text { Dicofol } \\
\text { Cihexatin } \\
\text { Calda Sulfocálcica }\end{array}$ \\
\hline & 2001 & $\begin{array}{l}\text { Maio } \\
\text { Outubro }\end{array}$ & $\begin{array}{l}\text { Cihexatin } \\
\text { Azocyclotin }\end{array}$ \\
\hline & 2002 & Março & Propargite \\
\hline & 2003 & $\begin{array}{l}\text { Fevereiro } \\
\text { Junho }\end{array}$ & $\begin{array}{l}\text { Azocyclotin } \\
\text { Propargite }\end{array}$ \\
\hline \multirow{4}{*}{ BAR - 1} & 2000 & $\begin{array}{l}\text { Janeiro } \\
\text { Abril } \\
\text { Novembro }\end{array}$ & $\begin{array}{l}\text { Dicofol } \\
\text { Cihexatin } \\
\text { Propargite }\end{array}$ \\
\hline & 2001 & $\begin{array}{l}\text { Junho } \\
\text { Novembro }\end{array}$ & $\begin{array}{l}\text { Azocyclotin } \\
\text { Dicofol }\end{array}$ \\
\hline & 2002 & $\begin{array}{l}\text { Março } \\
\text { Julho }\end{array}$ & $\begin{array}{l}\text { Azocyclotin } \\
\text { Cihexatin }\end{array}$ \\
\hline & 2003 & $\begin{array}{l}\text { Fevereiro } \\
\text { Junho }\end{array}$ & $\begin{array}{l}\text { Propargite } \\
\text { Azocyclotin + Cihexatin }\end{array}$ \\
\hline \multirow{4}{*}{ BAR - 2} & 2000 & $\begin{array}{l}\text { Fevereiro } \\
\text { Junho } \\
\text { Setembro } \\
\text { Novembro }\end{array}$ & $\begin{array}{l}\text { Dicofol } \\
\text { Calda sulfocálcica } \\
\text { Cihexatin } \\
\text { Propargite }\end{array}$ \\
\hline & 2001 & $\begin{array}{l}\text { Março } \\
\text { Junho } \\
\text { Outubro }\end{array}$ & $\begin{array}{l}\text { Dicofol } \\
\text { Calda sulfocálcica } \\
\text { Azocyclotin }\end{array}$ \\
\hline & 2002 & $\begin{array}{l}\text { Janeiro } \\
\text { abril } \\
\text { Novembro }\end{array}$ & $\begin{array}{l}\text { Propargite } \\
\text { Azocyclotin } \\
\text { Azocyclotin }\end{array}$ \\
\hline & 2003 & março & Propargite \\
\hline
\end{tabular}


Anexo A. Histórico de aplicações de acaricidas para o controle de Brevipalpus phoenicis em talhões de citros localizados nas regiões de Araraquara (ARA) e Barretos (BAR)

\begin{tabular}{|c|c|c|c|}
\hline População & Ano & Mês & Produto \\
\hline \multirow{4}{*}{ BAR - 3} & 2000 & $\begin{array}{l}\text { Março } \\
\text { Junho } \\
\text { Novembro }\end{array}$ & $\begin{array}{l}\text { Dicofol } \\
\text { Calda Sulfocálcica } \\
\text { Azocyclotin }\end{array}$ \\
\hline & 2001 & $\begin{array}{l}\text { Fevereiro } \\
\text { Maio }\end{array}$ & $\begin{array}{l}\text { Cihexatin } \\
\text { Cihexatin }\end{array}$ \\
\hline & 2002 & $\begin{array}{l}\text { Abril } \\
\text { Outubro }\end{array}$ & $\begin{array}{l}\text { Propargite } \\
\text { Azocyclotin }\end{array}$ \\
\hline & 2003 & Março & Azocyclotin \\
\hline \multirow{5}{*}{ BAR - 4} & 1999 & $\begin{array}{l}\text { Fevereiro } \\
\text { Setembro }\end{array}$ & $\begin{array}{l}\text { Azocyclotin } \\
\text { Dicofol }\end{array}$ \\
\hline & 2000 & $\begin{array}{l}\text { Janeiro } \\
\text { Julho } \\
\text { Novembro }\end{array}$ & $\begin{array}{l}\text { Hexitiazox } \\
\text { Calda sulfocálcica } \\
\text { Propargite }\end{array}$ \\
\hline & 2001 & $\begin{array}{l}\text { Fevereiro } \\
\text { Maio } \\
\text { Novembro }\end{array}$ & $\begin{array}{l}\text { Cihexatin } \\
\text { Calda sulfocálcica } \\
\text { Propargite }\end{array}$ \\
\hline & 2002 & $\begin{array}{l}\text { Maio } \\
\text { Novembro }\end{array}$ & $\begin{array}{l}\text { Azocyclotin } \\
\text { Óxido de fenbutatina }\end{array}$ \\
\hline & 2003 & Marco & Azocyclotin \\
\hline
\end{tabular}




\section{REFERÊNCIAS BIBLIOGRÁFICAS}

ALVES, E. B. Manejo da resistência do ácaro da leprose Brevipalpus phoenicis (Geijskes, 1939) (Acari: Tenuipalpidae) ao acaricida dicofol. Piracicaba, 1999. 91p. Dissertação (Mestrado) - Escola Superior de Agricultura "Luiz de Queiroz", Universidade de São Paulo.

ALVES, E. B.; OMOTO, C.; FRANCO, C. R. Resistência cruzada entre o dicofol e outros acaricidas em Brevipalpus phoenicis (Geijskes) (Acari: Tenuipalpidae). Anais da Sociedade Entomológica do Brasil, v.29, n.4, p.765-771, dez. 2000a.

ALVES, E. B.; OMOTO, C.; FRANCO, C. R. Mistura de dicofol com fempiroximato no manejo da resistência de Brevipalpus phoenicis (Geijskes) (Acari: Tenuipalpidae) ao dicofol. Anais da Sociedade Entomológica do Brasil, v.29, n.4, p.789-797, dez. 2000b.

ALVES, E. B.; RIBEIRO, P. C.; CAMPOS, F. J. et al. A resistência do ácaro da leprose (Brevipalpus phoenicis) ao dicofol pode ser manejada? In: CONGRESSO BRASILEIRO DE ENTOMOLOGIA, 17., Rio de Janeiro, 1998. Resumos. Rio de Janeiro: SEB, 1998. v.2, p.1048.

ALVES, S. B.; LOPES, R. B.; TAMAI, M. A. et al. Compatibilidade de produtos fitossanitários com entomopatógenos em citros. Laranja, v.21, n.2, p.289-294, 2000c. 
BARTLETT, A. C. Genetic changes during insect domestication. In: KING, E. G.; LEPPLA, N. C. (ed.). Advances and challenges in insect rearing. Washington: USDA, ARS, 1984. p.2-8.

BAUMANN, R.; SCHUBERT, R.; HEITLAND, W. et al. Genetic diversity within and among populations of Diprion pine (Hym., Diprionidae) determined by random amplified polymorphic DNA-polymerase chain reaction of haploid males. Journal of Applied Entomology, v.127, p.258-264, 2003.

BENTO, J. M. S.; VILELA, E. F.; PARRA, J. R. P. et al. Monitoramento do bichofurão-dos-citros com feromônio sexual: Bases comportamentais para utilização dessa nova estratégia. Laranja, v.22, n.2, p.351-366, 2001.

BERGH, J. C. Ecology and aerobiology of dispersing citrus rust mites (Acari: Eriophyidae) in central Florida. Environmental Entomology, v.30, n.2, p.318-326, Apr. 2001.

BERGH, J. C.; McCOY, C. W. Aerial dispersal of citrus rust mite (Acari: Eriophyidae) from Florida citrus groves. Environmental Entomology, v.26, n.2, p.256-264, 1997.

BERNSTEIN, C. Some aspects of Phytoseiulus persimilis (Acarina: Phytoseiidae) dispersal behaviour. Entomophaga, v.28, n.2, p.185-198, 1983.

BILLS, P. S.; MOTA-SANCHEZ, D.; WHALON, M. The database of arthropods resistant to pesticides. Michigan State University. http://www.cips.msu.edu/resistance/rmdb (14 Jan. 2004). 
BRANDENBURG, R. L.; KENNEDY, G. G. Intercrop relationships and spider mite dispersal in a corn/peanut agro-ecosystem. Entomologia Experimentalis \& Applicata, v.32, p.269-276, 1982.

CAMPOS, F.; OMOTO, C. Resistance to hexythiazox in Brevipalpus phoenicis (Acari: Tenuipalpidae) from Brazilian citrus. Experimental and Applied Acarology, v.26, p.243-251, 2002.

CHAGAS, M. C. M.; PARRA, J. R. P.; MILANO, P. et al. Ageniaspis citricola: Criação e estabelecimento no Brasil. In: PARRA, J. R. P.; BOTELLO, P. S. M.; CORRÊA-FERREIRA, B. S.; BENTO, J. M. S. (Ed.) Controle Biológico no Brasil: Parasitóides e Predadores. São Paulo: Manole, 2002, cap. 23, p.377-394.

CHIAVEGATO, L. G. Bioecologia do ácaro da leprose Brevipalpus phoenicis (Geijskes, 1939) (Acari: Tenuipalpidae) em citros. In: CONGRESSO BRASILEIRO DE ENTOMOLOGIA, 10., Rio de Janeiro, 1986. Resumos. Rio de Janeiro: SEB, 1986. p.35.

CHIAVEGATO, L. G. A leprose dos citros no Estado de São Paulo. Laranja, v. 8, n.1, p.7-18, dez. 1987.

CHIAVEGATO, L. G.; MISCHAN, M. M. Comportamento do ácaro Brevipalpus phoenicis (Geijskes, 1939) (Acari: Tenuipalpidae) em frutos de diferentes variedades cítricas. Científica, v.15, n.1/2, p.17-22, 1987.

CHILDERS, C. C.; KITAJIMA, E. W.; WELBOURN, W. C. et al. Brevipalpus phoenicis mites on citrus and their status as vectors of citrus leprosis. Manejo Integrado de Plagas, v. 60, p.66-70, 2001. 
COLETTA-FILHO, H. D.; MACHADO, M. A. Evaluation of the genetic structure of Xylella fastidiosa populations from diferent Citrus sinensis varietis. Applied and Environmental Microbiology, v.68, n.8, p.3731-3736. Aug. 2002.

COMEnAle NetO, C.; YAMAMOTO, T.; GRAVENA, S. et al. Período de controle do ácaro da leprose Brevipalpus phoenicis por acaricidas em diferentes níveis de infestação. Laranja, v.16, n.2, p.251-261, 1995.

COMINS, H. N. Tactics for resistance management using multiple pesticides. Agriculture, Ecosystems and Environment, v.16, p.129-148, 1986.

DENNEHY, T. J.; GRANETT, J. Monitoring dicofol-resistant spider mites (Acari: Tetranychidae) in California Cotton. Journal of Economic Entomology, v.77, n.6, p.1386-1392, Dec. 1984a.

DENNEHY, T. J.; GRANETT, J. Spider mite resistance to dicofol in San Joaquin Valley Cotton: inter- and intraspecific variability in susceptibility of three species of Tetranychus (Acari: Tetranychidae). Journal of Economic Entomology, v.77, n.6, p.1381-1385, Dec. 1984b.

DENNEHY, T. J.; NYROP, J. P.; REISSIG, W. H. et al. Characterization of resistance to dicofol in spider mites (Acari: Tetranychidae) from New York apple orchards. Journal of Economic Entomology, v.81, n.6, p.1551-1561, Dec. 1988.

DENNEHY, T. J.; NYROP, J. P.; MARTINSON, T. E. Caracterization and exploitation of instability of spider mite resistance to acaricides. In: GREEN, M. B.; LeBARON, H. M.; MOBERG, W. K. (Ed.) Managing resistance to agrochemicals: from fundamental research to practical strategies. Washington: American Chemical Society, 1990. cap.5, p. 77-91. 
DENNEHY, T. J.; OMOTO, C. Sustaining the efficacy of dicofol against citrus rust mite (Phyllocoptruta oleviora): a case-history of industrial and academic collaboration. Brighton Crop Protection Conference - Pests and Diseases, p.955-962, 1994.

DUNCOMBE, W. G. The acaricide spray rotation for cotton. Rhodesia Agricultural Journal, v.70, n.5, p.115-118, 1973.

DUNLEY, J. E.; CROFT, B. A. Dispersal and gene flow of pesticide resistance traits in phytoseiid and tetranychid mites. Experimental and Applied Acarology, v.14, p.313-325, 1992.

DURIGAN, J. C. A importância das plantas daninhas no manejo integrado de pragas da cultura de citros. In: SEMINÁRIO INTERNACIONAL DE CITROS-MIP, 3., Bebedouro, 1994. Manejo integrado de pragas dos citros, anais. Campinas: Fundação Cargill, 1994. p.277-290.

EXCOFFIER, L.; SMOUSE, P. E.; QUATTRO, J. M. Analysis of molecular variance inferred from metric distances among DNA haplotypes: Application to Human Mitochondrial DNA restriction data. Genetics, v.131, p.479-491, Jun. 1992.

FERGUSSON-KOLMES, L. A.; SCOTT, J. G.; DENNEHY, T. J. Dicofol resistance in Tetranychus urticae (Acari: Tetranychidae): cross-resistance and pharmacokinetics. Journal of Economic Entomology, v.84, n.1, p.41-48, Feb. 1991.

FNP CONSULTORIA \& COMÉRCIO. AGRIANUAL 2003: anuário estatístico da agricultura brasileira. São Paulo, 2003. p.295-314: Citros. 
FORRESTER, N. W. Designing, implementing and servicing an insecticide resistance management strategy. Pesticide Science, v.28, p.167-179, 1990.

FRANCO, C. R. Detecção e caracterização da resistência de Brevipalpus phoenicis (Geijskes, 1939) (Acari: Tenuipalpidae) a acaricida propargite. Piracicaba, 2002. 64p. Dissertação (Mestrado) - Escola Superior de Agricultura "Luiz de Queiroz", Universidade de São Paulo.

FUTUYMA, D. J. Biologia evolutiva. Ribeirão Preto: Sociedade Brasileira de Genética/CNPq, 1992, 642p.

GEORGHIOU, G. P. Management of resistance in arthropods. In: GEORGHIOU, G. P.; SAITO, T. (Ed.). Pest resistance to pesticides. New York: Plenum, 1983. p.769-792.

GEORGHIOU, G. P. The magnitude of the resistance problem. In: NATIONAL RESEARCH COUNCIL. Pesticide resistance: strategies and tactics for management. Washington: National Academy Press, 1986. p.14-43.

GEORGHIOU, G. P.; TAYLOR, C.E. Genetic and biological influences in the evolution of isecticide resistance. Journal of Economic Entomology, v.70, n.3, p.319-323, Jun. 1977a.

GEORGHIOU, G. P.; TAYLOR, C.E. Operational influences in the evolution of insecticide resistance. Journal of Economic Entomology, v.70, n.5, p. 653-658, Oct. 1977b.

GEORGHIOU, G. P.; TEJADA, A. L. The ocurrence of resistance to pesticides in arthropods. Rome: FAO, 1991. 318 p. 
GERSON, U. Webbing. In: HELLE. W.; SABELIS, M. W. (Ed.) Spider mites: their biology, natural enemies and control. New York: Elsevier, 1985. p.223-232. (World Crop Pests, 1A).

GRAFTON-CARDWELL, E. E.; GRANETT J.; NORMINGTON, S. M. Influence of dispersal from almonds on the population dynamics and acaricide resistance frequencies of spider mites infesting neighboring cotton. Experimental and Applied Acarology, v.10, p.187-212, 1991.

GRAVENA, S. Rotação de acaricidas no MIP-Citros: menos desequilíbrio e resistência. Laranja, v.15, n.2, p.375-395, 1994.

GUIRADO, N.; SILVERIO, J. L. Leprose e declínio: Problemas sérios da citricultura paulista. Laranja, v.13, n.2, p.541-552, 1992.

HARAMOTO, F. H. Biology and control of Brevipalpus phoenicis (Geijskes) (Acarina: Tenuipalpidae). Hawaii Agricultural Experimental Station Technical Bulletin, n.68, p.1-63, Dec. 1969.

HELLE, W.; P; BOLLAND, H. R.; HEITMANS, W. R. B. Chromosomes and types of parthenogenesis in the false spider mites (Acari: Tenuipalpidae). Genetica, v.54, p.45-50, 1980.

HERNE, D. C.; CHIBA, M. Mortality of the european red mite (Acarina: Tetranychidae) relative to distribution and degradation of dicofol deposits on peach leaves. Canadian Entomologist, v.107, p.801-806, Aug. 1975.

HOY, M. A.; VAN DE BAAN, H. E.; GROOT, J. J. R. et al. Aerial movements of mites in almonds: implications for pest management. California Agriculture, v.38, n.9, p.21-23, Sept. 1984. 
INOUE, K. Relationship between dicofol resistance and fitness in the citrus red mite, Panonychus citri (McG.). Journal of Pesticide Science, v.5, p.165-175, 1980.

KENNEDY, G. G.; SMITLEY, D. R. Dispersal. In: HELLE. W.; SABELIS, M. W. (Ed.). Spider mites: their biology, natural enemies and control. New York: Elsevier, 1985. p.233-242. (World Crop Pests, 1A).

KENNEDY, J. S.; VanIMPE, G; HANCE, TH. et al. Demecology of the false spider mite, Brevipalpus phoenicis (Geijskes) (Acari: Tenuipalpidae). Journal of Applied Entomology, v.120, p.493-499, 1996.

KITAJIMA, E. W.; MÜLLER, G. W.; COSTA, A. S. et al. Short, rod-like particles associated with citrus leprosis. Virology, v.50, n.1, p.254-258, Oct. 1972.

LAWSON, D. S.; NYROP, J. P.; DENNEHY, T. J. Aerial dispersal of european red mites (Acari: Tetranychidae) in commercial apple orchards. Experimental \& Applied Acarology, v.20, p.193-202, 1996.

LEAL, W. S.; BENTO, J. M. S.; MURATA, Y. et al. Identification, synthesis, and field evaluation of the sex pheromone of the citrus fruit borer. Journal of Chemical Ecology, v.27, n.10, p.2041-2051, Oct. 2001.

MABLE, B. K.; PREE, D. J. Stability of dicofol resistance in populations of european red mite (Acari: Tetranychidae) on apples in Southern Ontario. Journal of Economic Entomology, v.85, n.3, p.642-650, Jun. 1992.

MAIA, O. M. A.; OLIVEIRA, C. A. L. Capacidade de colonização de Brevipalpus phoenicis (Geijskes, 1939) (Acari: Tenuipalpidae) em cercas-vivas, quebra-ventos e plantas daninhas. In: CONGRESSO BRASILEIRO DE ENTOMOLOGIA, 19., Manaus, 2002. Resumos. Manaus: INPA, 2002. p.249. 
MANI, G. S. Evolution of resistance in the presence of two insecticides. Genetics, v.109, p.761-783, Apr. 1985.

MILLER, R. W.; CROFT, B. A.; NELSON, R. D. Effects of early season immigration on cyhexatin and formetanate resistance of Tetranychus urticae (Acari: Tetranychidae) on strawberry in central California. Journal of Economic Entomology, v.78, n.6, p.1379-1388, Dec. 1985.

McKENZIE, J. A. Ecological and evolutionary aspects of insecticide resistance. Austin: R. G. Landes Company; Academic Press, 1996. 185p.

NAKANO, O. ; SANCHES, G. A.; ISHIDA, A. K. Redução da infestação do ácaro da leprose Brevipalpus phoenicis (Geijskes, 1939) em citros através do controle da verrugose. Laranja, v.8, n.1, p.19-33, dez. 1987.

NATIONAL RESEARCH COUNCIL. Pesticide resistance: strategies and tactics for management. Washington, DC: National Academy Press, 1986. 471p.

NAULT, L. R.; STYER, W. E. The dispersal of Aceria tulipae and three other grassinfesting eriophyid mites in Ohio. Annals of the Entomological Society of America, v.62, p.1446-1455, Nov. 1969.

NAVAJAS, M. Host plant associations in the spider mite Tetranychus urticae (Acari: Tetranychidae): insights from molecular phylogeography. Experimental \& Applied Acarology, v.22, n.4, p.201-214, Apr. 1998.

NEI, M. Analysis of gene diversity in subdivided populations. Proceedings of the National Academy of Science, USA, v.70, p.3321-3323, 1973. 
NEVES, E. M.; DAYOUB, M.; DRAGONE, D. S. Demanda por fatores de produção na citricultura: Fertilizantes e defensivos agrícolas. Laranja, v.23, n.1, p.37-56, 2002.

OMOTO, C. Manejo da resistência de ácaros e insetos aos produtos químicos na citricultura. Laranja, v.16, n.1, p.187-208, 1995.

OMOTO, C. Acaricide resistance management of leprosis mite (Brevipalpus phoenicis) in brazilian citrus. Pesticide Science, v.52, p.189-198, 1998.

OMOTO, C.; DENNEHY, T. J.; McCOY, C. W. et al. Detection and characterization of the interpopulation variation of citrus rust mite (Acari: Eriophyidae) resistance to dicofol in Florida citrus. Journal of Economic Entomology, v.87, n.3, p.566-572, Jun. 1994.

OMOTO, C.; DENNEHY, T. J.; McCOY, C. W. et al. Management of citrus rust mite (Acari: Eriophyidae) resistance to dicofol in Florida citrus. Journal of Economic Entomology, v.88, n.5, p.1120-1128. Oct. 1995.

OMOTO, C.; ALVES, E. B.; RIBEIRO, P. C. Detecção e monitoramento da resistência de Brevipalpus phoenicis (Geijskes) (Acari: Tenuipalpidae) ao dicofol. Anais da Sociedade Entomológica do Brasil, v.29, n. 4, p.757-764, dez. 2000.

OVERMEER, W. P. J.; VAN ZON, A. Q.; HELLE, W. The stability of acaricide resistance in spider mite (Tetranychus urticae) populations from rose houses. Entomologia Experimentalis \& Applicata, v.18, p.68-74, 1975.

PIJNACKER, L. P.; FERWERDA, M. A.; BOLLAND, H. R. et al. Haploid female parthenogenesis in the false spider mite Brevipalpus obovatus (Acari: Tenuipalpidae). Genetica, v.51, n.3, p.211-214, 1980. 
PITELLI, R. A.; DURIGAN, J. C. Manejo de plantas daninhas e controle do ácaro da leprose. In: OLIVEIRA, C. A. L. de; DONADIO, L. C. (Ed.) Leprose dos citros. Jaboticabal: FUNEP, 1995. p.171-178.

POLETTI, M. Variabilidades inter e intraespecífica na suscetibilidade de ácaros fitoseídeos (Acari: Phytoseiidae) a dicofol e deltametrina em citros. Piracicaba, 2002. 78p. Dissertação (Mestrado) - Escola Superior de Agricultura "Luiz de Queiroz”, Universidade de São Paulo.

PUTERKA, G. J.; BLACK, W. C.; STEINER, W. M. et al. Genetic variation and phylogenetic relationships among worldwide collections of the russian wheat aphid, Diuraphis noxia (Mordvilko), inferred from allozyme and RAPD - PCR markers. Heredity, v.70, p.604-618, 1993.

\section{REIS, P. R. Ácaros de algumas fruteiras de clima tropical e subtropical e seus} hospedeiros. Lavras: ESAL, 1974, 32p. (Boletim Técnico, Série Pesquisa, 3).

REIS, P. R.; ChIAVEGAtO, L. G.; MORAES, G. J. et al. Seletividade de agroquímicos ao ácaro predador Iphiseiodes zuluagai Denmark \& Muma (Acari: Phytoseiidae). Anais da Sociedade Entomológica do Brasil, v.27, n.2, p.265-274, jun. 1998.

RODRIGUES, J. C. V. Relações patógeno-vetor-planta no sistema leprose dos citros. Piracicaba, 2000. 168 p. Tese (Doutorado) - Centro de Energia Nuclear na Agricultura, Universidade de São Paulo.

RODRIGUES, J. C. V. Programa de redução do inóculo da leprose dos citros. Laranja, v.23, n.2, p.321-332, 2002. 
RODRIGUES, J. C. V.; KITAJIMA, E. W.; CHILDERS, C. C. et al. Citrus leprosis virus vectored by Brevipalpus phoenicis (Acari: Tenuipalpidae) on citrus in Brazil. Experimental and Applied Acarology, v.30, p.161-179, 2003.

ROUSH, R. T.; DALY, J. C. The role of population genetics in resistance research and management. In: ROUSH, R. T.; TABASHNIK, B. E. (Ed.) Pesticide resistance in arthropods. New York: Chapman and Hall, 1990. cap. 5, p.97-152.

ROUSH, R. T.; McKENZIE, J. A. Ecological genetics of insecticide and acaricide resistance. Annual Review of Entomology, v.32, p.361-380, 1987.

SALVA, R. A. Prática do monitoramento do MIP-Citros no Brasil. In: SEMINÁRIO INTERNACIONAL DE CITROS-MIP, 3., Bebedouro, 1994. Manejo integrado de pragas dos citros, anais. Campinas: Fundação Cargill, 1994. p.255-268.

SALVA, R. A.; MASSARI, C. A. Situação do ácaro da leprose no Estado de São Paulo (Levantamento-Fundecitrus Agosto 1995). In: OLIVEIRA, C. A. L. de; DONADIO, L. C. (Ed.) Leprose dos citros. Jaboticabal: FUNEP, 1995. p.13-18.

SALVO FILHO, A. de. Notas sobre o tratamento fitossanitário em citros. Laranja, v.18, n.1, p.155-163, 1997.

SAWICKI, R. M.; DENHOLM, I. Management of resistance to pesticides in cotton pests. Tropical pest management, v.33, n.4, p.262-272, 1987.

SILVEIRA NETO, S.; NAKANO, O.; BARBIN, D. et al. Manual de ecologia dos insetos. São Paulo: Ceres, 1976. 419p.

SLYKHUIS, J. T. Aceria tulipae Keifer (Acarina: Eriophyidae) in relation to the spread of wheat streak mosaic. Phytopathology, v.45, p.116-128, Mar. 1955. 
SUNNUCKS, P.; DRIVER, F.; BROWN, W. V. et al. Biological and genetic characterization of morphologically similar Therioaphis trifolii (Hemiptera: Aphididae) with different host utilization. Bulletin of Entomological Research, v.87, p.425-436, 1997.

TABASHNIK, B. E. Managing resistance with multiple pesticide tactics: theory, evidence, and recommendations. Journal of Economic Entomology, v.82, n.5, p.1263-1269, Oct. 1989.

TABASHNIK, B. E.; CROFT, B. A. Managing pesticide resistance in crop-arthropod complexes: Interactions between biological and operational factors. Environmental Entomology, v.11, n.6, p.1137-1144, 1982.

TAYLOR, C. E.; GEORGHIOU, G. P. Influence of pesticide persistence in evolution of resistance. Environmental Entomology, v.11, n.3, p.746-750, Jun. 1982.

TRINDADE, M. L. B.; CHIAVEGATO, L. G. Caracterização biológica dos ácaros Brevipalpus obovatus D., B. californicus B. e B. phoenicis G. (ACARI: TENUIPALPIDAE). Anais da Sociedade Entomológica do Brasil, v.23, n.2, p.189-195, 1994.

WASHBURN, J. O.; WASHBURN, L. Active aerial dispersal of minute wingless arthropods: exploitation of boundary-layer velocity gradients. Science, v.223, p.1088-1089, Mar. 1984.

WEEKS, A. R.; MAREC, F.; BREEUWER, J. A. J. A mite species that consists entirely of haploid females. Science, v.292, p.2479-2482, Jun. 2001. 